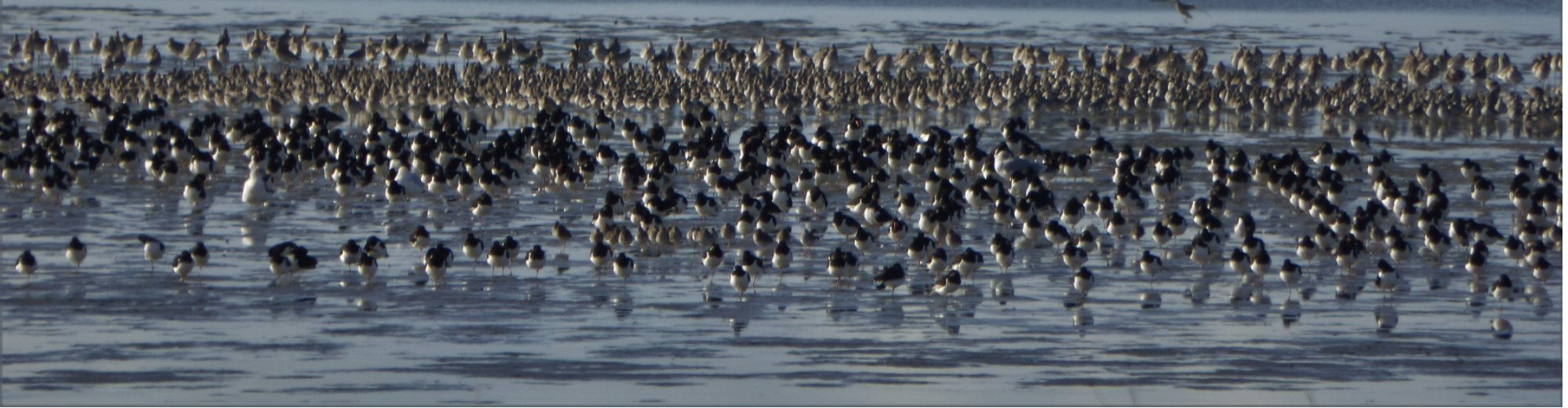

\title{
Trends van steltlopers en andere benthos etende vogels in de Oosterschelde: 1987 - 2017/2018
}




\section{Trends van steltlopers en andere benthos etende vogels in de Oosterschelde: 1987 - $2017 / 2018$}

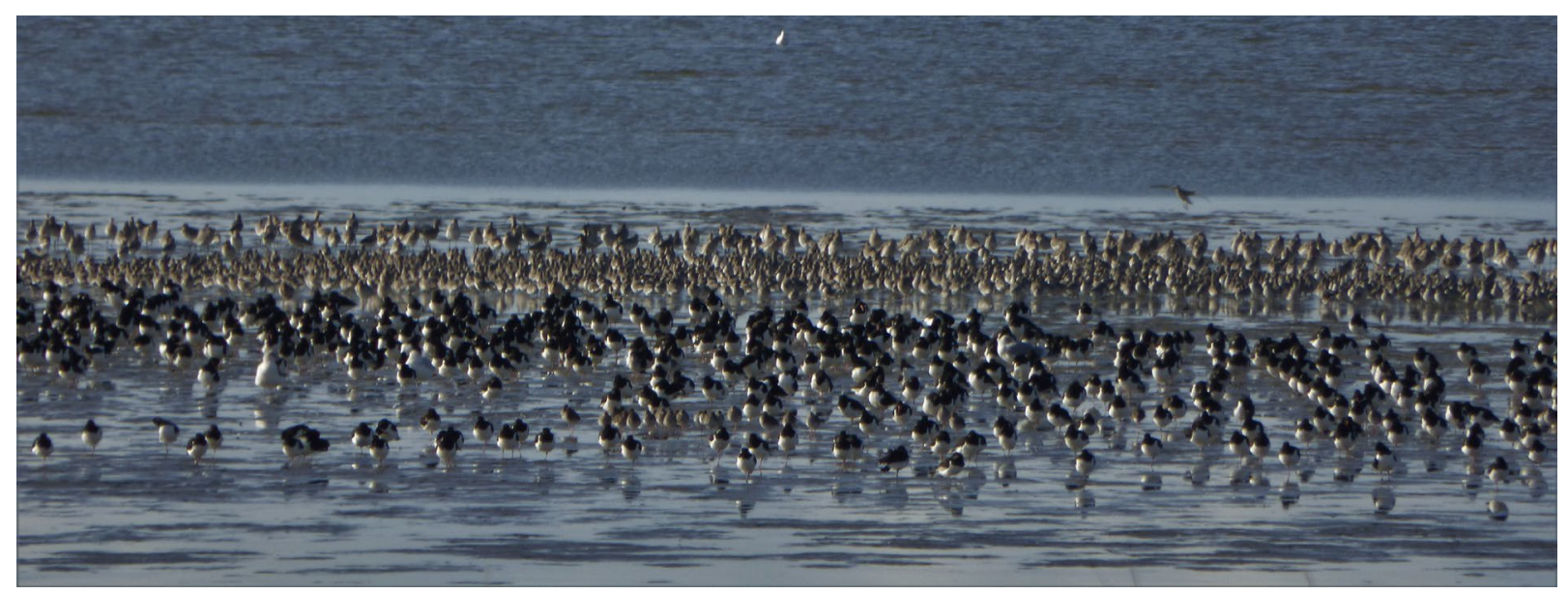


Keywords: steltlopers, trends, Oosterschelde, benthos etende vogels

Opdrachtgever: Ministerie van Landbouw, Natuur en Voedselkwaliteit

T.a.v.: Jip van Peijpe

Bezoudenhoutseweg 73

2594 AC Den Haag

BO-43-021.03-001

Dit rapport is gratis te downloaden van https://doi.org/10.18174/537451

Wageningen Marine Research verstrekt geen gedrukte exemplaren van rapporten.

Wageningen Marine Research is ISO 9001:2015 gecertificeerd.

Foto omslag: Susanne van Donk

(c) Wageningen Marine Research

Wageningen Marine Research, instituut binnen de rechtspersoon Stichting

Wageningen Research, hierbij

vertegenwoordigd door

Dr. ir. J.T. Dijkman, Managing director

KvK nr. 09098104,

WMR BTW nr. NL 8113.83.696.B16.

Code BIC/SWIFT address: RABONL2U

IBAN code: NL 73 RABO 0373599285
Wageningen Marine Research aanvaardt geen aansprakelijkheid voor gevolgschade, noch voor schade welke voortvloeit uit toepassingen van de resultaten van werkzaamheden of andere gegevens verkregen van Wageningen Marine Research. Opdrachtgever vrijwaart Wageningen Marine Research van aanspraken van derden in verband met deze toepassing.

Alle rechten voorbehouden. Niets uit deze uitgave mag weergegeven en/of gepubliceerd worden, gefotokopieerd of op enige andere manier gebruikt worden zonder schriftelijke toestemming van de uitgever of auteur. 


\section{Inhoud}

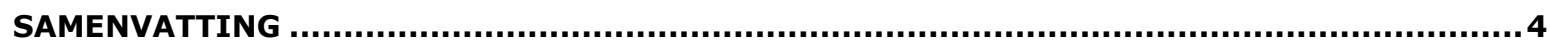

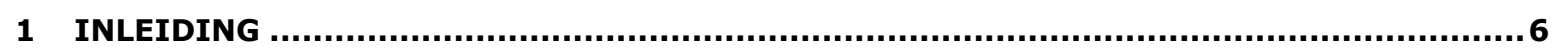

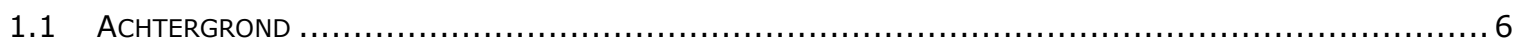

1.1.1 Belang zuidwestelijke Delta en Oosterschelde voor watervogels ...........................6 6

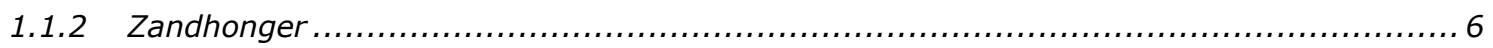

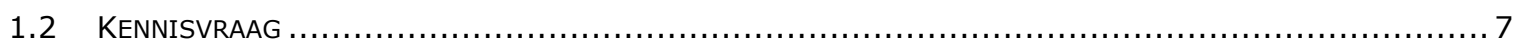

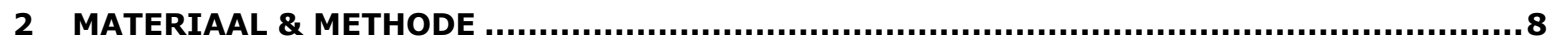

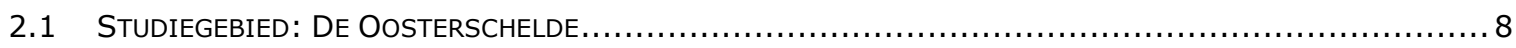

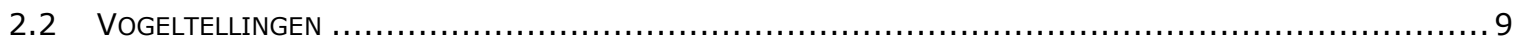

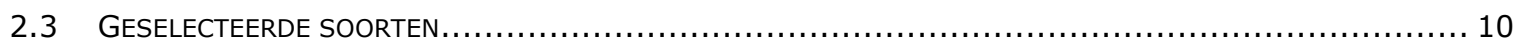

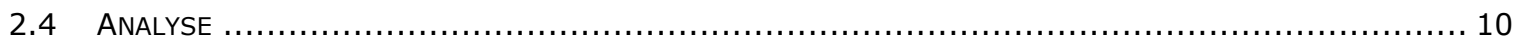

2.4.1 Gebruik tellingen Oosterschelde en deelgebieden...................................... 10

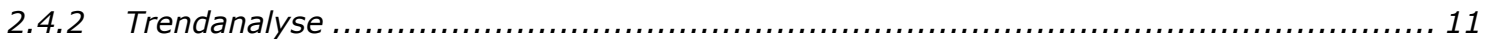

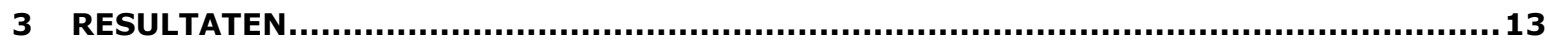

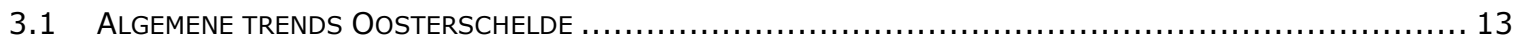

3.1.1 Absolute aantal vogels over de tijd ................................................ 13

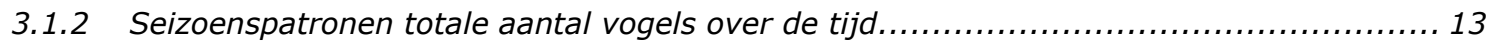

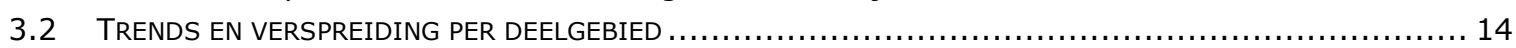

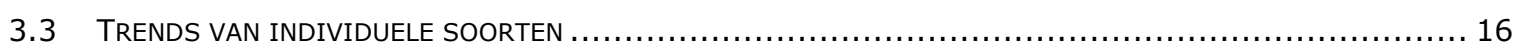

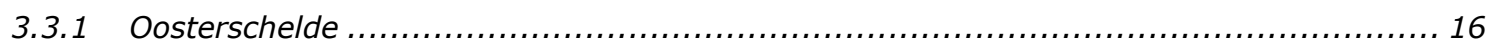

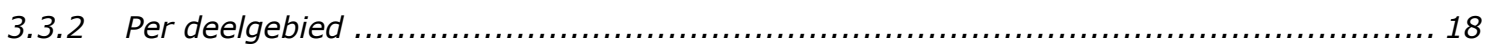

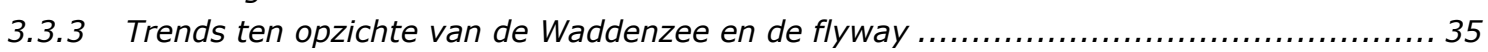

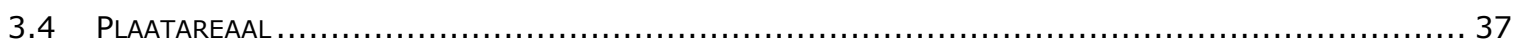

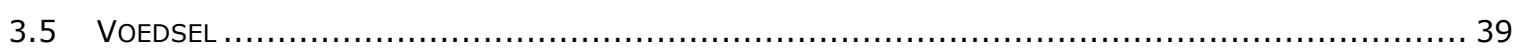

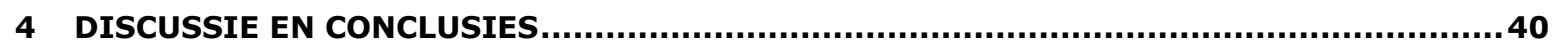

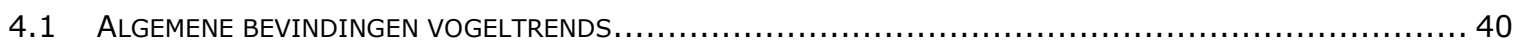

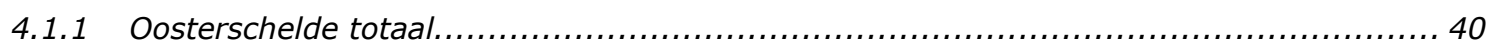

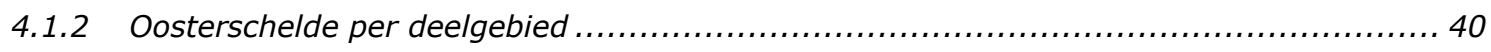

4.1.3 Oosterschelde ten opzichte van de Waddenzee en flyway...............................4 41

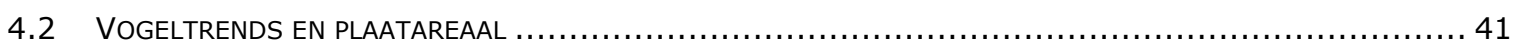

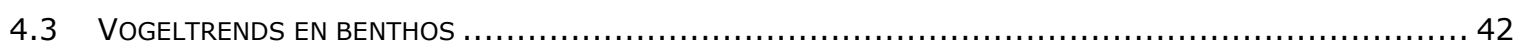

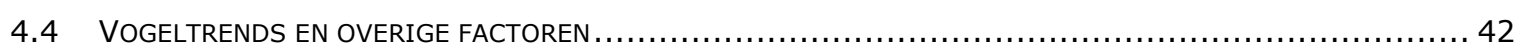

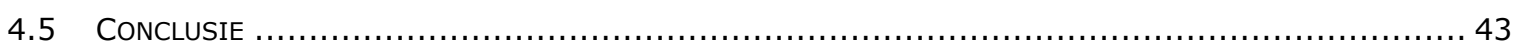

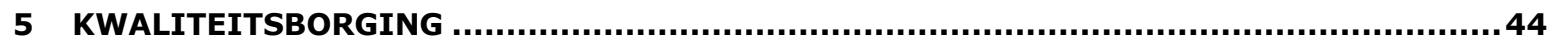

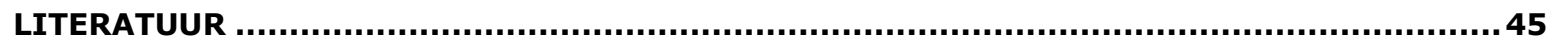




\section{Samenvatting}

De Oosterschelde is belangrijk als broed-, doortrek- en overwinteringsgebied voor watervogels. Steltlopers foerageren bij laagwater op droogvallende slikken en zandplaten. Door de aanleg van de stormvloedkering is er echter sprake van 'zandhonger'; het getij is afgenomen, waardoor het evenwicht tussen erosie en sedimentatie is verstoord. Dit heeft als gevolg dat het intergetijdengebied niet meer voldoende opbouwt, terwijl afbraak tijdens stormen nog wel plaatsvindt. Het areaal aan platen, slikken en schorren neemt hierdoor af en daarmee ook het foerageergebied dat beschikbaar is voor steltlopers.

In deze rapportage zijn in het kader van beleidsondersteunend onderzoek in opdracht van het ministerie van Landbouw, Natuur en Voedselkwaliteit trends van steltlopers en andere benthos-etende vogels in de Oosterschelde geanalyseerd over de periode 1987-2017 om te bepalen hoe de vogelaantallen zich ontwikkelen. Dit is een update van een eerdere rapportage waarin een algehele achteruitgang van vogels over de periode 1987-2010 nog niet was vastgesteld (Troost and Ysebaert 2011). In de huidige studie zijn de volgende steltlopers meegenomen waarvoor naar verwachting de zandhonger tot een vermindering van het foerageergebied kan leiden: bontbekplevier, bonte strandloper, drieteenstrandloper, groenpootruiter, kanoet, kluut, rosse grutto, scholekster, steenloper, strandplevier, tureluur, wulp, zilverplevier. Naast deze steltlopers is ook de bergeend meegenomen omdat die afhankelijk is van hetzelfde foerageergebied.

Voor de analyse zijn maandelijkse vogeltellingen gebruikt van hoogwatervluchtplaatsen in de Oosterschelde. Trendanalyses zijn uitgevoerd voor de hele Oosterschelde en voor deelgebieden West, Centraal, Oost en Noord. Voor de deelgebieden is gebruik gemaakt van zes telmaanden, voor de hele Oosterschelde zijn alle maanden meegenomen. $\mathrm{Er}$ is onderscheid gemaakt in de ontwikkeling op de lange termijn (vanaf telseizoen 1987-2017) en korte termijn (vanaf telseizoen 2010-2011). Ten opzichte van de vorige analyse zijn de aantallen voor de meeste soorten stabiel of afgenomen. De trend van de totale aantallen van alle soorten samen (bovengenoemde selectie) neemt echter nog niet significant af. Op kortere termijn (vanaf het telseizoen 2010-2011) is voor de hele Oosterschelde alleen de bergeend nog significant toegenomen. Vijf soorten (strandplevier, scholekster, zwarte ruiter, kanoetstrandloper en tureluur) zijn significant afgenomen en de rest van de soorten zijn stabiel gebleven of hebben een onzekere trend. Trends zijn verschillend voor de vier deelgebieden in totale aantallen vogels en voor de individuele soorten. Totale aantallen vogels nemen significant af in deelgebied Oost. In deelgebied Noord lijkt ook een lichte daling te zijn ingezet in de laatste twee telseizoenen, maar dit is niet significant. In Centraal en West zijn de aantallen de laatste jaren stabiel.

Als er een verband is tussen de ontwikkelingen in vogelaantallen en de zandhonger, is de verwachting dat de trends zich in de Oosterschelde anders zullen ontwikkelen dan elders. Daarom zijn korte en lange termijn trends vergeleken met trends in de Waddenzee en de hele flywaypopulatie van dezelfde soorten. Het valt op dat trends in de Oosterschelde op lange termijn (periode '87/'88 tot '16/'17) overeen komen met trends in de Waddenzee en flywaypopulatie, maar dat in recente jaren (periode '07/'08 tot '16/'17) duidelijk een slechter beeld te zien is in de Oosterschelde. Zo doen de steenloper en kanoetstrandloper het slechter in de Oosterschelde in vergelijking met zowel de Waddenzee als de flyway. Ook zijn trends voor strandplevier, zwarte ruiter, tureluur en drieteenstrandloper op de korte termijn negatiever in de Oosterschelde vergeleken met de Waddenzee en trends voor groenpootruiter, kluut en bontbekplevier negatiever dan in de flywaypopulatie.

De korte termijn trend van de Oosterschelde vergeleken met andere gebieden suggereert dat de foerageercondities in de Oosterschelde verslechteren. Daarom zou een mogelijk vervolgonderzoek zich kunnen richten op analyse van vogelaantallen in relatie tot het plaatareaal en de aanwezige bodemdieren. Als eerste aanzet hiertoe geven we een kort overzicht van voorspellingen voor het plaatareaal en bodemdieren per deelgebied. Wat betreft plaatareaal vindt de grootste afname de komende decennia waarschijnlijk in deelgebied Oost en Noord plaats. In deelgebied Oost zagen we ook de sterkste afname in vogels. Echter, in deelgebied West werd de grootste afname in oppervlak belangrijk foerageergebied verwacht (platen met een droogval van 40-60\%). Hier zien we nog geen afname in totale aantallen, maar wel voor specifieke soorten. Grofweg is wat betreft de bodemdieren 
recent alleen een afname van dichtheid en biomassa van schelpdieren gemeten in deelgebied Noord. Dit zijn belangrijke prooien voor soorten als scholeksters en kanoetstrandlopers.

Concluderend zien we sinds de vorige rapportages waarbij vogeltrends geanalyseerd werden een afvlakking of zelfs afname van de aantallen voor de meeste soorten. Dit zou kunnen wijzen op een effect van het afnemende plaatareaal. Deze hypothese wordt versterkt doordat de korte termijn vogeltrends negatiever zijn geworden vergeleken met de Waddenzee en flyway populaties voor een aantal soorten. Een gedetailleerdere analyse waarbij recent gemeten platenareaal, droogvalduur en aanwezige bodemdieren meegenomen wordt, zou uitgevoerd moeten worden om meer inzicht te krijgen in de oorzaak van de afnemende vogeltrends. 


\section{$1 \quad$ Inleiding}

\section{$1.1 \quad$ Achtergrond}

\subsubsection{Belang zuidwestelijke Delta en Oosterschelde voor watervogels}

De zuidwestelijke Delta is een belangrijk broed-, doortrek- en overwinteringsgebied voor watervogels. $\mathrm{Na}$ de Waddenzee is het veruit het belangrijkste gebied in Noordwest-Europa (Arts et al. 2019) en vormt een belangrijk knooppunt of schakel in de keten van waterrijke gebieden (wetlands) langs de OostAtlantische trekroute. Deze route wordt gebruikt door trekvogels die broeden in de boreale en arctische gebieden die zich uitstrekken van Canada tot centraal Siberië en die overwinteren in estuaria en waterrijke gebieden langs de Noordwest-Europese en West-Afrikaanse kusten tot in Zuid-Afrika.

De Oosterschelde is binnen de zuidwestelijke Delta één van de belangrijkste gebieden voor watervogels, en het belangrijkste gebied voor steltlopers die bij laagwater foerageren op de droogvallende slikken en zandplaten. Omwille van de internationaal belangrijke vogelaantallen die in de Oosterschelde voorkomen, is het gebied aangewezen onder de Europese Vogel- en Habitatrichtlijn en maakt het onderdeel uit van het Natura 2000-netwerk. Tevens is het gebied een wetland van internationale betekenis onder de Ramsar Conventie. Sinds 1990 is de Oosterschelde aangewezen als beschermd Natuurmonument. Sinds 2002 heeft de Oosterschelde de status van Nationaal Park.

\subsubsection{Zandhonger}

Door de aanleg van de stormvloedkering is er in de Oosterschelde sprake van 'zandhonger'. Het getij is afgenomen, waardoor het evenwicht tussen erosie en sedimentatie is verstoord. Bij rustig weer bouwt het intergetijdengebied zich niet meer voldoende op, terwijl er wel afbraak optreedt tijdens stormen. Hierdoor neemt het oppervlak van platen, slikken en schorren in de Oosterschelde af en wordt tevens de droogvalduur van het intergetijdengebied verkort (van Zanten and Adriaanse 2008; De Ronde et al. 2013). Sinds 1986 is ruim $10 \%$ van het areaal verdwenen. Uitgaande van $60 \mathrm{~cm}$ zeespiegelstijging van 1990 tot 2100 (24 cm over de periode 2010-2060) blijft van de platen en slikken in 2060 ten opzichte van 2010 nog ongeveer 65\% over (zo'n 8000 hectaren) en in 2100 nog ongeveer 40\% (zo'n 4000 6000 hectaren) (de Ronde et al. 2013). Dit zal op termijn negatieve gevolgen hebben voor de natuurlijke kwaliteit, recreatiewaarden en veiligheid van de Oosterschelde (van Zanten and Adriaanse 2008; Zandvoort et al. 2019).

Voor natuur wordt vooral het foerageerhabitat voor steltlopers die op de droogvallende slikken en platen foerageren, bedreigd. Zo blijkt uit berekeningen dat scholeksters mogelijk met tachtig procent zullen zijn afgenomen rond 2045 (van Zanten and Adriaanse 2008). Voor steltlopers en andere vogels zijn doelaantallen gedefinieerd die in het Natura 2000-beheerplan Oosterschelde zijn opgenomen (Ministerie van Infrastrucuur en Milieu and Rijkswaterstaat 2016). Steltlopers waarvoor de zandhonger tot een vermindering van het foerageergebied zal leiden zijn: bontbekplevier Charadrius hiaticula, bonte strandloper Calidris alpina, drieteenstrandloper Calidris alba, groenpootruiter Tringa nebularia, kanoet Calidris canutus, kluut Recurvirostra avosetta, rosse grutto Limosa lapponica, scholekster Haematopus ostralegus, steenloper Arenaria interpres, strandplevier Charadrius alexandrinus, tureluur Tringa totanus, wulp Numenius arquata, zilverplevier Pluvialis squatarola (Tabel 1). Dit geldt tevens voor de bergeend Tadorna tadorna, die afhankelijk is van hetzelfde foerageergebied (Ministerie van Infrastrucuur en Milieu and Rijkswaterstaat 2016). Voor het gemak noemen we de groep aan soorten toch steltlopers, ondanks dat de bergeend niet onder deze groep valt. 
Tabel 1 Vogelsoorten en knelpunten die leiden of kunnen leiden tot een afname in de populaties

\begin{tabular}{|c|c|}
\hline Soort & Knelpunt \\
\hline $\begin{array}{l}\text { Bontbekplevier, bonte strandloper, drieteenstrandloper, } \\
\text { groenpootruiter, kanoet, kluut, rosse grutto, scholekster, } \\
\text { steenloper, tureluur, wulp, zilverplevier }\end{array}$ & $\begin{array}{l}\text { Heden: doelaantallen voor deze steltlopers worden } \\
\text { gehaald } \\
\text { In toekomst: afname foerageergebied door zandhonger }\end{array}$ \\
\hline Strandplevier & $\begin{array}{l}\text { Heden: regionale broedpopulatiedoelen worden niet } \\
\text { gehaald } \\
\text { In toekomst: afname foerageergebied door zandhonger }\end{array}$ \\
\hline Zwarte ruiter & $\begin{array}{l}\text { Heden: doelaantal wordt niet gehaald, oorzaak afname } \\
\text { aantallen onbekend, mogelijk extern } \\
\text { In toekomst: afname foerageergebied door zandhonger }\end{array}$ \\
\hline
\end{tabular}

Bron: Ministerie van Infrastrucuur en Milieu \& Rijkswaterstaat, 2016

In de periode 1987-2010 was er nog geen sprake van een algehele achteruitgang van deze soorten (Troost and Ysebaert 2011; De Ronde et al. 2013). De uitzondering hierop was de scholekster die wel sterk achteruitging. Voor deze soort hebben zowel verlies van plaatareaal door de zandhonger als ook andere factoren, zoals de verplaatsing van mosselteelt van het intergetijdengebied naar dieper gelegen gebieden, (mede) een rol gespeeld (De Ronde et al. 2013). Deze soort neemt echter niet alleen in de Oosterschelde af, maar de hele Nederlandse populatie, waaronder de Waddenzee, en de hele flywaypopulatie staat onder druk door de teruggang van voedselbeschikbaarheid in intergetijdengebieden en in de broedgebieden (van Roomen et al. 2018). Ook de aantallen zwarte ruiters binnen de Oosterschelde gaan achteruit maar het is onduidelijk wat de oorzaak is. Waarschijnlijk is er sprake van een externe factor die hierin sturend is, omdat deze negatieve trend in aantallen zwarte ruiters ook in andere Nederlandse gebieden te zien is. Het ministerie van Landbouw, Natuur en Voedselkwaliteit vindt het van belang dat de trends van deze Natura 2000 steltloper soorten en de bergeend nader worden onderzocht. Daarom heeft Wageningen Marine Research opdracht gekregen om dit binnen Beleidsondersteunend onderzoek 'Natuurambitie Grote Wateren' (BO-43-021.03-001) te onderzoeken.

\subsection{Kennisvraag}

In de studie van Troost \& Ysebaert (2011) zijn de lange termijn ontwikkelingen van $1987 \mathrm{t} / \mathrm{m} 2010$ geanalyseerd. Inmiddels zijn we een kleine 10 jaar verder. In het huidige rapport wordt een update gegeven van Troost \& Ysebaert (2011) waarbij opnieuw gekeken wordt naar de relatie tussen vogelaantallen en plaatareaal: Zien we nu veranderingen in de aantallen die verband houden met de zandhonger en de zeespiegelstijging? Hierbij wordt gekeken naar hoe steltlopers in de Oosterschelde zich ontwikkelen over de tijd en ruimte. Om een idee te krijgen hoe ontwikkelingen in de Oosterschelde zich verhouden tot andere gebieden, zijn trends ook vergeleken met die in de Waddenzee en flywaypopulatie van elke soort.

Deze rapportage focust zich op de vogeltrends in de Oosterschelde en geeft daarmee inzicht in hoeverre zandhonger en zeespiegelstijging de steltloperpopulaties op dit moment mogelijk beïnvloeden. In combinatie met de rapportage over ontwikkelingen in het benthos (Craeymeersch, 2020) en de ontwikkeling in het plaatareaal kan beoordeeld worden in hoeverre aan de Natura 2000instandhoudingsdoelen voor kwaliteit en oppervlak habitat van beschermde steltlopersoorten voldaan kan worden. Daarnaast draagt deze kennis direct bij aan de Systeemrapportage Oosterschelde (https://www.testsysteemrapportage.nl/oosterschelde/). 


\section{Materiaal \& Methode}

\section{$2.1 \quad$ Studiegebied: De Oosterschelde}

De Oosterschelde heeft in de loop der tijd grote veranderingen ondergaan. Oorspronkelijk speelde de Oosterschelde een centrale rol binnen het samenhangende, open estuariene systeem van de zuidwestelijke Delta aan het begin van de vorige eeuw (Schaminée et al. 2019). Ondanks dat de verbinding met de Westerschelde al was verbroken, bestond er nog een open contact tussen de Oosterschelde en alle andere zeearmen en de Noordzee. Tot de uitvoering van de Deltawerken, was er nog sprake van grootschalige natuurlijke dynamiek.

De uitvoering van de deltawerken zijn van grote invloed geweest op de huidige omvang van het Oosterscheldegebied. Na de voltooiing van de Grevelingendam (1964) en de Volkerakdam (1969) vormden Oosterschelde en Krammer-Volkerak aanvankelijk samen één estuarium. Het Volkerakmeer, het Markiezaat en het Zoommeer werden van het getij afgesloten in de periode 1983-1987 (Figuur 1). Door deze ingrepen nam het oppervlak aan intergetijdengebied in het Oosterschelde - KrammerVolkerak gebied met 30\% af. De huidige oppervlakte aan slikken en platen in de Oosterschelde bedraagt circa 11.400 hectare.

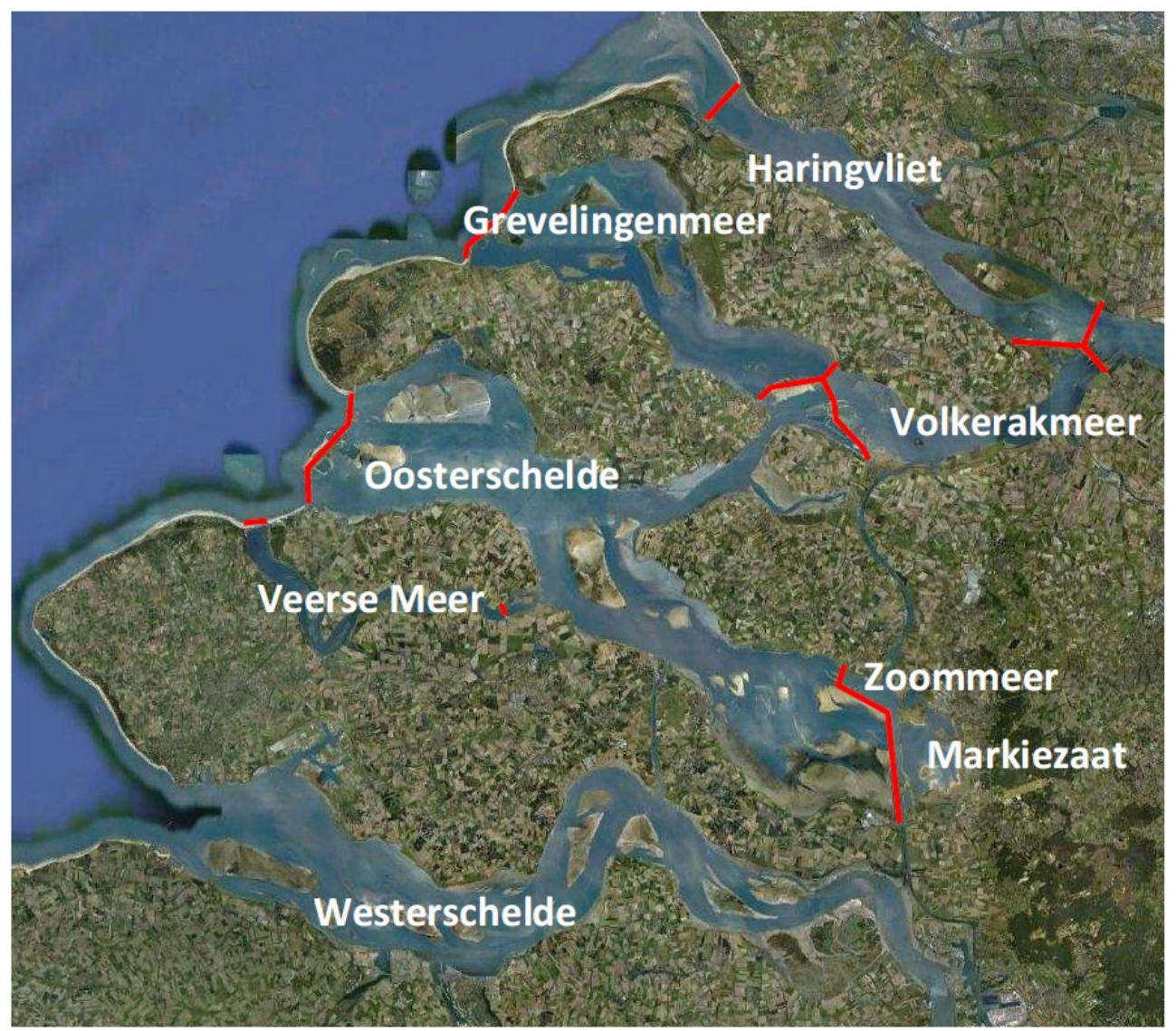

Figuur 1 Kaartje van Oosterschelde en omliggende meren, overgenomen uit Troost en Ysebaert (2011)

De ingrijpende veranderingen in het Oosterscheldegebied als gevolg van de afsluitingen werden gevolgd door meer geleidelijke ontwikkelingen. De belangrijkste hiervan is de zogenoemde zandhonger. Door de bouw van de Oosterscheldewerken is een systeem ontstaan dat morfologisch uit evenwicht is. De aanleg van de stormvloedkering heeft zanduitwisseling met de Noordzee nagenoeg onmogelijk gemaakt. De zandhonger in de geulen leidt tot erosie van de platen en slikken, en de zeespiegelstijging tot een geleidelijke verdrinking. Het areaal platen en slikken loopt geleidelijk terug en op termijn zal het 
droogvallende deel geheel verdwijnen. Tussen 1986 en 2010 is ruim $10 \%$ verdwenen (De Ronde et al. 2013). Uitgaande van $60 \mathrm{~cm}$ zeespiegelstijging van 1990 tot 2100 (24 cm over de periode 2010-2060) blijft van de platen en slikken in 2060 ten opzichte van 2010 nog ongeveer 65\% over (zo'n 8000 hectare) en in 2100 nog ongeveer 40\% (zo'n 4000 - 6000 hectare) (De Ronde et al. 2013).

Om het verlies aan buitendijkse zoute natuurwaarden van de Oosterschelde na de aanleg van de Oosterscheldekering te compenseren, zijn er de laatste decennia een aantal compensatieprojecten gestart. Zeeuwse natuurorganisaties en de Provincie Zeeland hebben begin jaren negentig het Plan Tureluur opgesteld. Dit plan richt zich op het realiseren van een permanente pionierssituatie van een brak milieu, waarbij het waterpeil 's winters $20 \mathrm{~cm}$ hoger staat dan 's zomers. Plaatselijk worden eilandjes gemaaid en vindt begrazingsbeheer plaats en het gebied is hydrologisch geïsoleerd van de omgeving. In totaal is 1.280 ha heringericht, inclusief de zuidkust van Tholen. Op Schouwen wordt het westelijke deel (450 ha) beheerd door Staatsbosbeheer en het oostelijke deel (550 ha) door Natuurmonumenten. De aanleg begon in 1999 en is in 2015 afgerond. Het terrein van Staatsbosbeheer is van groot belang voor steltlopers en kustbroedvogels, het terrein van Natuurmonumenten is door de diversiteit aan landschappen ook van belang voor de noordse woelmuis, ganzen en weidevogels.

Een ander project ter behoud van de schorren en slikken in de Oosterschelde is het terugbrengen van het getij in het Rammegors uitgevoerd door Rijkswaterstaat. In 2013 is door middel van een doorlaatmiddel in de Krabbenkreekdam het contact met de Oosterschelde hersteld en is het zoete Rammegors weer zout geworden. Voorafgaand aan het herstel van de doorlaat zijn alle bomen en struiken van het Rammegors verwijderd en is een brede geul gegraven waardoor het water tijdens vloed het gebied kan binnendringen. $\mathrm{Er}$ is een getij ontstaan met een verschil van ca 1,5 meter. In december 2014 werd de dam geopend, maar al gauw bleek er te veel erosie te zijn bij het doorlaatmiddel. De dam werd weer gesloten totdat er een oplossing voor het probleem was. In februari 2015 ging het doorlaatmiddel weer open, maar moest kort daarna weer gesloten worden omdat er in het Rammegors een stuwdam wegsloeg. De stuwdam moet ervoor zorgen dat met laagwater ook water in het gebied achterblijft. In oktober 2015 is begonnen met herstel van de dam. In december 2016, twee jaar na de eerste opening is de dam uiteindelijk geopend.

Naast de zandhonger in de Oosterschelde spelen andere factoren zoals voedselaanbod, weerscondities, verstoringen en trends van soorten in gebieden buiten de Oosterschelde een rol in de vogelstand. Deze veranderingen worden in meer detail besproken in latere hoofdstukken.

\section{$2.2 \quad$ Vogeltellingen}

Om het verloop van steltlopers in de Oosterschelde te analyseren, zijn telreeksen gebruikt. Vogeldata wordt als gebruikelijk per seizoen gepresenteerd. Een vogel-seizoen loopt van juli tot en met juni het opeenvolgende jaar. Sinds het seizoen 1978/79 worden de watervogels in alle grote zoute wateren in de zoute Delta maandelijks systematisch geteld (Arts et al. 2019). De watervogeltellingen worden vanaf 1990 verricht in het kader van het Biologisch Monitoringprogramma van de Zoute Rijkswateren. Het is een onderdeel van MWTL (Monitoring Waterstaatkundige Toestand des Lands), uitgevoerd in opdracht van de Centrale Informatievoorziening van Rijkswaterstaat.

De tellingen in de Oosterschelde worden uitgevoerd tijdens hoogwater, wanneer vogels zich verzamelen op zogenaamde hoogwatervluchtplaatsen (HVP's). Binnen de Oosterschelde zijn veel kleine teltrajecten gedefinieerd. De meeste daarvan worden al sinds het begin van de tellingen gebruikt (Arts et al. 2019). Boten worden gebruikt om overtijende vogels te tellen op de Neeltje Jansplaat en de Roggenplaat tijdens hoogwater, in combinatie met een simultane telling langs de oevers en inlagen (Arts et al. 2019).

Vanaf maart 2013 is het telprogramma gewijzigd in de zuidwestelijke Delta: in zes maanden (juli, september, oktober, maart, april en juni) van het jaar worden niet alle telgebieden meer geteld, maar alleen een aantal steekproefgebieden. Deze steekproefgebieden maken ongeveer $20 \%$ uit van het totaal aantal telgebieden (Arts et al. 2019). In de andere maanden worden wel alle telgebieden geteld.

De vogeltellingen worden jaarlijks gerapporteerd. De twee rapporten over de tellingen in de jaren 1975/76 - 1983/84 (Meininger et al. 1984; Meininger et al. 1985) kunnen worden beschouwd als een 
beschrijving van de watervogel-populaties in de Delta vóór de voltooiing van de Stormvloedkering en de compartimenteringsdammen (Oesterdam en Philipsdam). Het rapport over 1984/85 - 1986/87 (Meininger and van Haperen 1988) had betrekking op een overgangsfase, waarin o.a. ingrijpend werd gemanipuleerd met het getij in de Oosterschelde. Bovendien werden Oesterdam en Philipsdam gesloten, waardoor eind tachtiger jaren het Zoommeer en Krammer-Volkerak getijloos werden. Daarna verschenen 24 rapporten over tellingen in de nieuwe situatie: de periode 1987/88 - 2016/2017 (Meininger et al. 1994-1998 in serie; Berrevoets et al. 1999-2003, 2005 in serie; Strucker et al. 20062013 in serie; Arts et al. 2014-2018).

\subsection{Geselecteerde soorten}

In dit rapport ligt de focus op Natura 2000-steltlopers die gebruik maken van de droogvallende slikken en zandplaten als foerageergebied. De steltlopers bontbekplevier, bonte strandloper, drieteenstrandloper, goudplevier, groenpootruiter, kanoetstrandloper, kievit, kluut, rosse grutto, scholekster, steenloper, strandplevier, tureluur, wulp, zilverplevier en zwarte ruiter vallen onder het beheerplan Delta-wateren en Oosterschelde 2016-2022 (Ministerie van Infrastrucuur en Milieu and Rijkswaterstaat 2016). De goudplevier Pluvialis apricaria en kievit Vanellus vanellus zijn echter niet meegenomen in de analyses, omdat deze soorten minder afhankelijk zijn van het intergetijdengebied, zij foerageren vooral op graslanden. Naast de steltlopers is ook de bergeend als benthivore vogelsoort meegenomen. In totaal worden dus 15 benthivore soorten meegenomen in de analyse die voor hun voedselvoorziening afhankelijk zijn van intergetijdengebieden.

\section{$2.4 \quad$ Analyse}

\subsubsection{Gebruik tellingen Oosterschelde en deelgebieden}

De boven beschreven teldata is gebruikt voor het in kaart brengen van de vogeltrends in de Oosterschelde. We hebben teldata gebruikt vanaf telseizoen ' $87 /$ ' 88 , toen de afsluiting van het Oosterschelde-estuarium was voltooid, tot en met telseizoen '17/'18. Deze dataset bevat in totaal 31 telseizoenen (sovon. $\mathrm{nl}$ ). Bij het analyseren van tijdreeksen is het belangrijk dat variaties in telinspanning geen effect hebben op de berekende aantalsontwikkeling. Ontbrekende tellingen moeten dus worden bijgeschat, dit is gedaan door 'imputing' (Underhill \& Prys-Jones 1994 in (Strucker et al. 2008)). De bijschattingen zijn uitgevoerd voor de gehele Oosterschelde. Deze data zijn gebruikt om veranderingen over de tijd en binnen het seizoen te beschrijven. Hier is de periode van 1987 tot 1991 als referentie periode gebruikt.

Om meer zicht te krijgen op eventuele veranderingen binnen het gebied, hebben we ook teldata per deelgebied gebruikt. De Oosterschelde is hierbij ingedeeld in West, Noord, Oost en Centraal (Figuur 2). Voor elk deelgebied zijn echter enkel de werkelijk getelde aantallen op HVP's beschikbaar. Daarnaast worden sinds 2013 niet alle telgebieden in elke maand geteld. Voor de analyse per deelgebied is daarom gebruik gemaakt van de zes maanden waarin alle telgebieden zijn geteld: januari, februari, mei, augustus, november, december. Dit zijn maanden waarin doorgaans de grootste aantallen steltlopers voorkomen in de Oosterschelde, want ze vertegenwoordigen de overwinter- en doortrekperiode. Een heel enkele keer is een telgebied door weers- of andere omstandigheden niet geteld (een telgebied is subgebied van de grotere deelgebieden). Echter, deze missende tellingen zijn zo gering dat de seizoensgemiddelden zeker betrouwbaar genoeg zijn om algehele trends te kunnen ontdekken in de data (pers. comm. F. Arts). Ondanks dat deze data niet bijgeschat zijn, en er maar zes maanden beschikbaar zijn, kunnen deze data toch goede inzichten geven in veranderingen en verschuivingen van vogelsoorten. Daarnaast komen de bijgeschatte aantallen en de niet bijgeschatte aantallen over de zes maanden goed overeen (Figuur 3). Voor deze dataset zijn de telseizoenen 1987/1988 tot en met 2018/2019 beschikbaar, in totaal 32 telseizoenen.

Om een beter overzicht te krijgen over de grotere verschuivingen over de tijd, hebben we de data soms ook gepresenteerd in grotere tijdstappen dan een seizoen. Hiervoor hebben we de data opgedeeld in vijf periodes van vier jaar, en één periode van vijf jaar. 


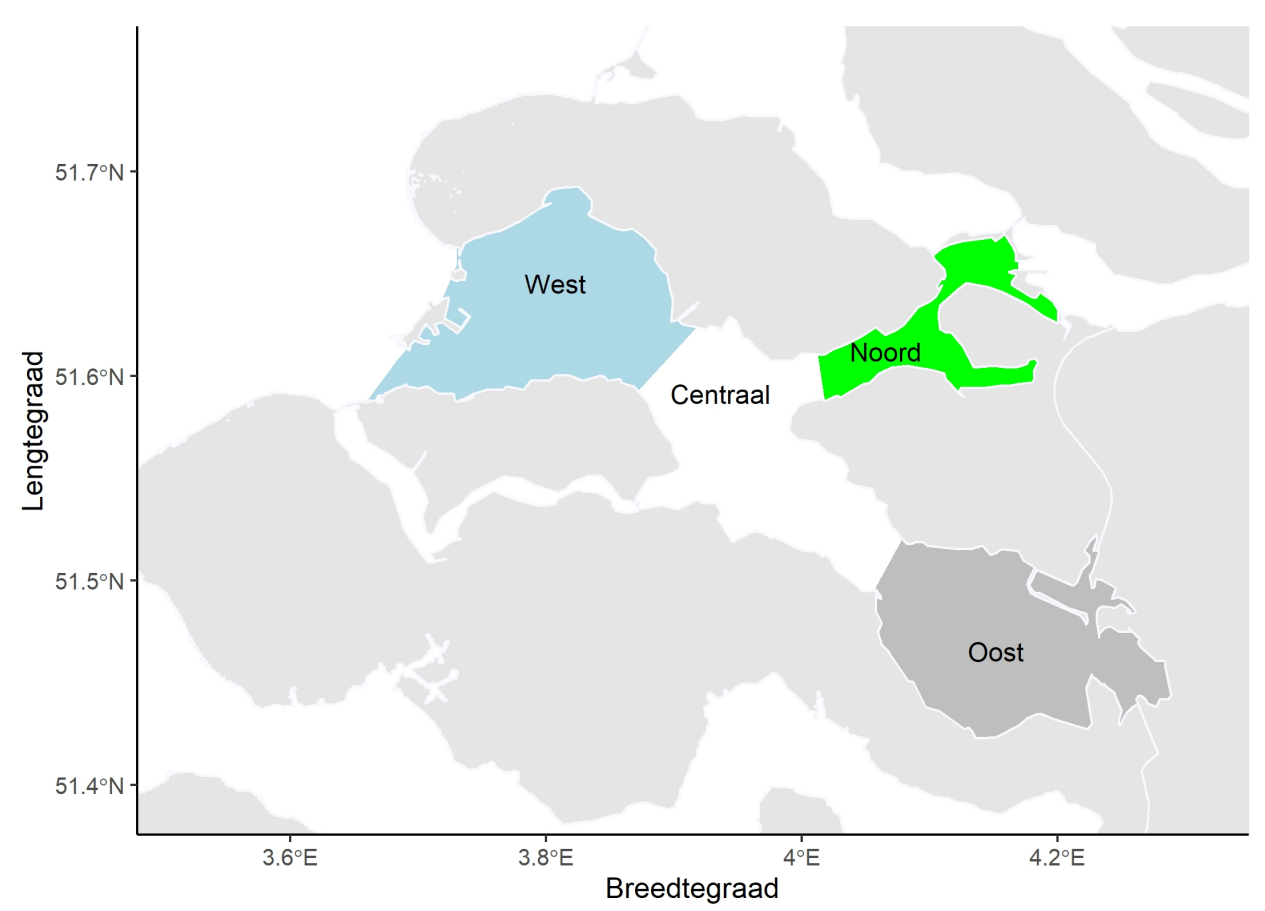

Figur 2 Kaartje van Oosterschelde en de deelgebieden gebruikt in de analyse.

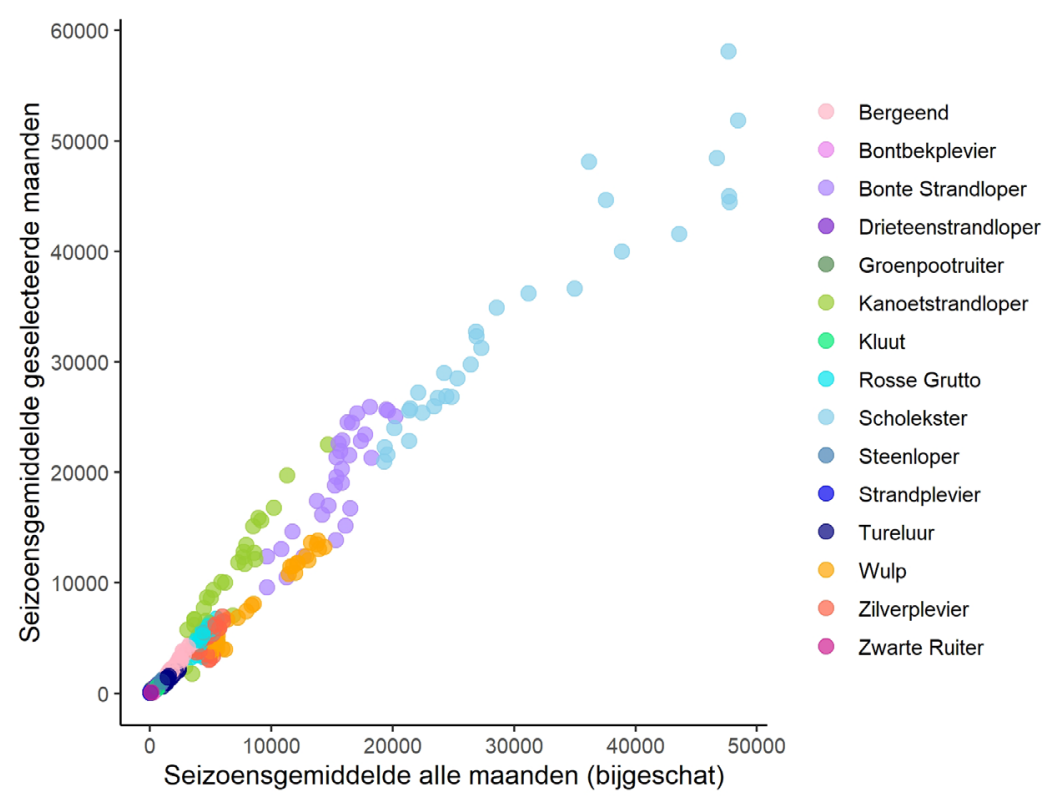

Figur $3 \quad$ Verhouding tussen de bijgeschatte seizoensgemiddeldes ( $x$-as) en de niet bijgeschatte seizoensgemiddeldes van de zes geselecteerde maanden ( $y$-as) per vogelsoort.

\subsubsection{Trendanalyse}

Trendberekeningen worden uitgevoerd op basis van de gemiddelden per seizoen (dat van juli tot juni het opeenvolgende jaar loopt). Dit zijn de bijgeschatte aantallen vogels voor het gehele Oosterschelde en de werkelijk getelde aantallen in de zes geselecteerde maanden voor de deelgebieden. Voor het detecteren van trends in de teldata is het programma TrendSpotter gebruikt. Dit programma is speciaal ontworpen voor het detecteren van flexibele trends zoals die vaak te zien zijn bij vogelaantallen. Trends in vogelaantallen worden vaak gekarakteriseerd door stabiele periodes die worden afgewisseld met plotselinge toe- of afnames. Tevens is dit programma gebruikt om het $95 \%$ betrouwbaarheidsinterval van de vogeltrends te berekenen (Visser 2004; Soldaat et al. 2007). Het 
programma is gerund met behulp van een Rshiny app (ontwikkeld door P. de Vries WMR). De data zijn getransformeerd met een vierdemachtswortel transformatie.

Trendspotter geeft ook een classificatie van de trends in zes verschillende categorieën; een sterke toeof afname, een matige toe- of afname, een stabiele en een niet te bepalen trend. In deze studie laten we zien wanneer vogelaantallen een significante toe- of afname laten zien; een sterke toename ( $>5 \%$ per jaar, ++$)$ in donkergroen, een matige toename $(<5 \%$ per jaar, +$)$ in groen, een matige afname ( $<5 \%$ per jaar, - ) in rood en een sterke afname ( $>5 \%$ per jaar, --) in donkerrood. We maken in deze studie geen onderscheid tussen een niet te bepalen trend en een stabiele trend in de figuren. De trendanalyse is uitgevoerd voor de totalen van de geselecteerde soorten per seizoen over de gehele Oosterschelde en per deelgebied, maar ook per soort.

Met behulp van de data uit de trendanalyse, is de jaarlijkse toe- of afname berekend per soort over de gehele Oosterschelde over een langere periode (seizoen '87-'88 tot '16-'17) en een kortere periode (seizoen '07-'08 tot '16-'17). Deze twee periodes zijn op deze manier gekozen, zodat de toe- en afnames in de Oosterschelde vergeleken konden worden met vogeltrends uit de Waddenzee (Kleefstra et al. 2019) en de hele flywaypopulatie (van Roomen et al. 2018). Op deze manier krijgen we een indicatie of de vogeltrends in de Oosterschelde afwijken van de trends elders. De jaarlijkse toe- of afname (Yearly Change Rate $=$ YCR) is berekend met behulp van Visser et al., 2007. Visser et al (2007) berekenen de verandering over de gehele periode (Total Change Rate $=$ TCR) uit log getransformeerde data. Aangezien wij in deze studie een vierkantswortel-transformatie hebben gebruikt, is de TCR als volgt berekend;

(1) $\mathrm{TCR}=m_{N}^{\wedge} 4 / m_{t}^{\wedge 4}$

Waar $m_{N}$ het "smoothed" populatie aantal berekend door Trendspotter is van een soort in het laatste jaar van de reeks en $m_{t}$ het "smoothed" populatie aantal berekend door Trendspotter is van een soort in jaar $t$. YCR is berekend met formule (2);

(2) $\mathrm{YCR}=e^{\mathrm{Ln}(\mathrm{TCR}) /(\mathrm{N}-\mathrm{t})}$

Waar $\mathrm{N}$ het laatste jaartal is van de reeks (in dit geval 2016) en $t$ het jaartal van het eerste jaartal van een reeks (voor de langere reeks 1987 en voor de kortere reeks 2007).

In de flyway-analyse van van Roomen (2018) is er bij een aantal soorten onderscheid gemaakt tussen ondersoorten en flyway-populaties. Aangezien er in de tellingen van de Oosterschelde geen onderscheid is gemaakt binnen soorten, hebben we voor de toe- en afnames over de flyway gekozen voor de ondersoort of flyway-populatie die voor de Oosterschelde waarschijnlijk bepalend is voor de aantallen, kijkend naar de seizoenspatronen van elke soort. Voor de bontbekplevier hebben we gekozen voor de overwinterende hiaticula ondersoort, alhoewel twee andere ondersoorten ook door het gebied trekken. Voor de rosse grutto, kanoetstrandloper en bonte strandloper zijn de overwinterende subpopulaties bepalend voor de aantallen; de rosse grutto lapponica, de kanoetstrandloper islandica en de bonte strandloper alpina. In de Oosterschelde is voor de steenloper vooral Nearctische flyway populatie aanwezig. Voor de tureluur is er de totanus flyway van GrootBrittannië, Ierland, Nederland \& Frankrijk, die broedt in Nederland, maar ook de Tureluur robusta die overwintert in Noord-West Europa. Gezien de seizoenspatronen zitten beide soorten, in mogelijk vergelijkbare aantallen in de Oosterschelde. Op de lange termijn neemt de robusta ondersoort iets af terwijl de totanus ondersoort stabiel blijft. Op de korte termijn nemen beide ondersoorten af, maar de robusta ondersoort neemt harder af dan de totanus ondersoort. In de analyse hebben we de Oosterschelde trend vergeleken met de robusta flyway populatie, maar de totanus flyway trend is toegevoegd in Bijlage 5, waar ook de trends van andere ondersoorten uit de literatuur staan. 


\subsection{Algemene trends Oosterschelde}

\subsubsection{Absolute aantal vogels over de tijd}

Jaargemiddeld komen in de Oosterschelde $75.860 \pm 13.625$ steltlopers voor ( $\min .60 .576$ in telseizoen 1997 en max. 95.928 in telseizoen 1995). Sinds 2011 fluctueren de aantallen tussen 78 en $87 \%$ t.o.v. de beginperiode (Bijlage 1). In de jaren daarvoor zien we een sterkere jaar-tot-jaarfluctuatie, welke waarschijnlijk onder meer beïnvloed wordt door een aantal strenge winters (Bijlage 2). De maximaal in een maand getelde vogels varieert tussen 95.546 (telseizoen 1997) en 168.669 (telseizoen 1995). Ook in de maximale aantallen zien we de laatste tien telseizoenen minder variatie dan in de periode daarvoor (Bijlage 1). Ten opzichte van de periode net na de afsluiting van de Oosterscheldekering (telseizoenen 1987 - 1991) zijn de aantallen steltlopers in de Oosterschelde in de meeste jaren lager. Over de zes telperiodes zien we een daling van het seizoensgemiddelde in de eerste drie telperiodes, gevolgd door een stijging in de periode 2002-2006, waarna de aantallen weer afnemen. De tijdreeksanalyse laat deze lichte neergaande trend ook zien, maar detecteert geen significante afname over de laatste jaren (Figuur 4).

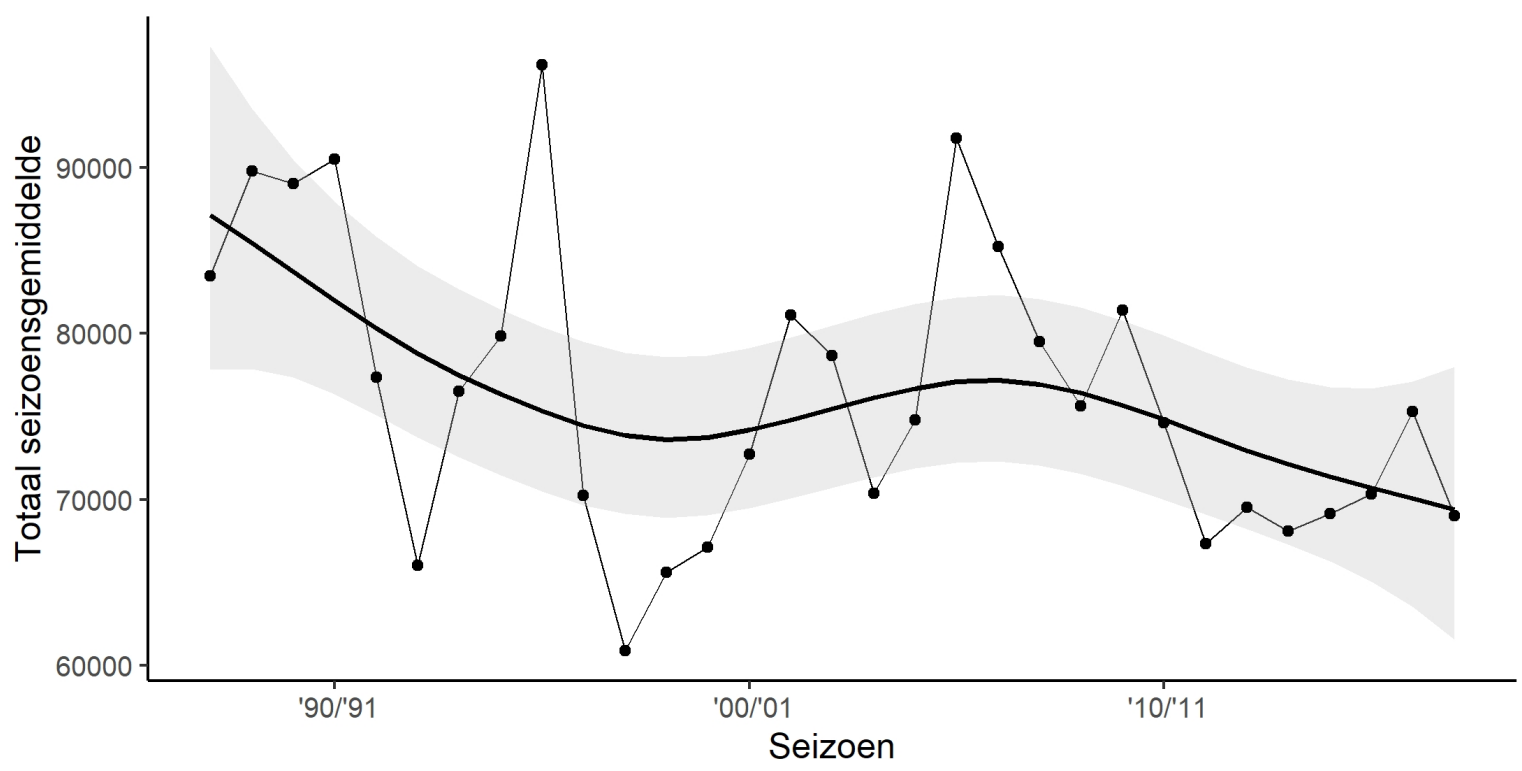

Figuur 4 Tijdreeksanalyse van het gemiddelde van de totale aantallen vogels van de geselecteerde soorten per seizoen in deze studie van telseizoen '87/'89 tot en met '17/'18. De punten representeren de seizoensgemiddelden, deze zijn verbonden door een dunne zwarte lijn. De dikke zwarte lijn is het geschatte populatieverloop door Trendspotter. De grijze band om deze lijn representeert het $95 \%$ betrouwbaarheidsinterval.

\subsubsection{Seizoenspatronen totale aantal vogels over de tijd}

Wanneer we het verloop van de aantallen vogels per periode over het seizoen bekijken, is te zien dat de aantallen steltlopers vooral in de periode tussen augustus en november zijn afgenomen in de Oosterschelde (Figuur 5). In de maanden maart tot en met juli is er geen trendmatig verschil in aantallen vogels in de loop van de tijd. De aantallen bereiken in de laatste telperiode (2012-2017) voor de maanden augustus, september en oktober respectievelijk 73, 62 en 67\% van de aantallen van de eerste telperiode (1987-1991). In de wintermaanden december, januari en februari is dit $88 \%$. 


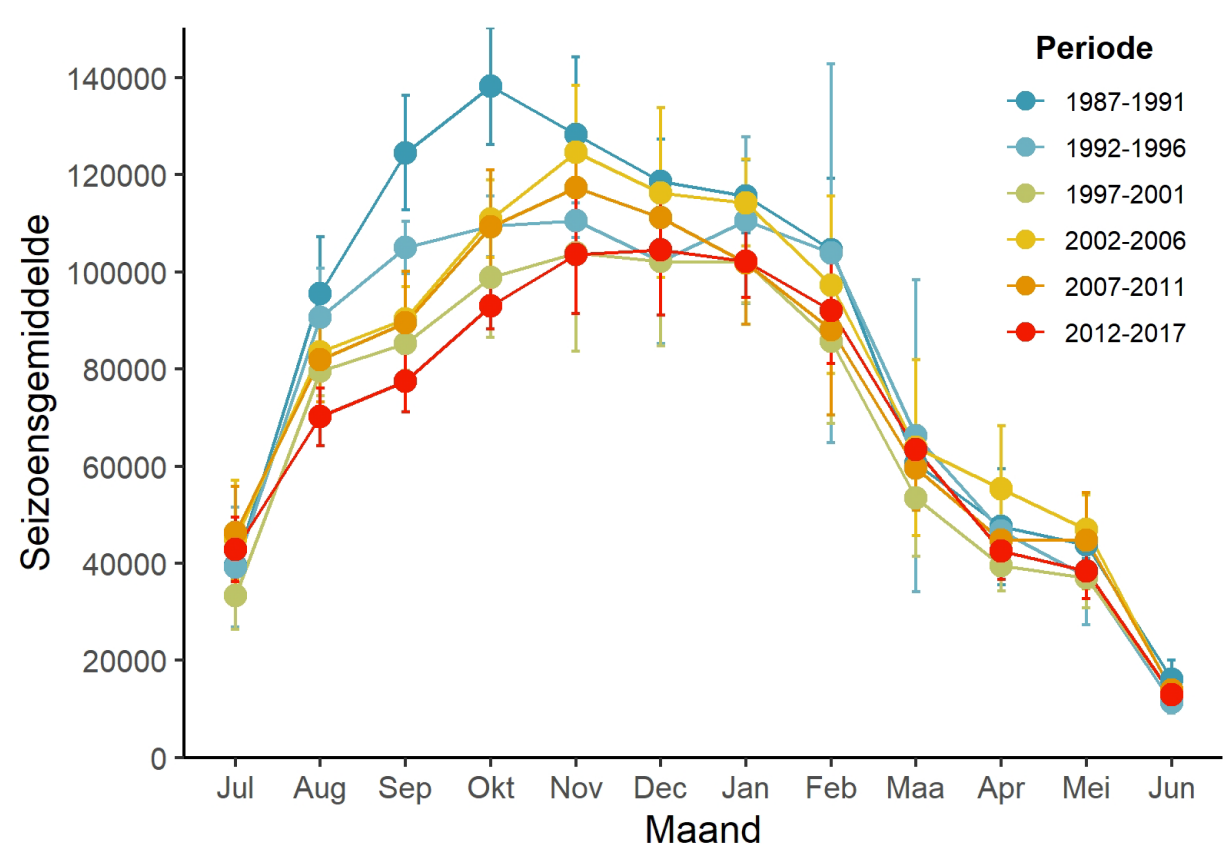

Figur 5 Overzicht van de gemiddelde aantallen en de standaard deviatie van de geselecteerde soorten per telperiode over de maanden van telseizoen '87/'89 tot en met '17/'18.

\subsection{Trends en verspreiding per deelgebied}

Om meer inzicht te krijgen waar toe- en afnames van vogelaantallen binnen de Oosterschelde precies plaatsvinden, hebben we de teldata ook per deelgebied bekeken (zie Figuur 2 voor de verschillende deelgebieden). Sinds de eerste telperiode (1987-1991) zijn er procentueel minder vogels in het westelijke deel van de Oosterschelde en was er een toename in het centrale en noordelijke gedeelte (Figuur 6). Over een iets langere periode is een lichte afname te zien in het oostelijke gedeelte (Figuur 7). De afname in het westelijk deel en toename in het centrale en noordelijke deel aan het begin van de telperiode zijn significant. Verder is er een matige significante afname gaande in het oostelijke deel.
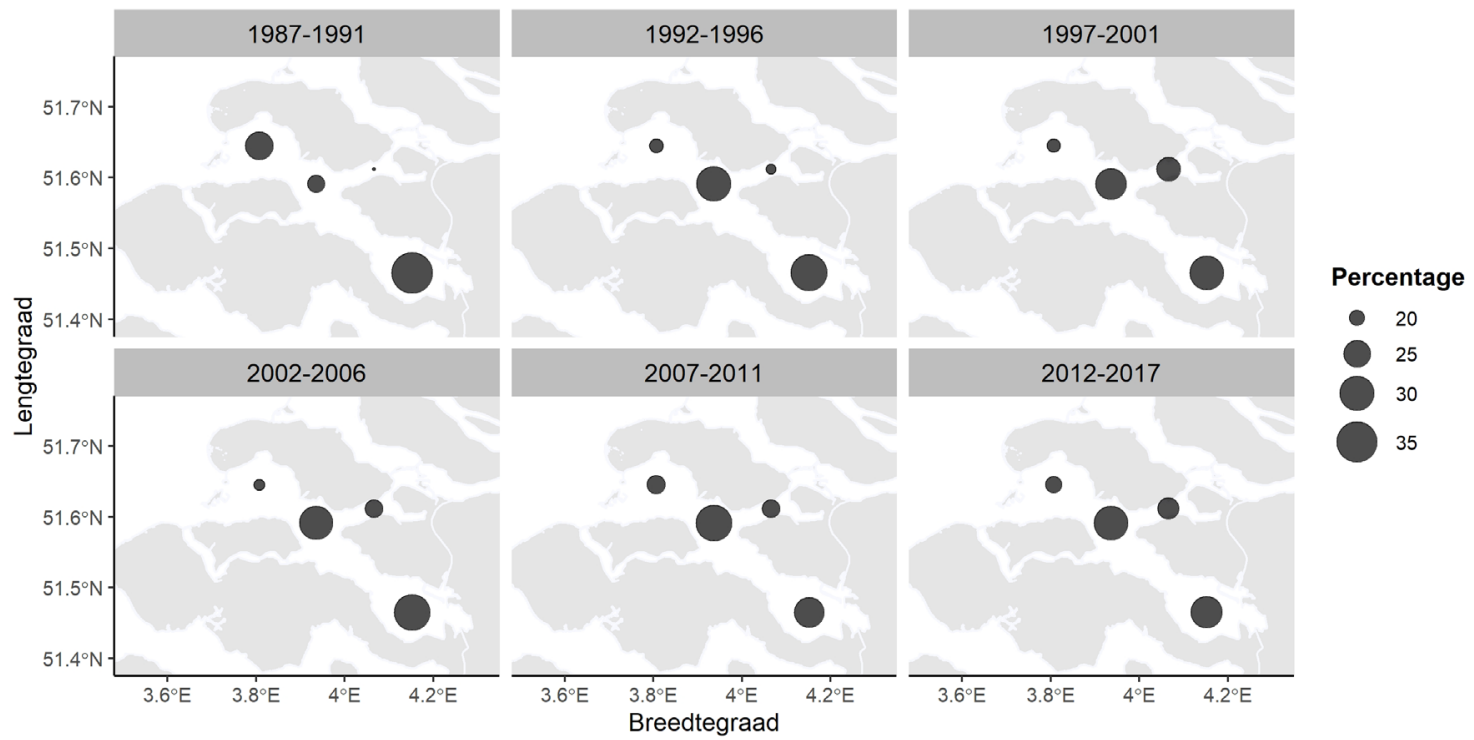

Figuur 6. Overzicht van het procentuele verloop berekend over het gemiddelde aantal vogels per periode over de vier deelgebieden. 


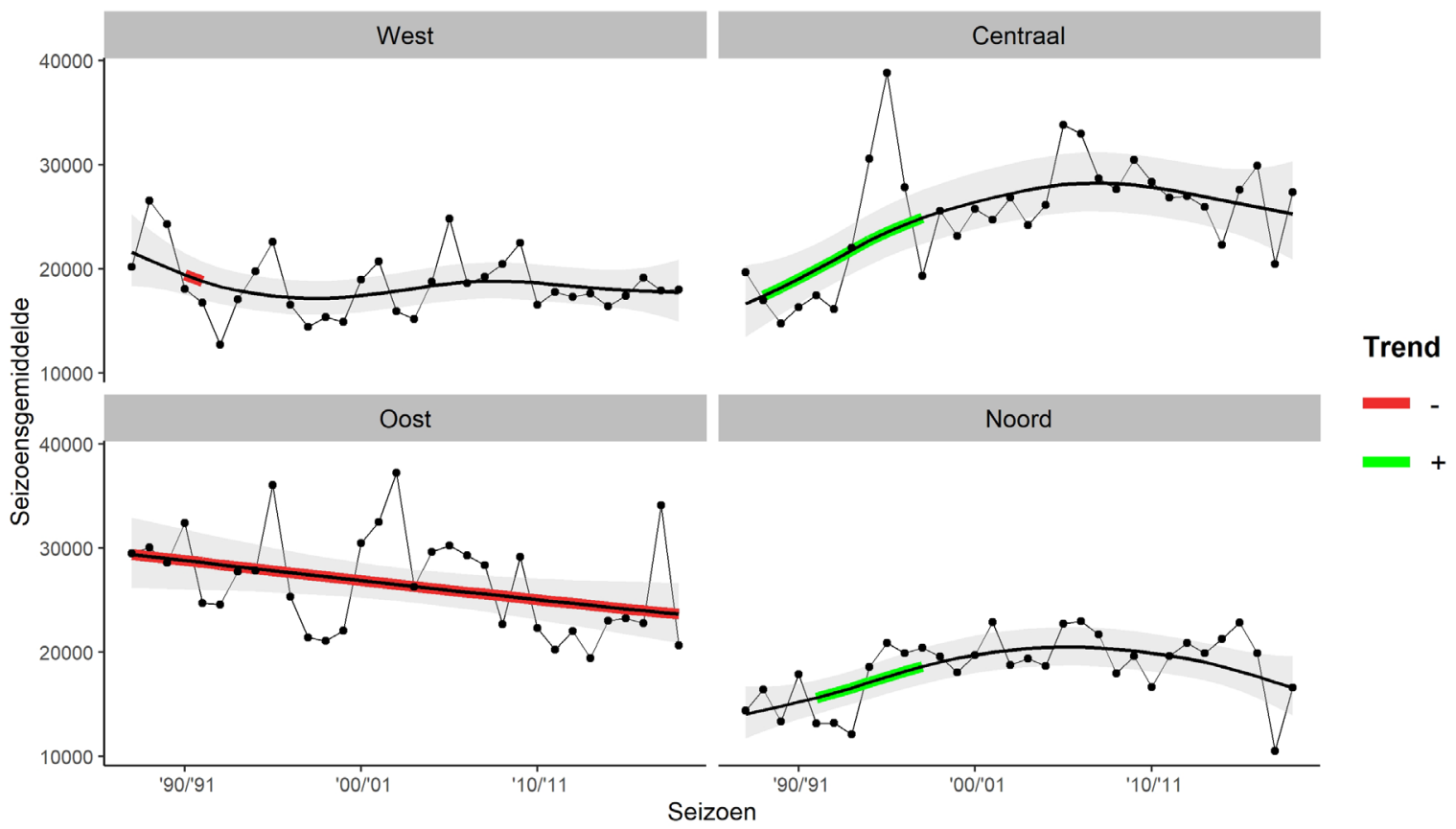

Figur $7 \quad$ Tijdreeksanalyse van de gemiddelde aantallen vogels van de geselecteerde soorten per seizoen per deelgebied van telseizoen '87/'88 tot en met '18/'19. De punten representeren de seizoensgemiddelden berekend over de ruwe data (ongecorrigeerde tellingen van de maanden januari, februari, mei, augustus, november, december). Deze zijn verbonden door een dunne zwarte lijn. De dikkere lijn is het geschatte populatieverloop door Trendspotter. De grijze band om deze lijn representeert het $95 \%$ betrouwbaarheidsinterval. De kleur geeft de trendindicatie aan (zie voor uitleg paragraaf 2.4). 


\subsection{Trends van individuele soorten}

\subsubsection{Oosterschelde}

De meeste soorten zijn in wintermaanden het talrijkst in de Oosterschelde; 100.000 vogels. De talrijkste soorten in de Oosterschelde zijn: bonte strandloper, kanoetstrandloper, rosse grutto, scholekster, wulp en zilverplevier. Zoals ook al te zien was in Figuur 5, is de piek van de meeste steltlopers in de loop van de tijd over het algemeen iets meer opgeschoven van nazomer richting late herfst en winter (Figuur 8). De grote afname in vogels in met name oktober wordt vooral veroorzaakt door de enorme afname in scholeksters in het gebied ( Bijlage 4).

Figuur 9 laat de procentuele verandering zien tussen de referentieperiode (seizoenen 1987/1988 tot 1991/1992) en de laatste vijf telseizoenen (2013/2014 tot 2017/2018). Strandplevier, scholekster en zwarte ruiter zijn fors afgenomen in aantal, terwijl de bergeend, kluut, wulp en drieteenstrandloper het juist veel beter doen. Ter vergelijking is ook de af- en toename zoals die eruit zag in de vorige rapportage (Troost and Ysebaert 2011) gepresenteerd in lichtgrijs. De meeste vogelsoorten laten min of meer hetzelfde patroon zien. Duidelijke uitzonderingen zijn de kanoetstrandloper en de tureluur waarbij de aantallen weer min of meer hetzelfde zijn als in de referentieperiode na een eerdere toename.

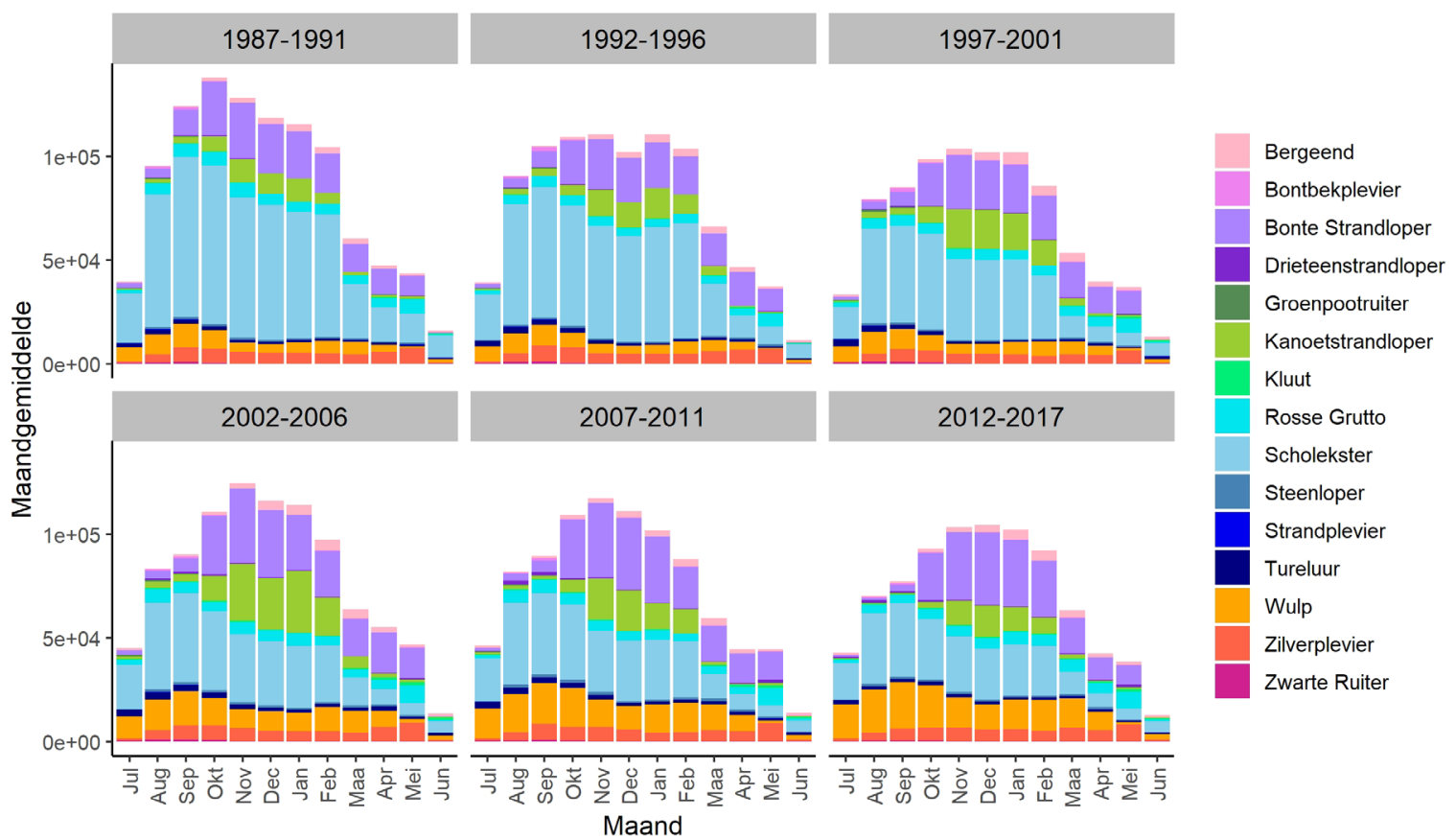

Figur $8 \quad$ Maandgemiddeldes van de geselecteerde soorten in de Oosterschelde over zes telperiodes. 


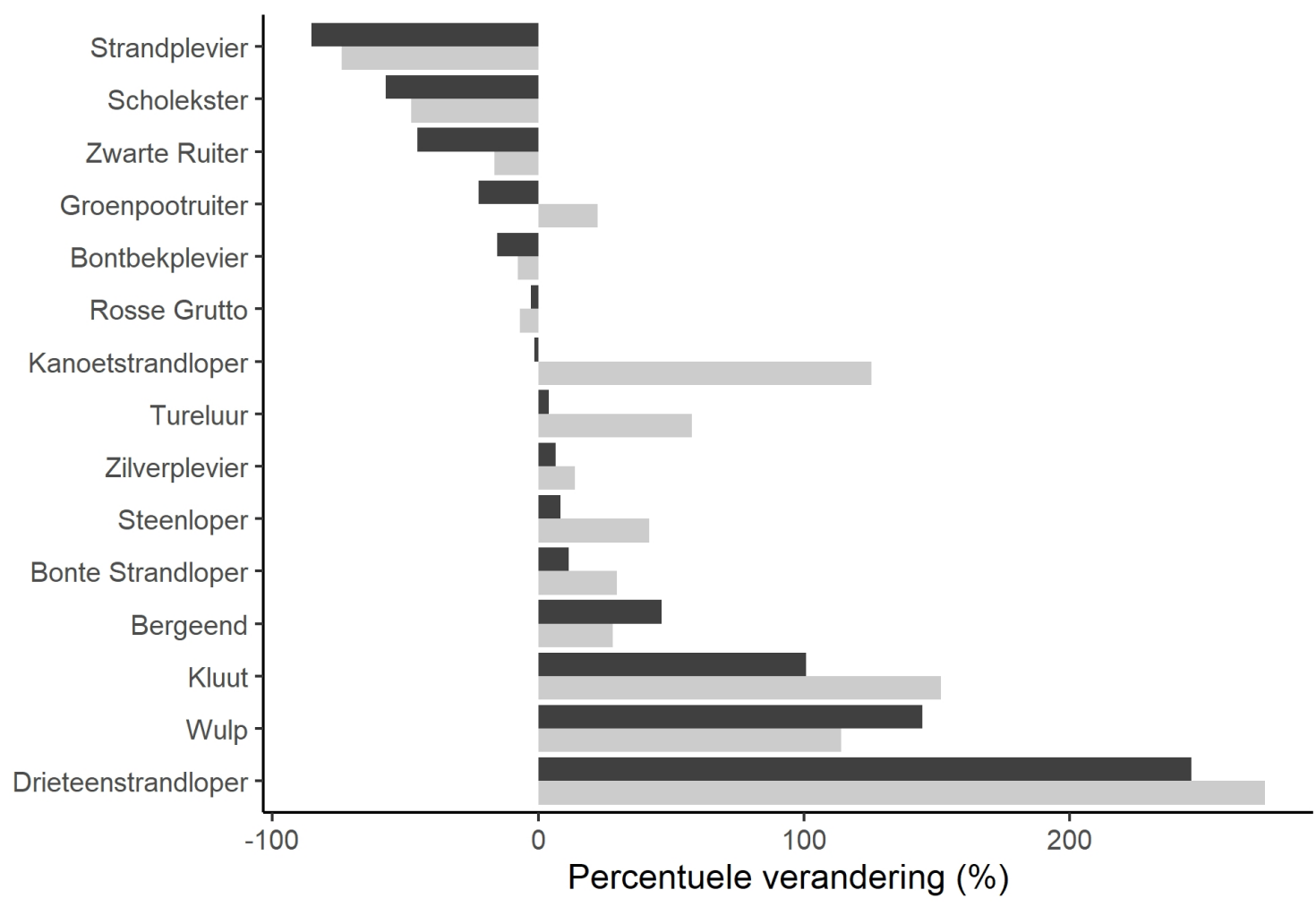

'05/'06-'08/'09 t.o.v. '87/'88-'91/'92

Figuur 9 Overzicht van procentuele toe- of afname van geselecteerde soorten in de seizoenen $2013 / 2014$ tot $2017 / 2018$ ten opzichte van de seizoenen $1987 / 1988$ tot $1991 / 1992$. Ter vergelijking is ook de stand van zaken gepresenteerd in de vorige rapportage (Troost and Ysebaert 2011) in de seizoenen 2005/2006 tot 2008/2009 ten opzichte van de seizoenen 1987/1988 tot 1991/1992 in lichtgrijs. De data is geordend van de soort met de grootste afname tot de soort met de grootste toename berekend over de meest recentste periode.

Over de gehele Oosterschelde is per soort een trendanalyse uitgevoerd. De figuren per soort zijn te zien in Bijlage 4. In Tabel 2 is een samenvattend overzicht van de trendanalyses gepresenteerd. De soorten zijn ingedeeld in significante toe- $\&$ afnames, stabiel of onzekere trend (geen significante toeof afnames over de hele periode). De resultaten van de trendanalyse komen zoals verwacht over het algemeen overeen met de volgorde in Figuur 9; de bovenste soorten in de tabel nemen over het algemeen af, en de onderste soorten toe. De kanoetstrandloper valt enigszins uit de toon in onderstaande tabel; ondanks de toename die te zien is in de grafiek tot $2005 / 2006$ ( Bijlage 4), is deze toename niet significant vanwege de hoge variatie tussen seizoenen. De daaropvolgende steilere afname is wel significant. De laatste kolom van Tabel 2 laat zien of er ook vanaf seizoen 2010-2011 nog een significante toe- of afname is gemeten, om te zien of er sinds de vorige rapportage (Troost and Ysebaert 2011) veranderingen in trends zijn opgetreden. Hier is te zien dat alleen de bergeend nog minimaal één seizoen significant is toegenomen in het laatste decennium. Zeven soorten zijn stabiel of hebben een onzekere trend en zes soorten zijn één of meer seizoenen significant afgenomen.

In Tabel 2 staat ook het hoofdvoedsel van elke soort genoteerd. Dit is informatie uit de literatuur, en voedselkeuze kan zeer verschillen afhankelijk van de aanwezige prooidieren in een gebied. Toch kan het inzicht geven of bepaalde soorten met eenzelfde soort dieet af- of toenemen. De afnemende soorten lijken niet te specialiseren op hetzelfde hoofdvoedsel, met uitzondering van de kanoetstrandloper en scholekster waarvoor schelpdieren de belangrijkste prooi zijn. Andere afnemende soorten hebben ook andere prooidieren als hoofdvoedsel. Er zijn geen duidelijke patronen te zien in toe- of afnames van soorten in verhouding tot hun migratie en broedpatronen (Tabel 2). 
Tabel 2 Overzicht trendanalyse, dieet en seizoensvoorkomen per vogelsoort in de Oosterschelde

Soorten in volgorde van grootste afname naar grootste toename gebaseerd op Figuur 9.

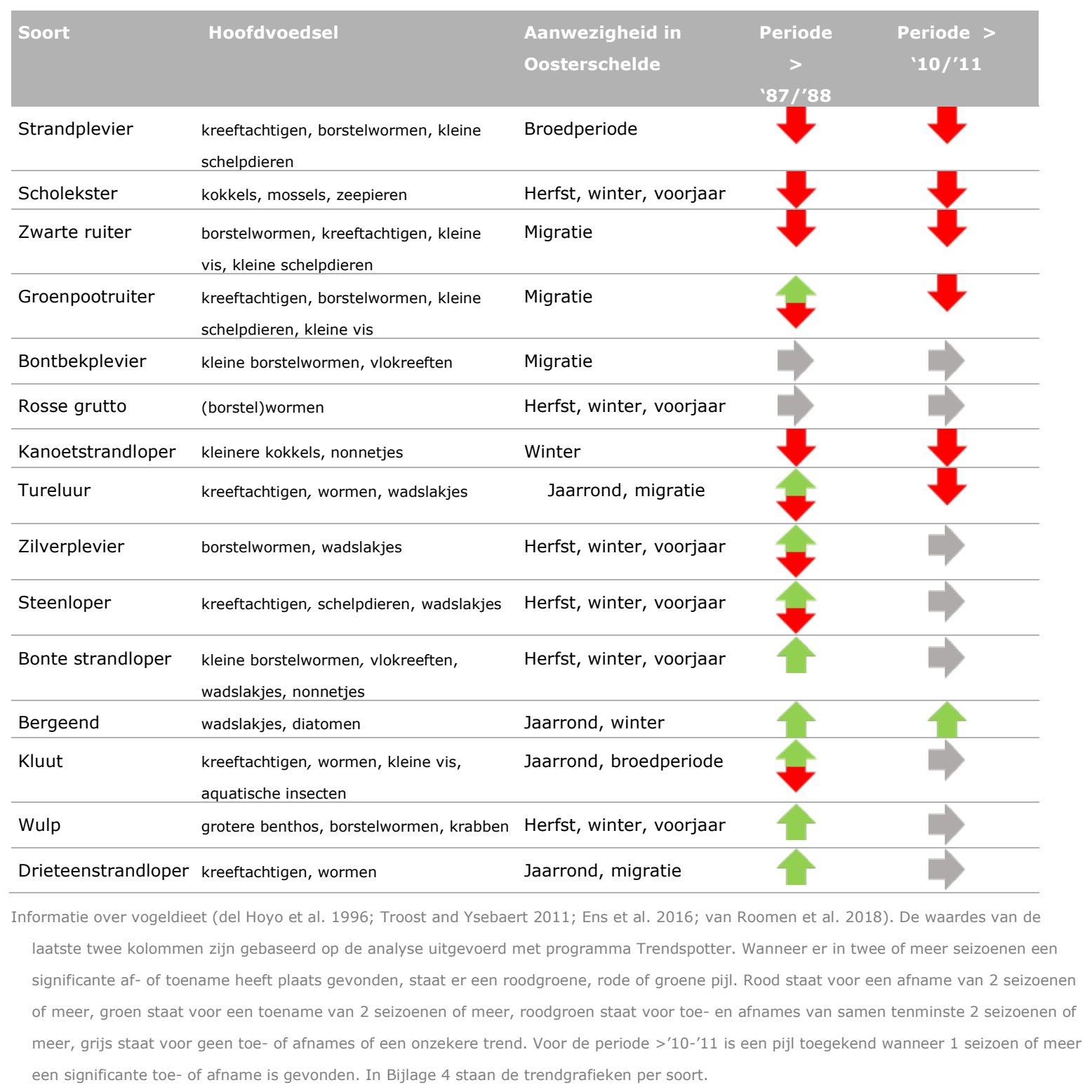

\subsubsection{Per deelgebied}

Om meer grip te krijgen op de reden van toe en afnames per soort, hebben we de vogeltrends ook geanalyseerd per deelgebied. De resultaten zijn samengevat in Tabel 3. Hier is per soort en per deelgebied aangegeven of de soort in de periode vanaf seizoen '87-'88 en in de periode vanaf seizoen '10-'11 significant is toe- of afgenomen, of er zowel toe- en afnames plaatsvonden, of dat de soort stabiel was. Over de gehele periode (Tabel 3, linker kant), zijn er meer soorten die toe- dan afnemen, met name in West, Centraal en Noord. In deelgebied Oost nemen de minste soorten toe en drie soorten af. Dit komt overeen met de eerdere resultaten uit Figuur 7, waar een significante matige afname was te zien in het deelgebied Oost over het totaal aan geselecteerde soorten. Het laatste decennium nemen veel minder soorten nog toe, veel soorten in de deelgebieden lijken gestabiliseerd, met name in deelgebied Noord (Tabel 3, rechter kant). De meeste veranderingen (zowel drie toenemende als drie afnemende soorten) vinden plaats in deelgebied West en Oost. Hieronder wordt de trend per deelgebied en seizoenspatroon per soort besproken in volgorde van grootste afname naar grootste toename ten opzichte van de periode 1987-1991. 
Tabel 3 Overzicht trendanalyse Oosterschelde per soort per deelgebied

Soorten in volgorde van grootste afname naar grootste toename gebaseerd op Figuur 9

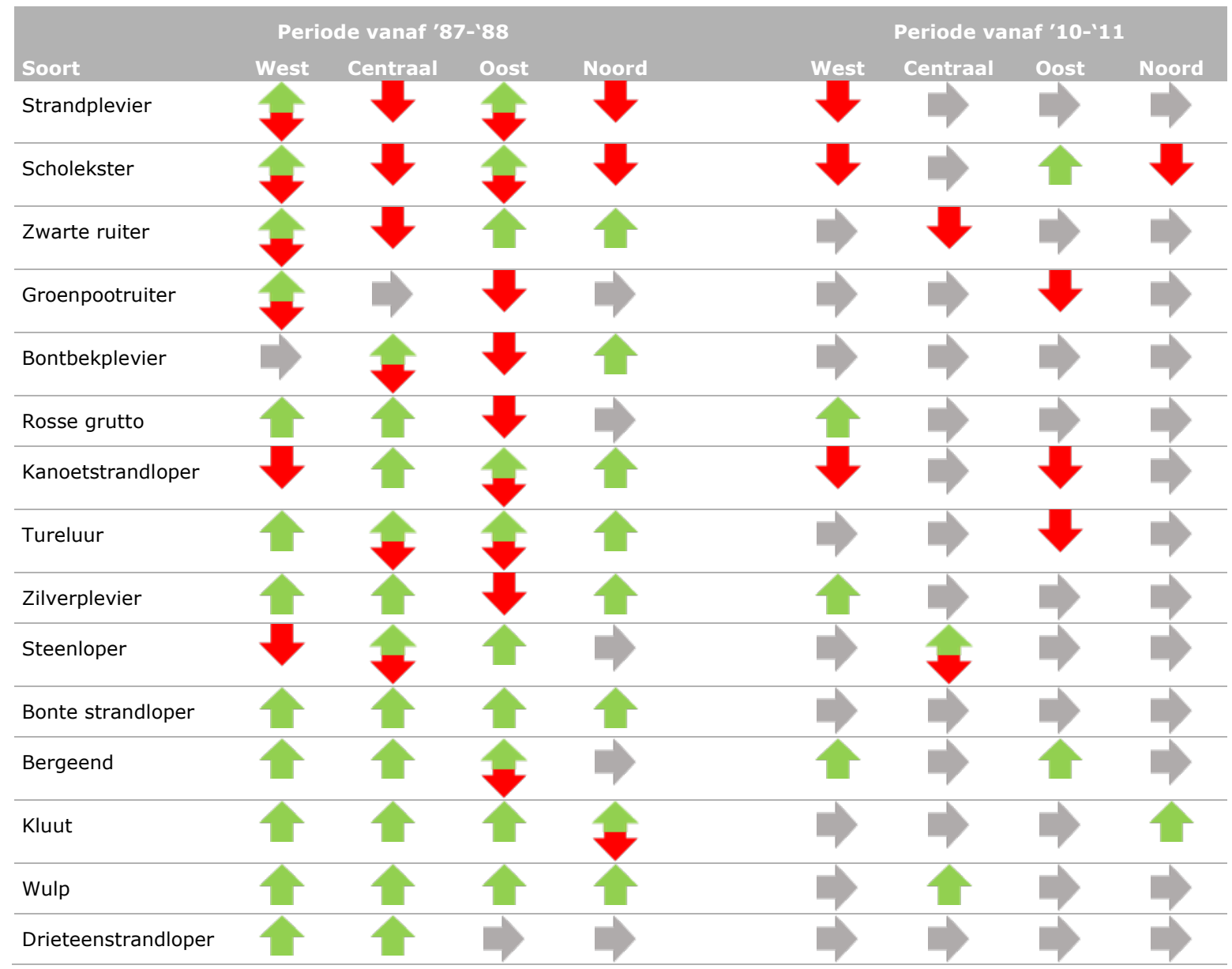

De waardes van de kolommen zijn gebaseerd op de analyse uitgevoerd met programma Trendspotter. Wanneer er in twee of meer seizoenen een significante af- of toename heeft plaats gevonden, staat er een roodgroene, rode of groene pijl. Rood staat voor een afname van 2 seizoenen of meer, groen staat voor een toename van 2 seizoenen of meer, roodgroen staat voor toe- en afnames van samen tenminste 2 seizoenen of meer, grijs staat voor geen toe- of afnames of een onzekere trend. Voor de periode $>^{\prime} 10$-' $^{\prime} 11$ is een pijl toegekend wanneer 1 seizoen of meer een significante toe of afname is gevonden. In Bijlage 4 staan de volledige trend grafieken per soort. 


\subsubsection{Strandplevier Charadrius alexandrines}

De strandplevier is in de lente en zomermaanden in de Oosterschelde te vinden als broedvogel (Figuur 10). Deze soort is in de afgelopen decennia zeer sterk achteruit gegaan, in alle deelgebieden behalve Noord waar de weinige aantallen sterk fluctueren (Figuur 11). De strandplevier is afhankelijk van de droogvallende platen voor voedsel, maar de afnemende aantallen zijn waarschijnlijk bijna geheel te wijten aan een sterk afgenomen broedpopulatie (Meininger and Arts 1997; Strucker et al. 2008). In het oostelijke deelgebied lijken de aantallen weer iets toe te nemen, maar zijn nog steeds erg laag.

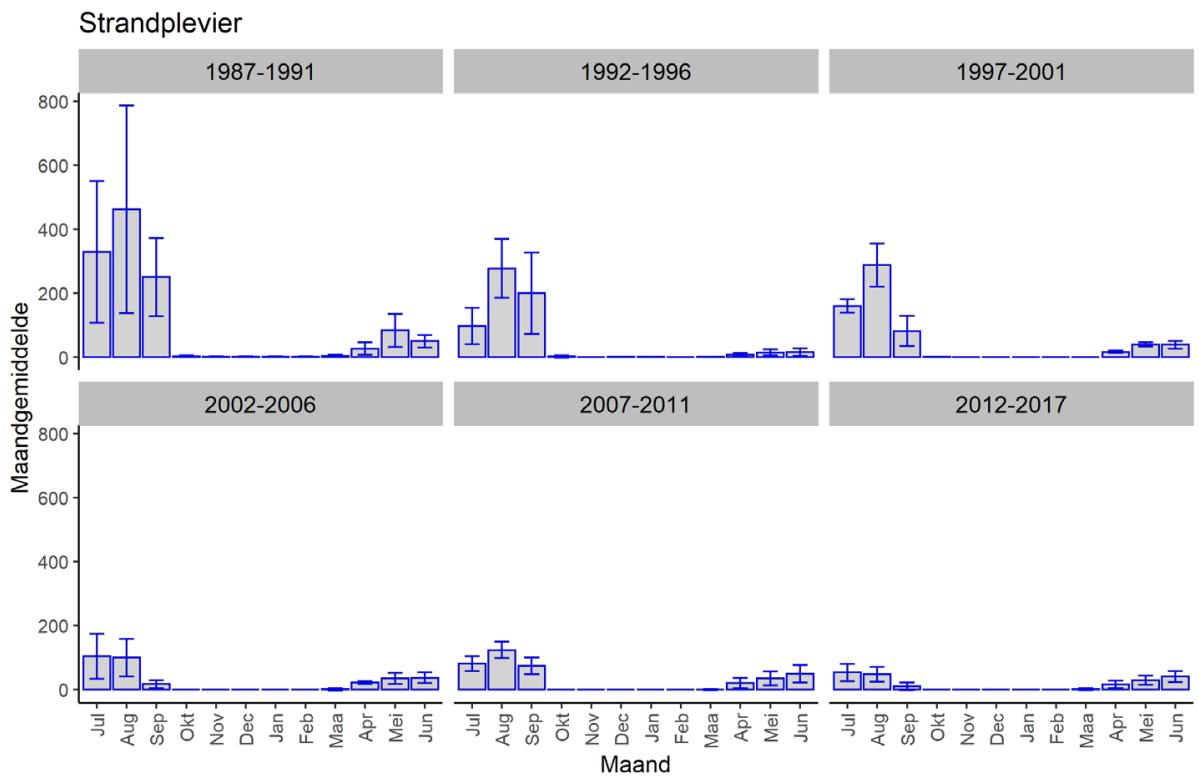

Figuur 10 Seizoenspatroon van de strandplevier per telperiode van vier jaar. De barplots tonen het gemiddelde en de standaarddeviatie per maand.
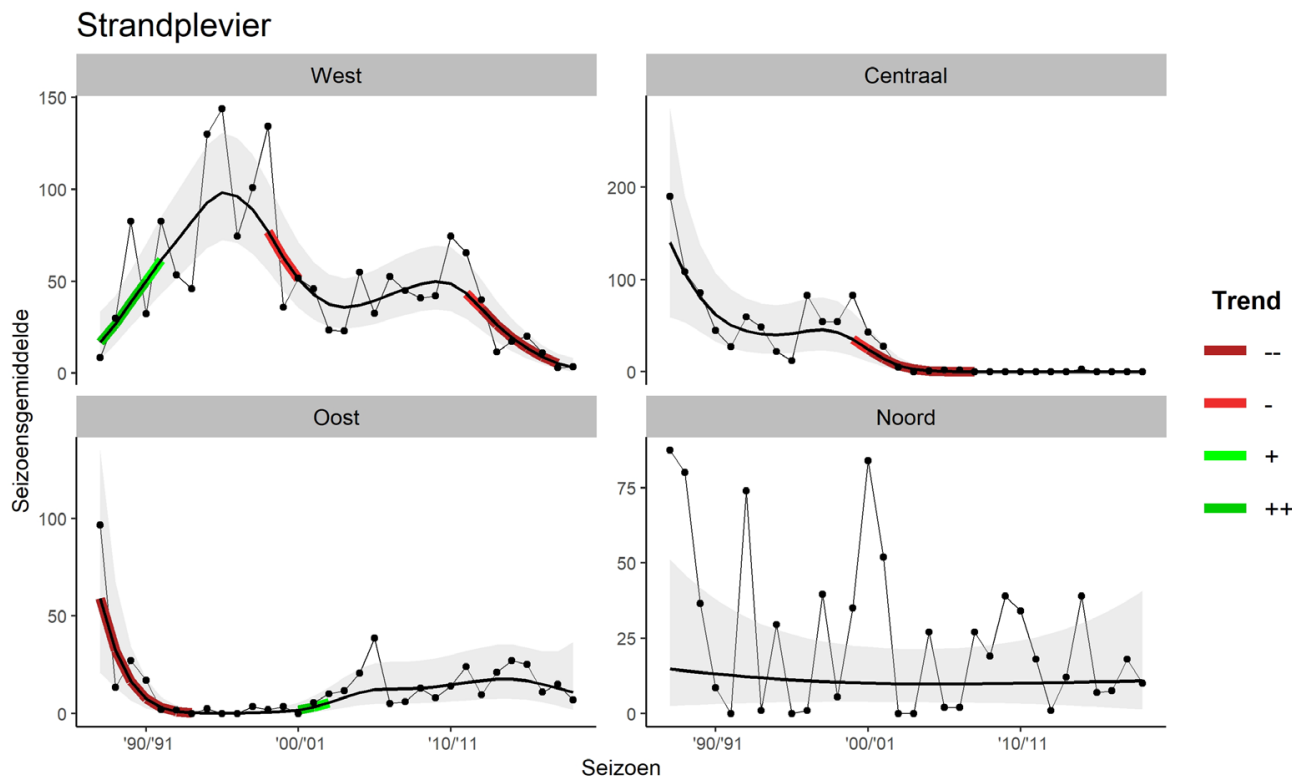

Figuur 11 Trendanalyse van de gemiddelde aantallen strandplevieren per seizoen per deelgebied van telseizoen ' $87 /$ '88 tot en met '18/'19. De punten representeren de seizoensgemiddelden berekend over de ruwe data (ongecorrigeerde tellingen van de maanden januari, februari, mei, augustus, november, december). De dikke lijn is het geschatte populatieverloop door Trendspotter. De grijze band om deze lijn representeert de het $95 \%$ betrouwbaarheidsinterval. De kleur geeft de trendclassificatie aan. Let op het schaalverschil op de $y$-as tussen de figuren. 


\subsubsection{Scholekster Haematopus ostralegus}

De hoogste aantallen scholeksters zijn aanwezig in de Oosterschelde in de nazomer, herfst en winter. De meeste scholeksters verlaten de Oosterschelde in het broedseizoen, maar een klein deel $(\sim 10.000)$ blijft. Dit zijn hoogstwaarschijnlijk vooral sub-adulten en niet-broedende adulten. De aantallen zijn flink afgenomen de laatste decennia, maar het seizoenspatroon is niet veranderd (Figuur 12). De trendanalyse laat zien dat de afname in alle deelgebieden heeft plaatsgevonden. In deelgebieden Centraal en Oost lijkt de afname grotendeels gestabiliseerd, maar aantallen in Noord nemen nog steeds af (Figuur 13). Tegenwoordig zit het hoogste aantal scholeksters in het centrale deelgebied.

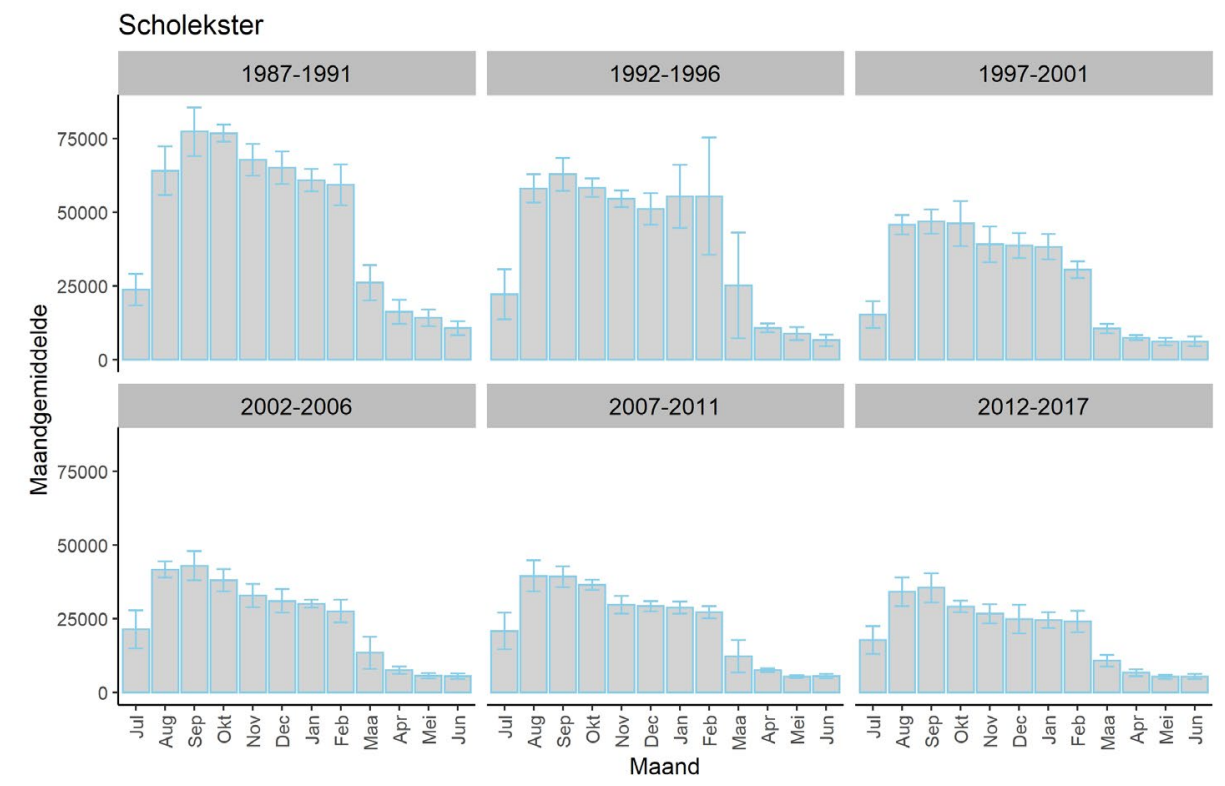

Figuur 12 Seizoenspatroon van de scholekster per telperiode van vier jaar. De barplots tonen het gemiddelde en de standaarddeviatie per maand.

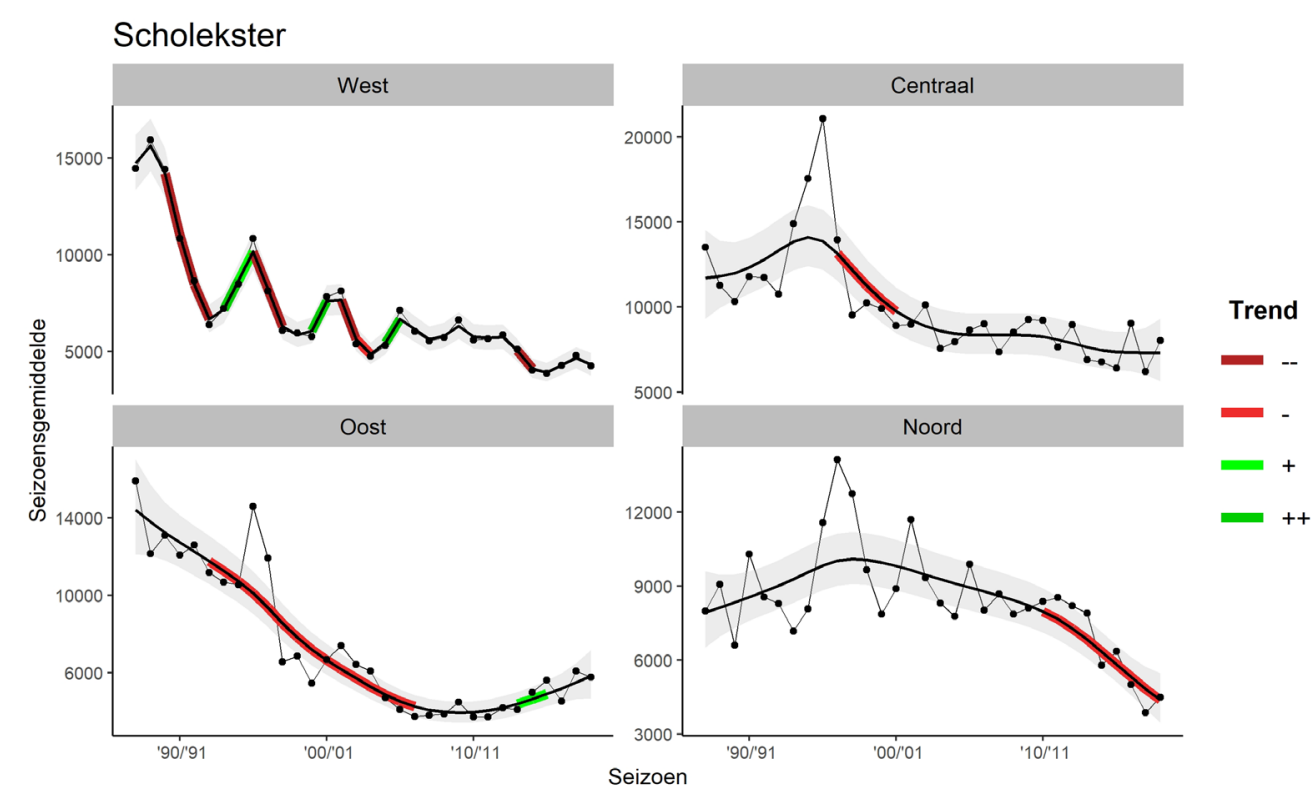

Figuur 13 Trendanalyse van de gemiddelde aantallen scholeksters per seizoen per deelgebied van telseizoen '87/'88 tot en met '18/'19. De punten representeren de seizoensgemiddelden berekend over de ruwe data; ongecorrigeerde tellingen van de maanden januari, februari, mei, augustus, november, december. De dikke lijn is het geschatte populatieverloop door Trendspotter. De grijze band om deze lijn representeert het $95 \%$ betrouwbaarheidsinterval. De kleur geeft de trendclassificatie aan. Let op het schaalverschil op de $y$-as tussen de figuren. 


\subsubsection{Zwarte ruiter Tringa erythropus}

De zwarte ruiter verblijft voornamelijk in de Oosterschelde tijdens de herfstmigratie, wanneer de meeste broedvogels terugkomen uit het noorden van Scandinavië en Rusland. De hoogste aantallen zwarte ruiters zijn in augustus en september geteld (Figuur 14). Een heel klein aantal zwarte ruiters overwintert in Nederland. In alle deelgebieden, behalve West, zijn de aantallen zwarte ruiters afgenomen de laatste jaren. Het oostelijke en noordelijke deelgebied tonen hetzelfde patroon; een sterke toename van zwarte ruiters tussen $\sim 1990-2000$ gevolgd door een niet-significante afname (Figuur 15). In het centrale gedeelte fluctueerden de aantallen sterk, maar nemen nu significant af.

Zwarte Ruiter

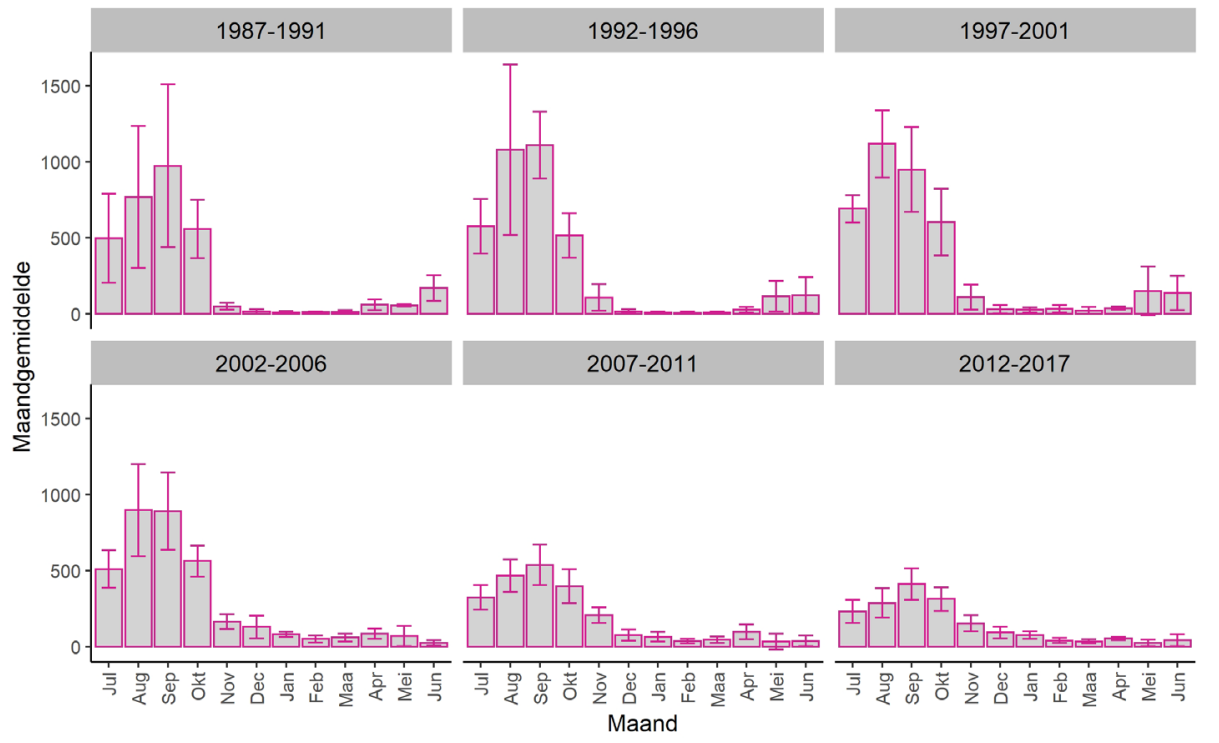

Figuur 14 Seizoenspatroon van de zwarte ruiter per telperiode van vier jaar. De barplots tonen het gemiddelde en de standaarddeviatie per maand.

Zwarte Ruiter
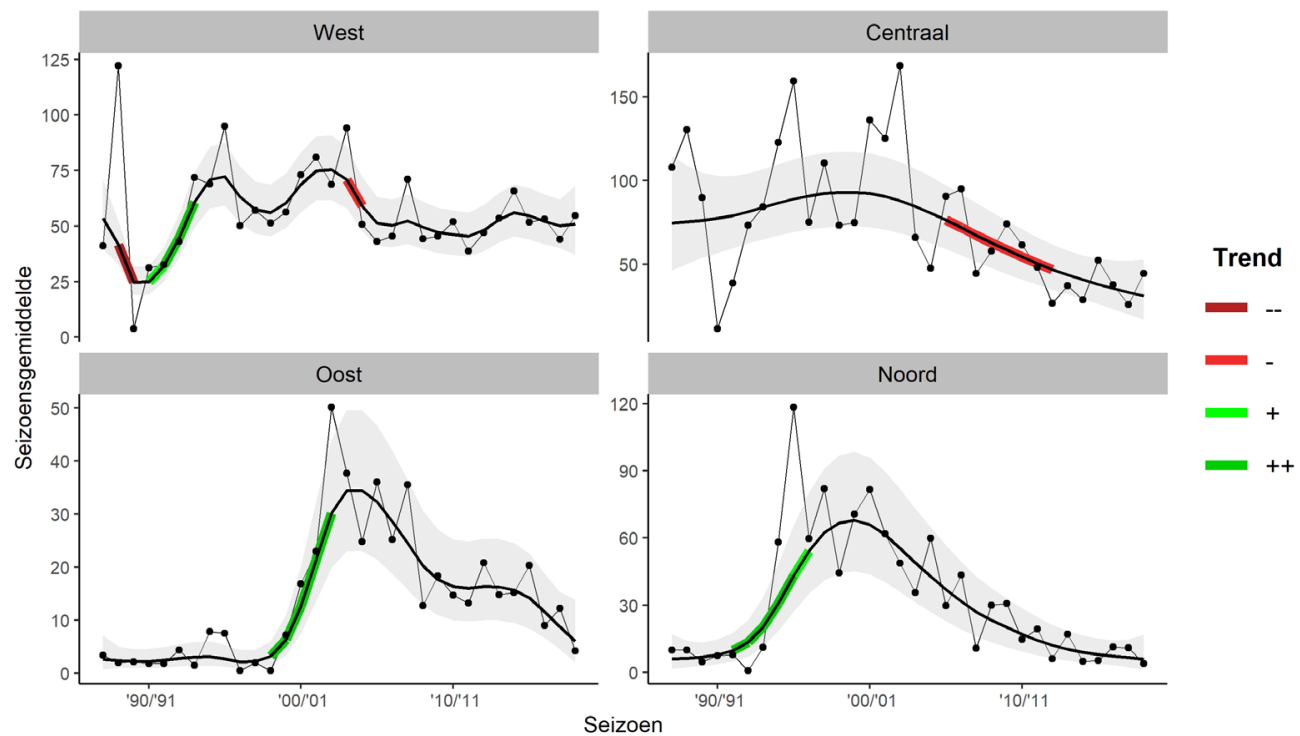

Figuur 15 Trendanalyse van de gemiddelde aantallen zwarte ruiters per seizoen per deelgebied van telseizoen '87/'88 tot en met '18/'19. De punten representeren de seizoensgemiddelden berekend over de ruwe data (ongecorrigeerde tellingen van de maanden januari, februari, mei, augustus, november, december). De dikke lijn is het geschatte populatieverloop door Trendspotter. De grijze band om deze lijn representeert het $95 \%$ betrouwbaarheidsinterval. De kleur geeft de trendclassificatie aan. Let op het schaalverschil op de $y$-as tussen de figuren. 


\subsubsection{Groenpootruiter Tringa nebularia}

De groenpootruiter passeert de Oosterschelde op weg naar de broedgebieden in Noord-Europa en op de weg terug naar overwinteringsgebieden, vooral in Afrika (van Roomen et al. 2018).

Groenpootruiters verblijven in grotere aantallen in de Oosterschelde tijdens de najaarsmigratie (Figuur 16). Tussen 1997 en 2006 zijn aantallen groenpootruiters korte tijd iets toegenomen in deelgebied West. De laatste twee decennia neemt de soort af in zowel West (niet significant) als Oost (significant)( Figuur 17). In het centrale en noordelijke deelgebied blijft de soort min of meer stabiel.

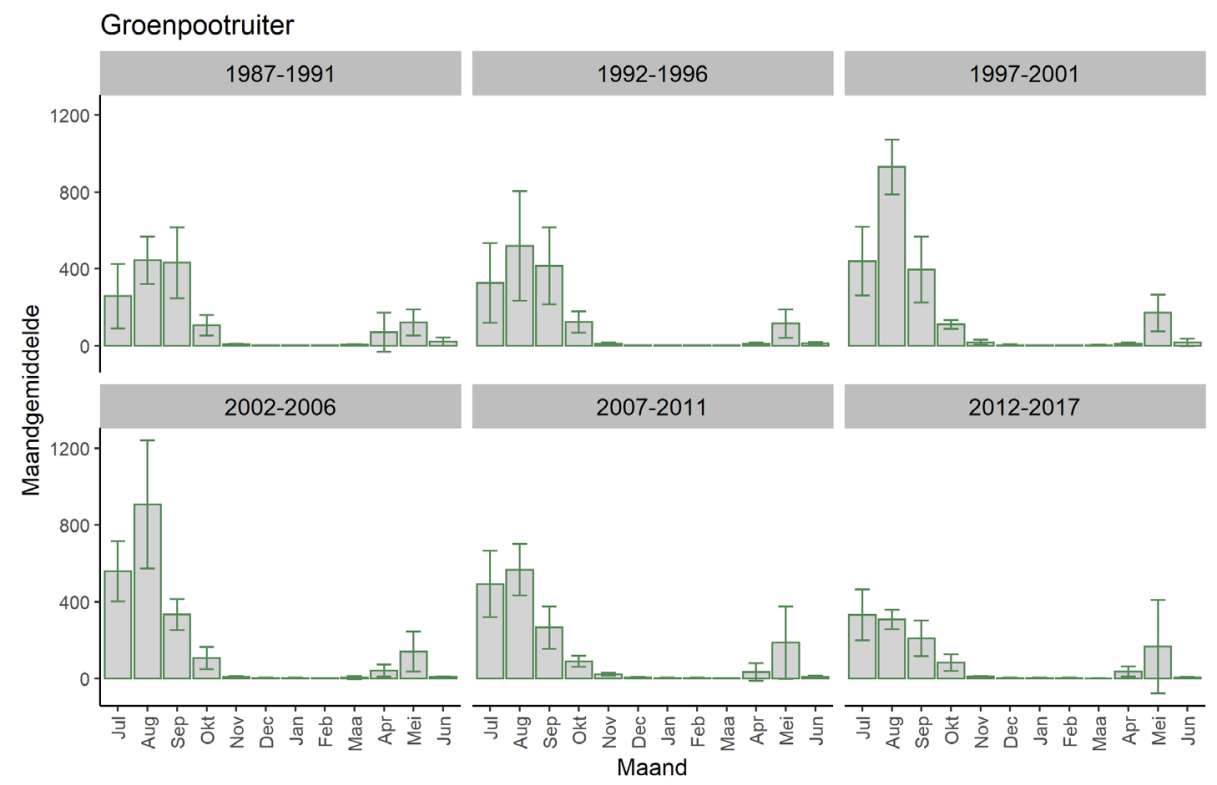

Figuur 16 Seizoenspatroon van de groenpootruiter per telperiode van vier jaar. De barplots tonen het gemiddelde en de standaarddeviatie per maand.

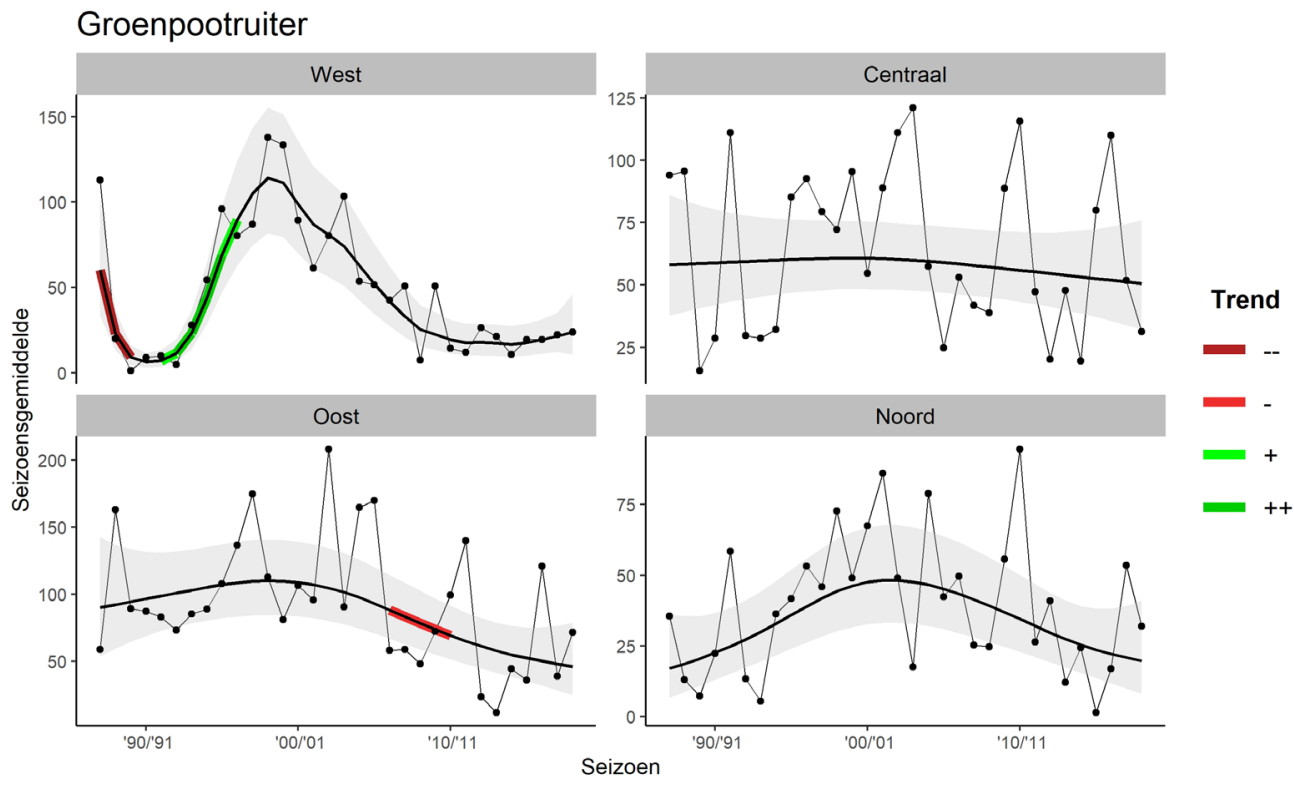

Figuur 17 Trendanalyse van de gemiddelde aantallen groenpootruiters per seizoen per deelgebied van telseizoen '87/'88 tot en met '18/'19. De punten representeren de seizoensgemiddelden berekend over de ruwe data (ongecorrigeerde tellingen van de maanden januari, februari, mei, augustus, november, december). De dikke lijn is het geschatte populatieverloop door Trendspotter. De grijze band om deze lijn representeert het $95 \%$ betrouwbaarheidsinterval. De kleur geeft de trendclassificatie aan. Let op het schaalverschil op de $y$-as tussen de figuren. 


\subsubsection{Bontbekplevier Charadrius hiaticula}

De bontbekplevier is vooral in de Oosterschelde tijdens de migratietijd, met een piek in het najaar (Figuur 18). Er komen drie ondersoorten voor in Europa; de C. h. hiaticula die onder andere broedt in Nederland en omringende landen en ook overwintert in Europa (van Roomen et al. 2018). Het is deze ondersoort die in de winter in de Oosterschelde is te vinden (Strucker et al. 2010). De twee andere ondersoorten trekken door Nederland op weg naar broed- en overwinteringsgebieden in mei en vervolgens weer in de herfst waar ze de Oosterschelde aan kunnen doen. $C$. $h$. tundrae broedt in Noord-Europa en Rusland en overwintert in Afrika en C. h. psammodroma broedt in Canada, Groenland en IJsland en overwintert in West en Zuid Afrika. De najaarspiek is vooral de laatste vijf jaar flink lager. De afname is vooral te zien in het oostelijk deelgebied (Figuur 19). In de andere deelgebieden zijn de aantallen relatief stabiel. Centraal en West zijn de belangrijkste gebieden in termen van aantallen.

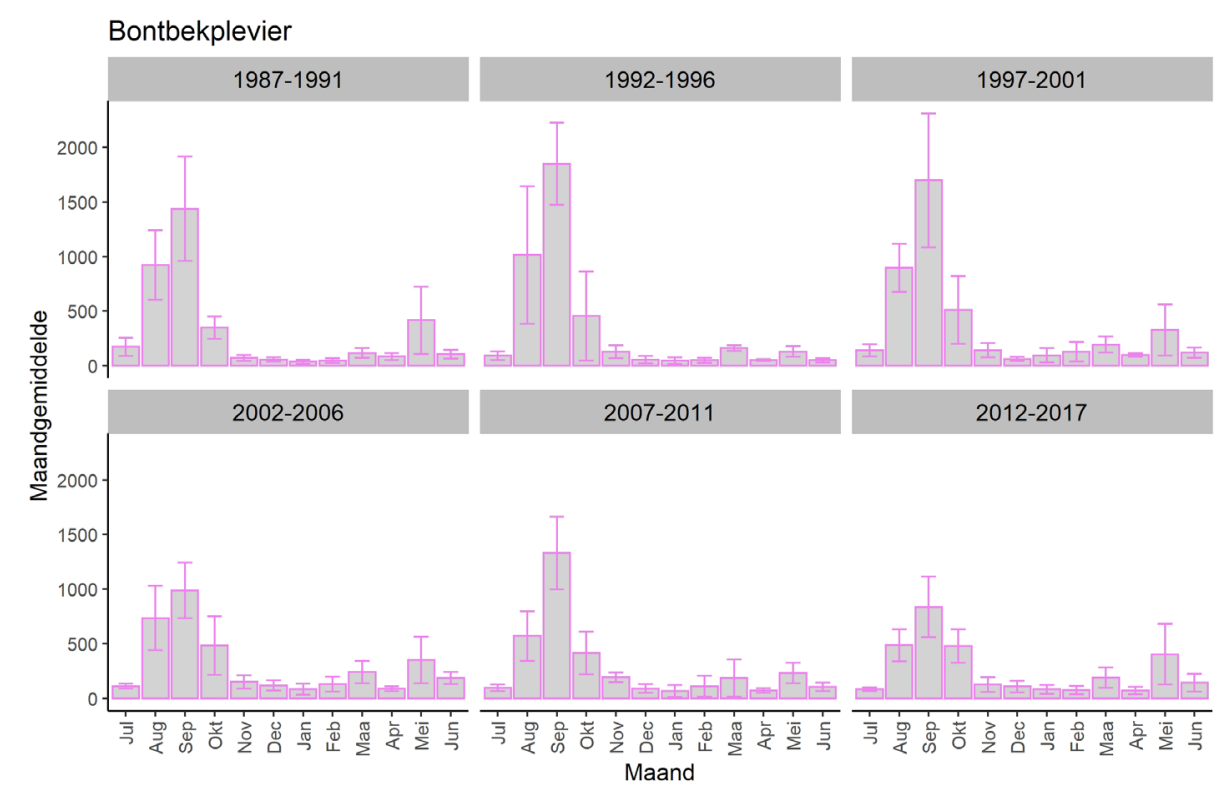

Figuur 18 Seizoenspatroon van de bontbekplevier per telperiode van vier jaar. De barplots tonen het gemiddelde en de standaarddeviatie per maand.

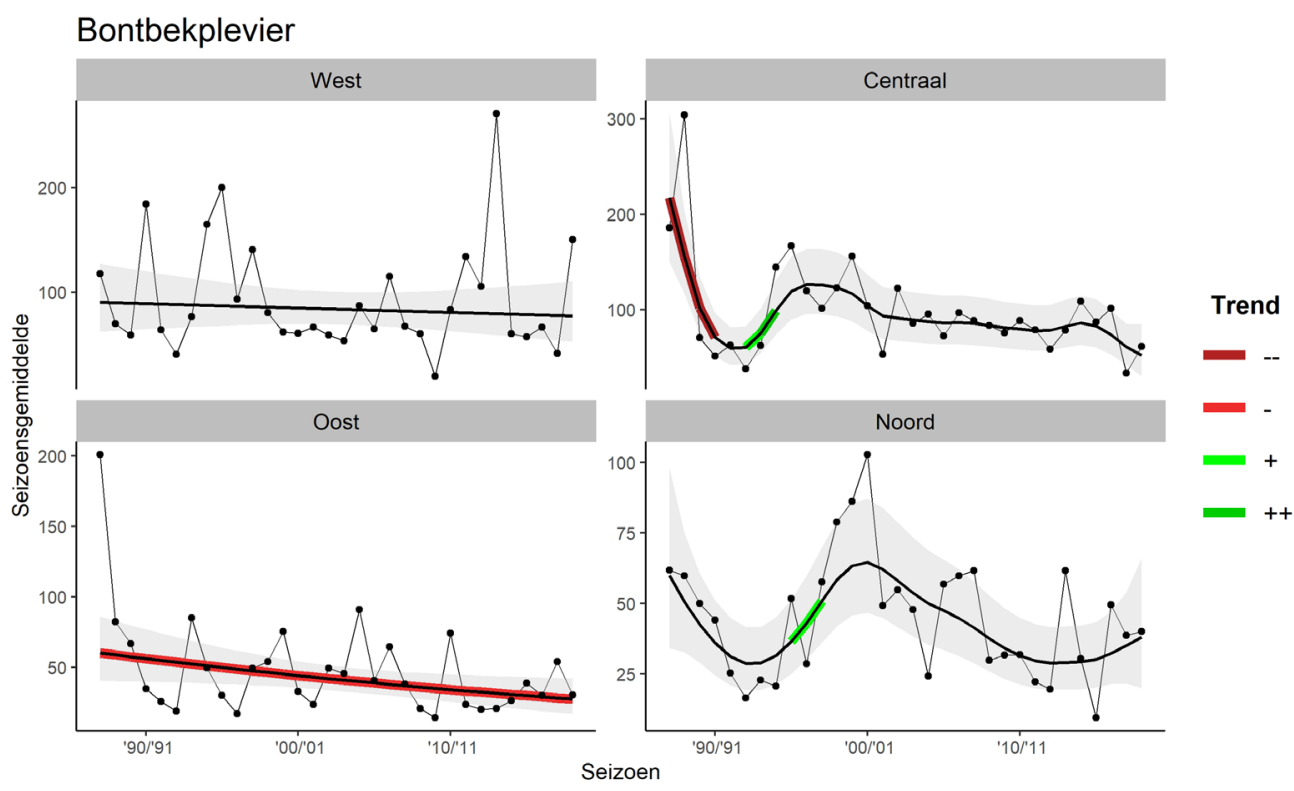

Figuur 19 Trendanalyse van de gemiddelde aantallen bontbekplevieren per seizoen per deelgebied van telseizoen '87/'88 tot en met '18/'19. De punten representeren de seizoensgemiddelden berekend over de ruwe data (ongecorrigeerde tellingen van de maanden januari, februari, mei, augustus, november, december). De dikke lijn is het geschatte populatieverloop door Trendspotter. De grijze band om deze lijn representeert het $95 \%$ betrouwbaarheidsinterval. De kleur geeft de trendclassificatie aan. Let op het schaalverschil op de $y$-as tussen de figuren. 


\subsubsection{Rosse grutto Limosa lapponica}

Rosse grutto's zijn bijna jaarrond aanwezig in de Oosterschelde, met uitzondering van de broedtijd in juni en juli (Figuur 20). Er komen twee ondersoorten van de rosse grutto in de Oosterschelde. De $L$. I. lapponica broedt in Scandinavië en overwintert in Waddenzee en Deltagebied. Deze ondersoort wordt dus vooral gezien in de Oosterschelde. De ondersoort L. I. taymyrensis trekt door Nederland op weg naar broed- of wintergebied in West-Afrika (Rappoldt et al. 2003). De piek in mei en de iets hogere aantallen in vooral augustus worden hoogstwaarschijnlijk verklaard door migratie van deze ondersoort. De rosse grutto is in totale aantallen stabiel gebleven. In deelgebied West is de soort over de hele periode significant toegenomen (Figuur 21). Dit is ook het gebied met gemiddeld de meeste vogels. In de anderen gebieden zijn recentelijk geen grote veranderingen opgetreden.

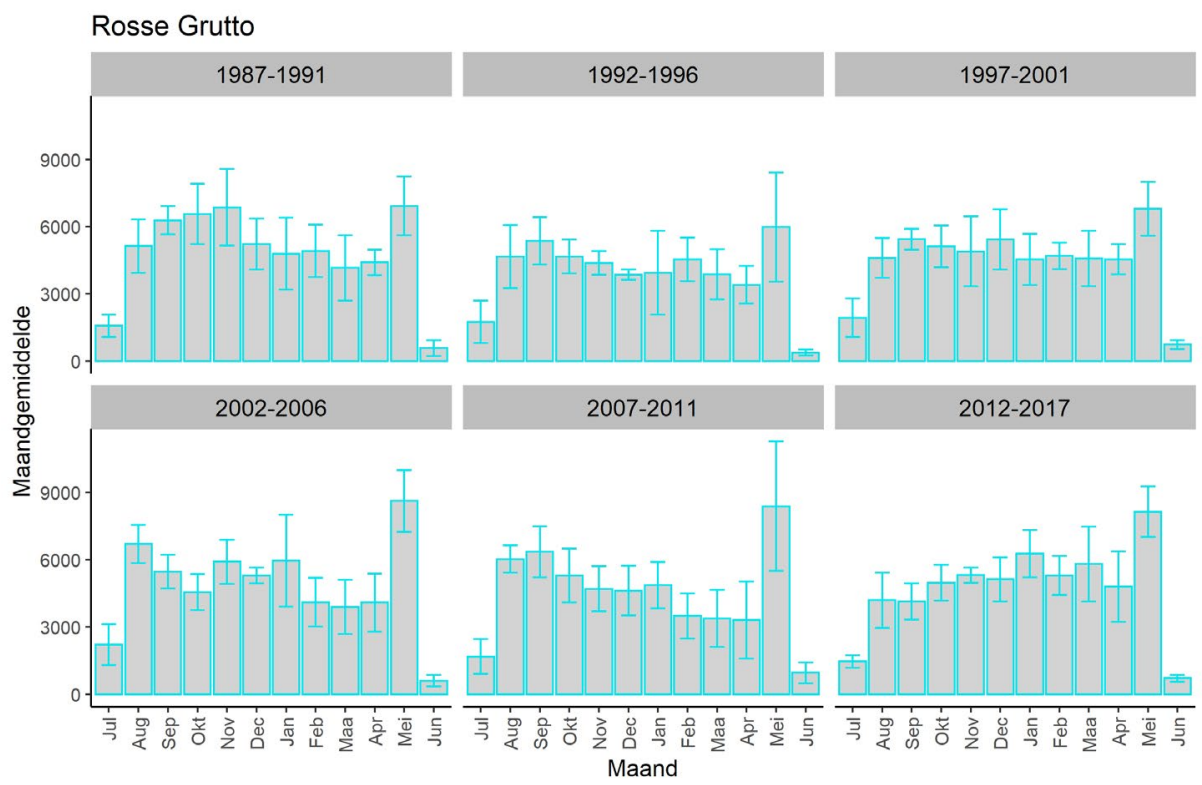

Figuur 20 Seizoenspatroon van de rosse grutto per telperiode van vier jaar. De barplots tonen het gemiddelde en de standaarddeviatie per maand.

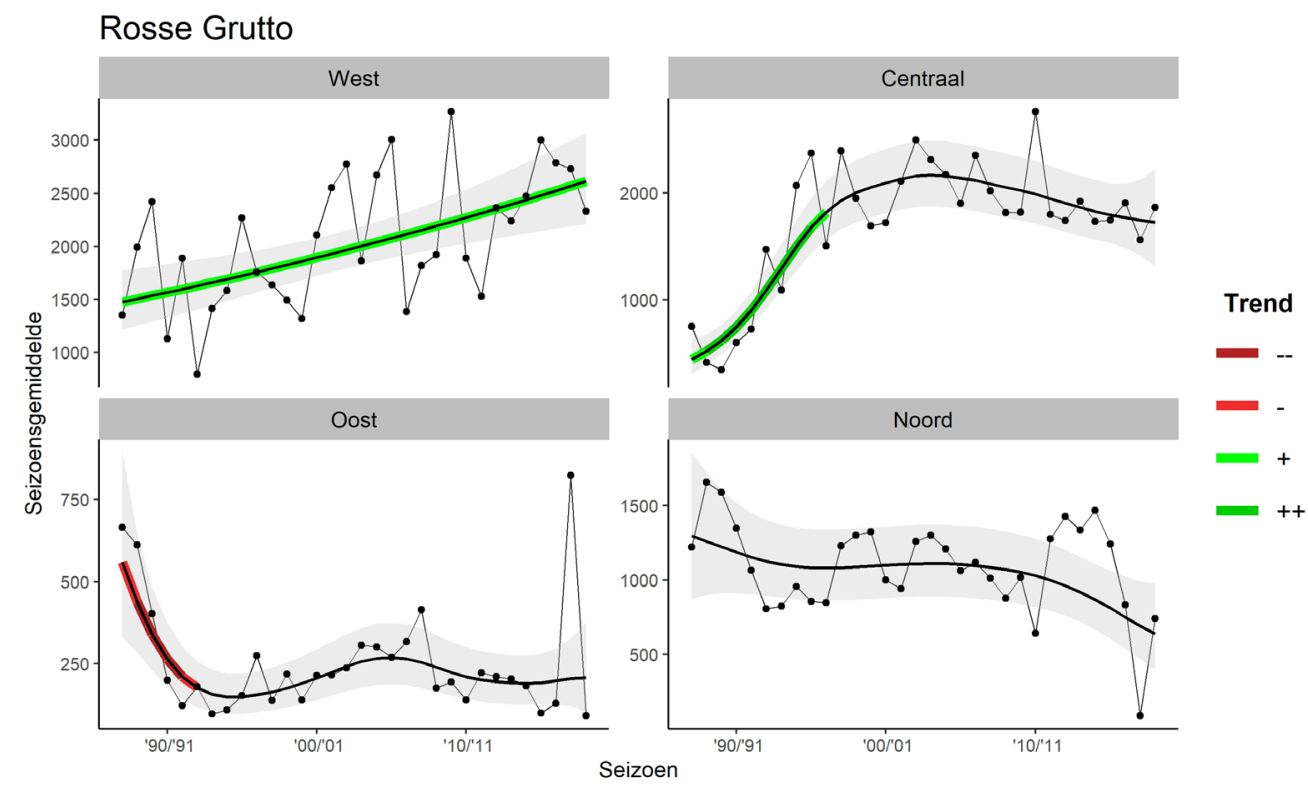

Figur 21 Trendanalyse van de gemiddelde aantallen rosse grutto's per seizoen per deelgebied in deze studie van telseizoen ' $87 /$ '88 tot en met '18/'19. De punten representeren de seizoensgemiddelden berekend over de ruwe data (ongecorrigeerde tellingen van de maanden januari, februari, mei, augustus, november, december). De dikke lijn is het geschatte populatieverloop door Trendspotter. De grijze band om deze lijn representeert het 95\% betrouwbaarheidsinterval. De kleur geeft de trendclassificatie aan. Let op het schaalverschil op de $y$-as tussen de figuren. 


\subsubsection{Kanoetstrandloper Calidris canutus}

De kanoetstrandloper is vooral in de wintermaanden in de Oosterschelde (Figuur 22). De aantallen worden daarom vooral bepaald door de ondersoort C. $c$. islandica die overwintert in Europa en broedt in Groenland en Canada (van Roomen et al. 2018). De ondersoort C. c. canutus trekt in mei door Nederland op weg naar broedgebieden in Noord Rusland en overwinteringsgebieden in West Afrika. De kanoetstrandloper is tussen 1990 en 2005 sterk toegenomen maar neemt de laatste 10-15 jaar weer sterk af. Aantallen zijn in alle deelgebieden afgenomen het laatste decennium, alhoewel dit niet allemaal significante afnames zijn (Figuur 23). De afnames zijn allemaal rond het seizoen van 20042005 ingezet. In het westelijke deelgebied zitten de minste kanoetstrandlopers, de andere deelgebieden hebben ongeveer een gelijk aantal vogels.

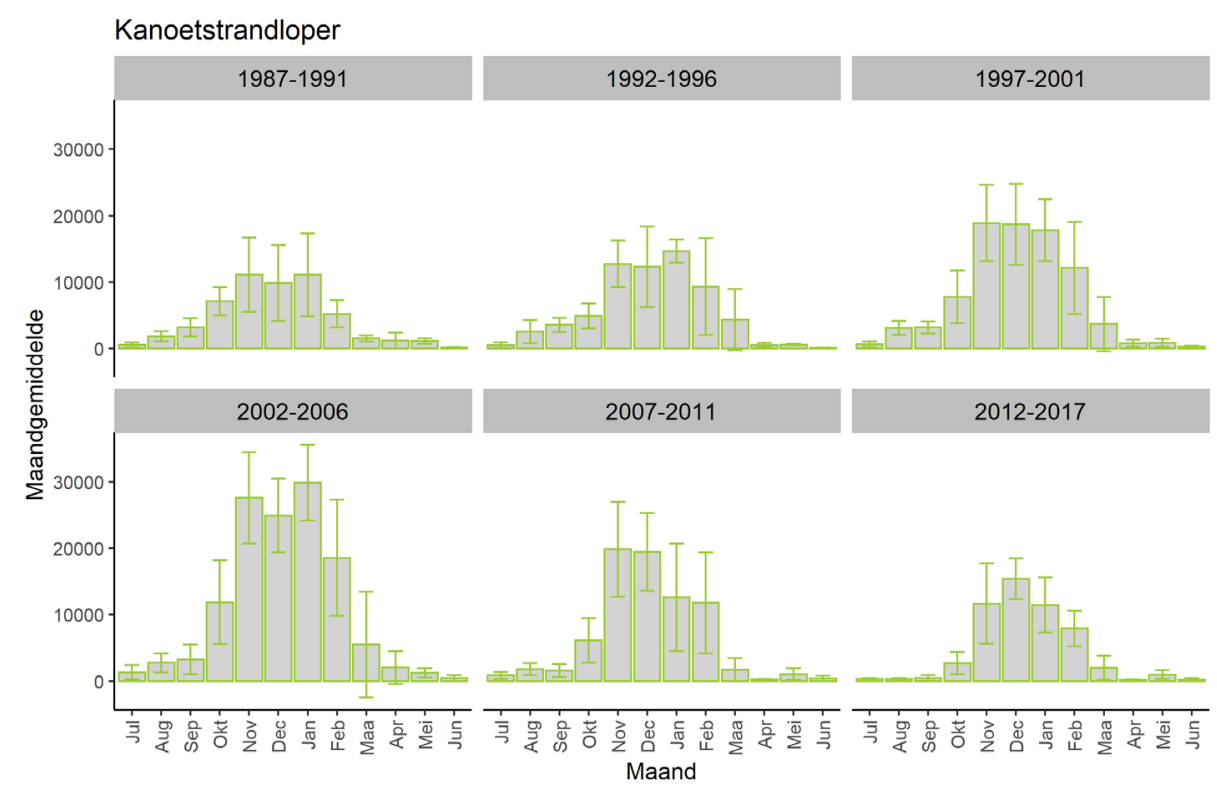

Figuur 22 Seizoenspatroon van de kanoetstrandloper per telperiode van vier jaar. De barplots tonen het gemiddelde en de standaarddeviatie per maand.

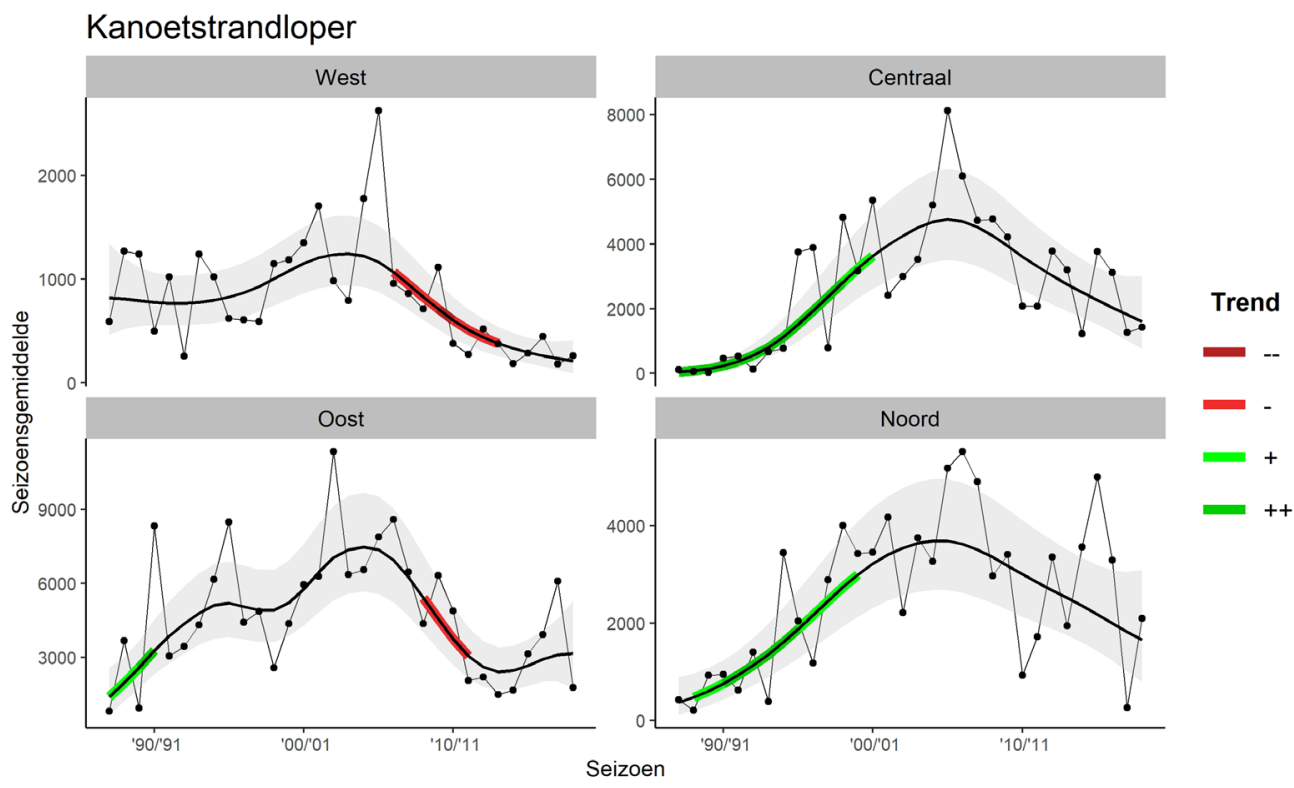

Figuur 23 Trendanalyse van de gemiddelde aantallen kanoetstrandlopers per seizoen per deelgebied van telseizoen '87/'88 tot en met '18/'19. De punten representeren de seizoensgemiddelden berekend over de ruwe data (ongecorrigeerde tellingen van de maanden januari, februari, mei, augustus, november, december). De dikke lijn is het geschatte populatieverloop door Trendspotter. De grijze band om deze lijn representeert het 95\% betrouwbaarheidsinterval. De kleur geeft de trendclassificatie aan. Let op het schaalverschil op de $y$-as tussen de figuren. 


\subsubsection{Tureluur Tringa tetanus}

Het seizoenspatroon van de tureluur heeft wat veranderingen ondergaan (Figuur 24). De piek in aantallen in de zomer- en herfstmaanden is over de jaren hoger geworden, terwijl de aantallen in de winter en lente in eerste instantie gelijk bleven. De laatste vijf jaar lijkt de piek in zomer en herfstmaanden echter bijna niet meer aanwezig. Er zijn twee ondersoorten van de tureluur die Nederland bezoeken (van Roomen et al. 2018). De T.t. robusta die broedt in IJsland en overwintert in landen aan de Noordzee en Frankrijk en de T.t. totanus. Deze ondersoort heeft een aantal verschillende vliegroutes en overwinter- en broedplaatsen waaronder een deel dat broedt in GrootBrittanië, Ierland en Nederland en alleen over korte afstanden migreert maar een deel ook broedt in Scandinavië en Baltische staten en overwintert aan de Atlantische kust van Spanje, Portugal, Noorden West-Afrika. De trends in de deelgebieden laten een tweeledig beeld zien (Figuur 25); aantallen in West en Noord zijn met name in de beginperiode toegenomen, terwijl de aantallen in Centraal en West meer schommelen, met in beide gebieden een duidelijke piek rond telseizoen 2005/2006.

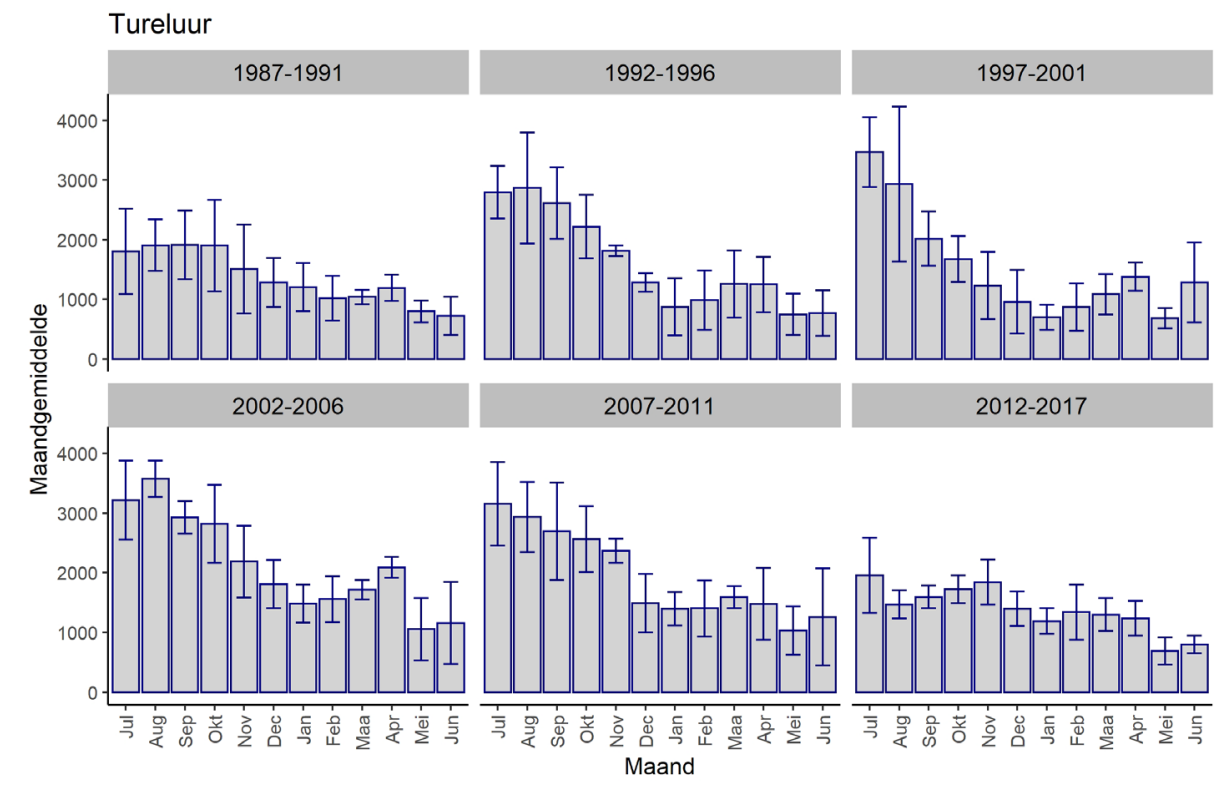

Figuur 24 Seizoenspatroon van de tureluur per telperiode van vier jaar. De barplots tonen het gemiddelde en de standaarddeviatie per maand.

Tureluur
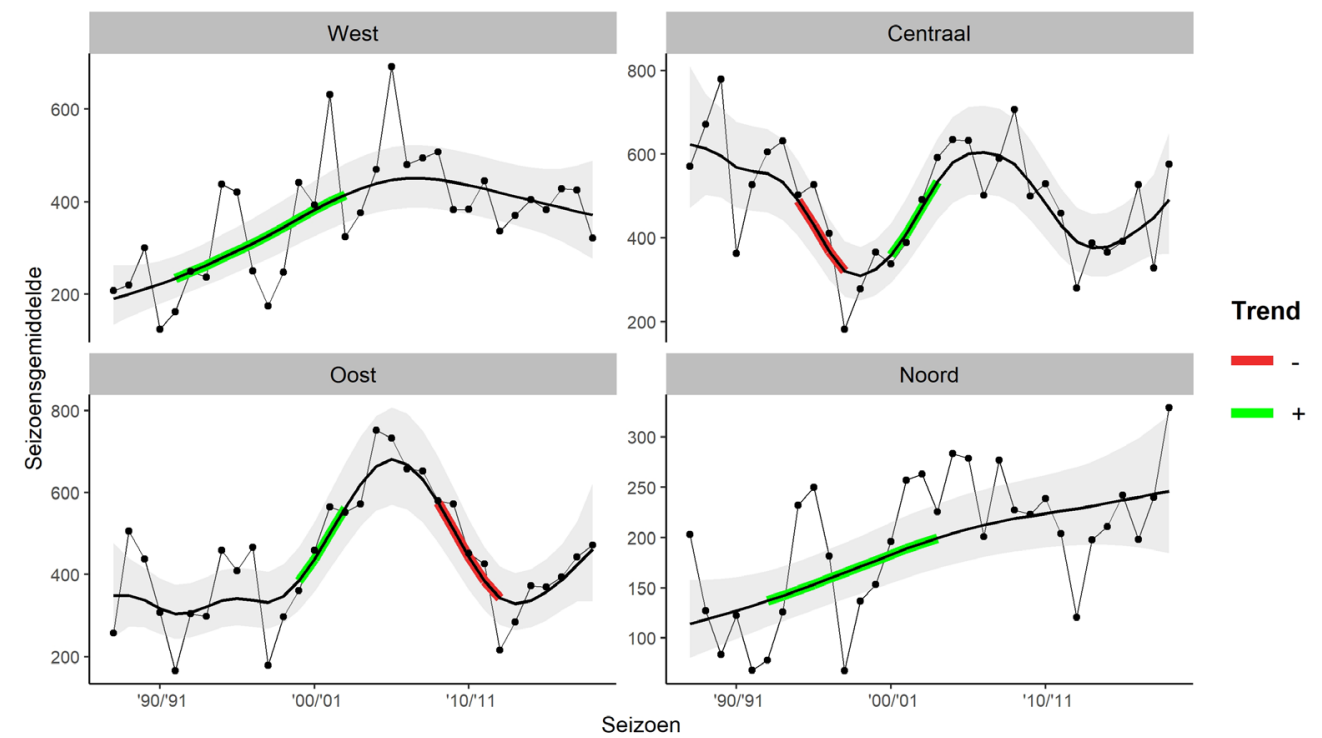

Figur 25 Trendanalyse van de gemiddelde aantallen tureluurs per seizoen per deelgebied van telseizoen '87/'88 tot en met '18/'19. De punten representeren de seizoensgemiddelden berekend over de ruwe data (ongecorrigeerde tellingen van de maanden januari, februari, mei, augustus, november, december). De dikke lijn is het geschatte populatieverloop door Trendspotter. De grijze band om deze lijn representeert het $95 \%$ betrouwbaarheidsinterval. De kleur geeft de trendclassificatie aan. Let op het schaalverschil op de $y$-as tussen de figuren. 


\subsubsection{Zilverplevier Pluvialis squatarola}

De zilverplevier is op uitzondering van juni en juli in de Oosterschelde te vinden. In de wintermaanden zijn de aantallen stabiel en in de migratietijd is een kleine piek te zien herfst en voorjaar, vooral in mei (Figuur 26). In Nederland is alleen de ondersoort Pluvialis squatarola squatarola te vinden die broedt in Noord-Rusland en overwintert in Noordwest-Europa maar ook in West-Afrika. Aantallen nemen al vanaf het begin van de telperiode toe in het westelijk deelgebied, net als in Noord vooral in het begin van de telperiode (Figuur 27). De aantallen in het centrale deelgebied namen eerst sterk toe, maar zijn nu gestabiliseerd. In Oost zijn de minste zilverplevieren geteld en zijn de aantallen min of meer stabiel.

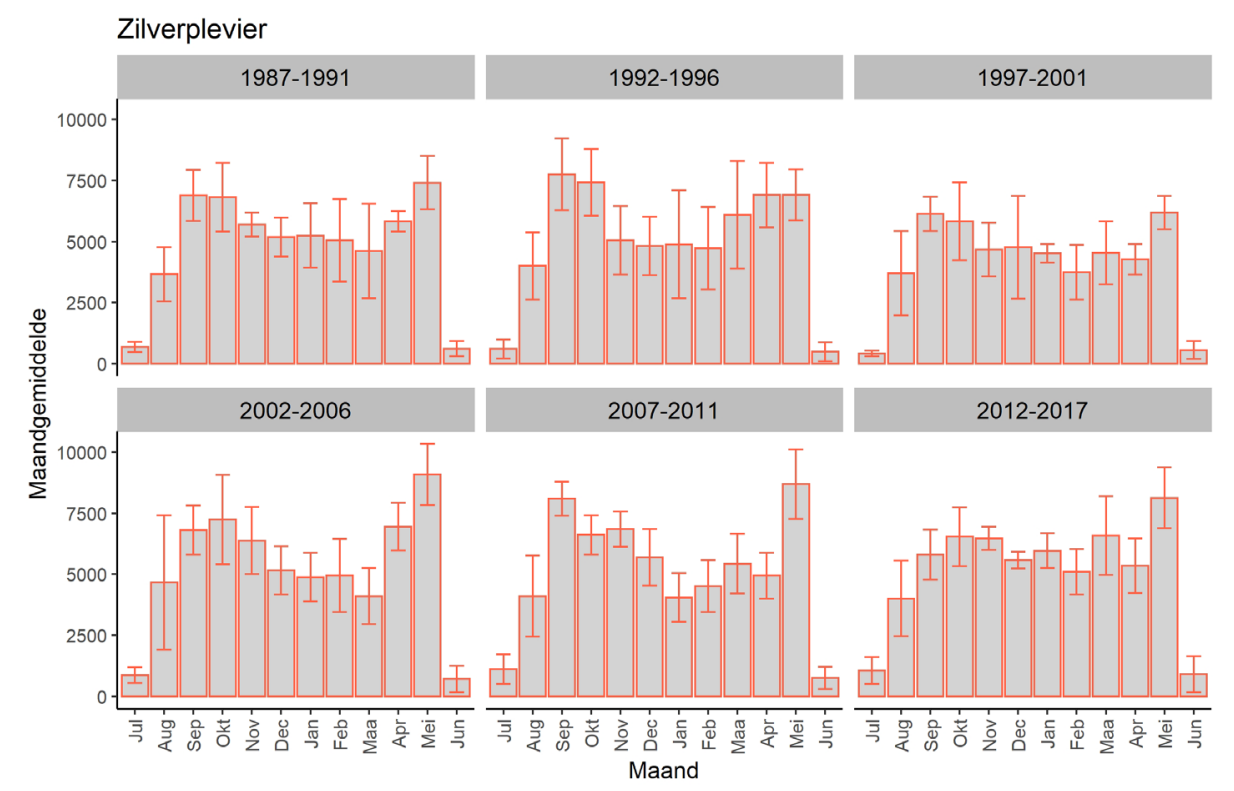

Figuur 26 Seizoenspatroon van de zilverplevier per telperiode van vier jaar. De barplots tonen het gemiddelde en de standaarddeviatie per maand.

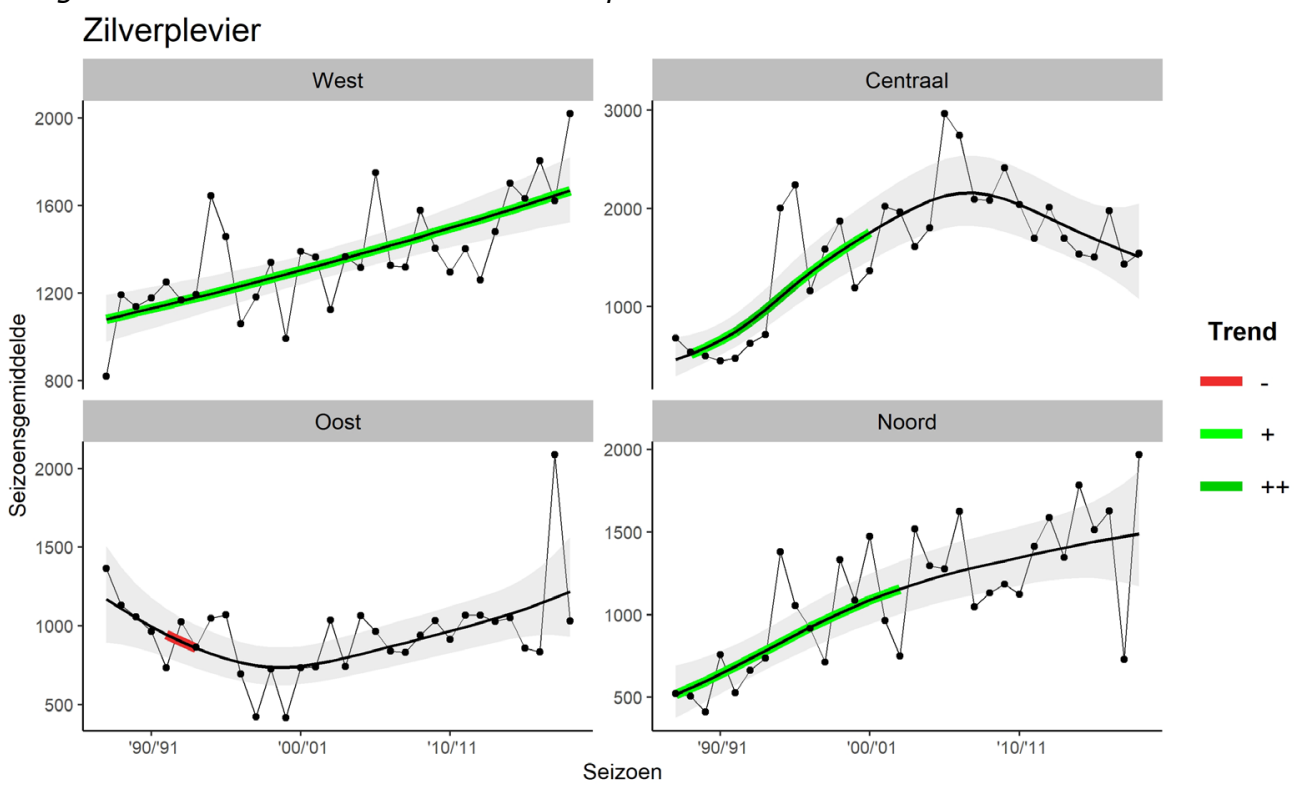

Figuur 27 Trendanalyse van de gemiddelde aantallen zilverplevieren per seizoen per deelgebied van telseizoen ' $87 /$ '88 tot en met '18/'19. De punten representeren de seizoensgemiddelden berekend over de ruwe data (ongecorrigeerde tellingen van de maanden januari, februari, mei, augustus, november, december). De dikke lijn is het geschatte populatieverloop door Trendspotter. De grijze band om deze lijn representeert het $95 \%$ betrouwbaarheidsinterval. De kleur geeft de trendclassificatie aan. Let op het schaalverschil op de $y$-as tussen de figuren. 


\subsubsection{Steenloper Arenaria interpres}

Het seizoenspatroon van de steenloper ziet er hetzelfde uit als voor de zilverplevier. De soort is jaarrond te vinden in de Oosterschelde, met uitzondering van de broedtijd in juni en juli (Figuur 28). De soort heeft twee subpopulaties, de eerste broedt in Noord-Scandinavië en West-Rusland en de tweede broedt in Noordoost-Canada en Groenland en overwintert in West-Europa (van Roomen et al. 2018). De laatste bepaalt vooral de aantallen in de Oosterschelde, alhoewel er in de meeste telperiodes een duidelijke migratiepiek te zien is in het najaar. De deelgebieden laten een zeer wisselend beeld zien (Figuur 28). In Noord zijn de aantallen stabiel, in West nemen de aantallen iets af, in het centrale deelgebied schommelen de aantallen met periodes met significante toe- en afnames en in Oost, waar de meeste steenlopers zijn geteld, zijn de aantallen significant toegenomen vanaf het jaar $\sim 2000$ tot $\sim 2008$.

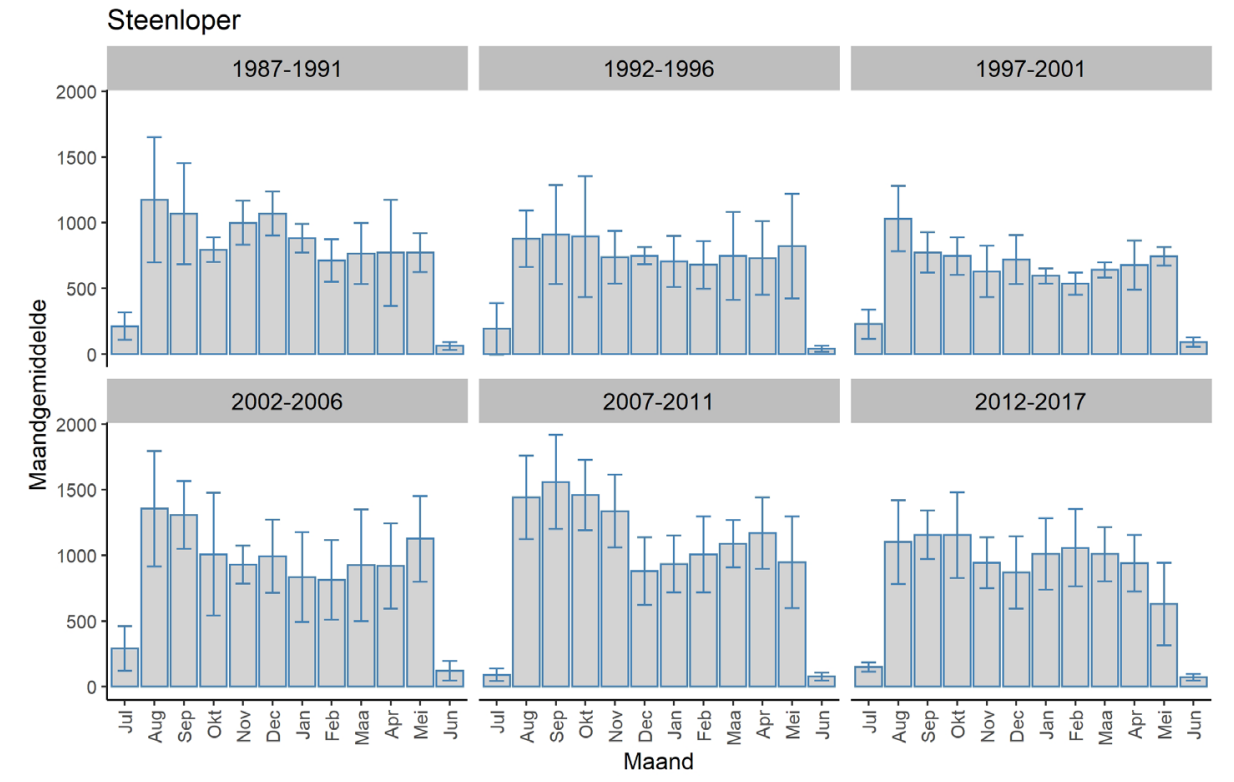

Figuur 28 Seizoenspatroon van de steenloper per telperiode van vier jaar. De barplots tonen het gemiddelde en de standaarddeviatie per maand.
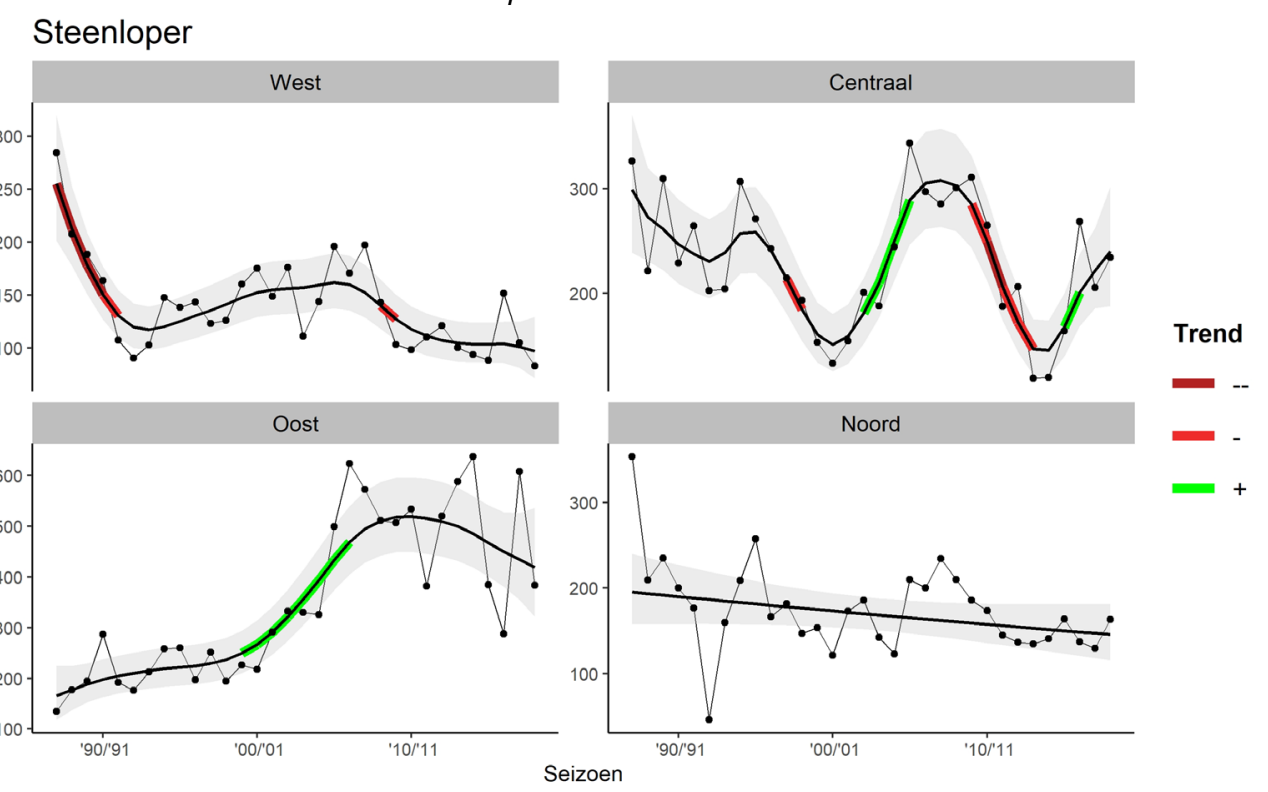

Figuur 29 Trendanalyse van de gemiddelde aantallen steenlopers per seizoen per deelgebied van telseizoen '87/'88 tot en met '18/'19. De punten representeren de seizoensgemiddelden berekend over de ruwe data (ongecorrigeerde tellingen van de maanden januari, februari, mei, augustus, november, december). De dikke lijn is het geschatte populatieverloop door Trendspotter. De grijze band om deze lijn representeert het $95 \%$ betrouwbaarheidsinterval. De kleur geeft de trendclassificatie aan. Let op het schaalverschil op de $y$-as tussen de figuren. 


\subsubsection{Bonte strandloper Calidris alba}

Ook bonte strandlopers zijn echte wintergasten in Nederland. Met name de laatste jaren, zijn de hoogste aantallen in de Oosterschelde te vinden van oktober tot januari (Figuur 30). Aantallen worden vooral bepaald door de ondersoort Calidris alpine alpina die broedt in Noord-Scandinavië en NoordRusland en vooral overwintert in West-Europa (van Roomen et al. 2018). De andere twee ondersoorten C.a. arctica en C.a. schinzii passeren de Oosterschelde mogelijk in de migratietijd. Na een sterke toename in vooral het begin van de telperiode, zijn de aantallen bonte strandloper de afgelopen jaren gestabiliseerd. In het westelijk deel zitten iets minder vogels dan in de andere deelgebieden, de meeste vogels zitten in deelgebied Oost (Figuur 31).

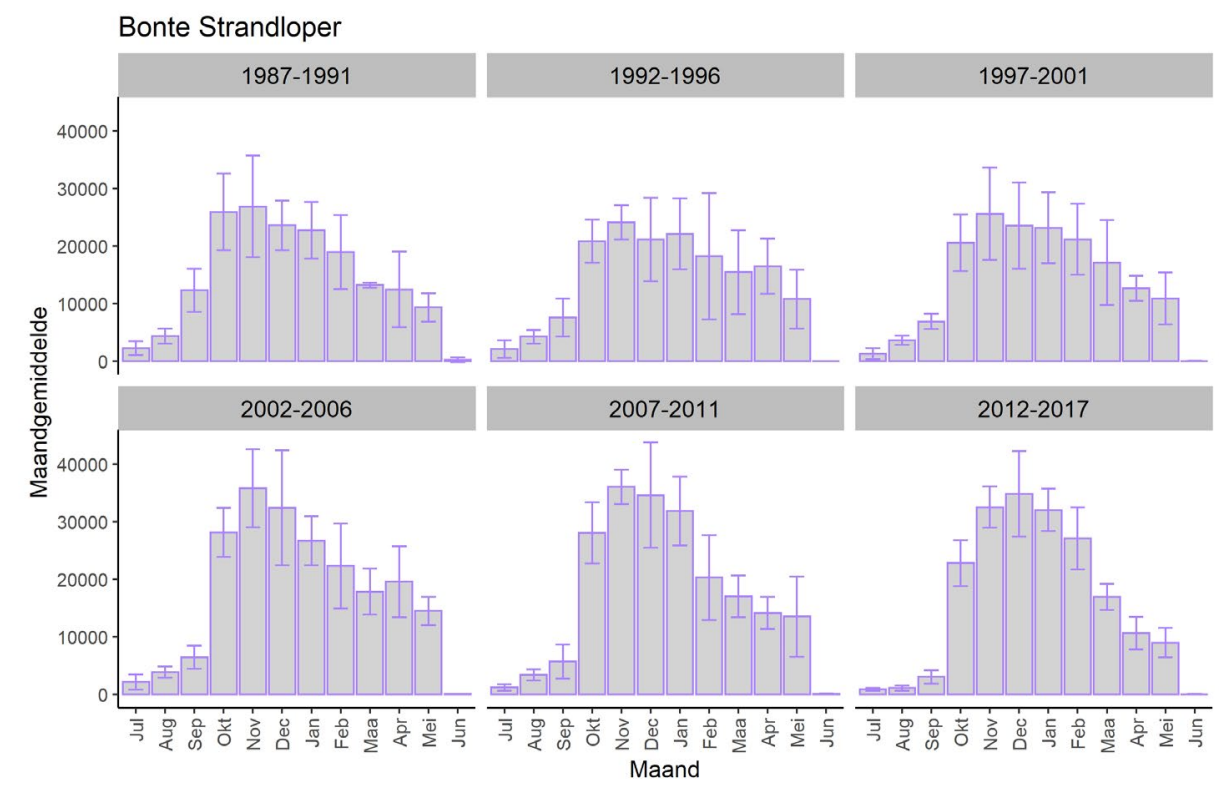

Figuur 30 Seizoenspatroon van de bonte strandloper per telperiode van vier jaar. De barplots tonen het gemiddelde en de standaarddeviatie per maand.

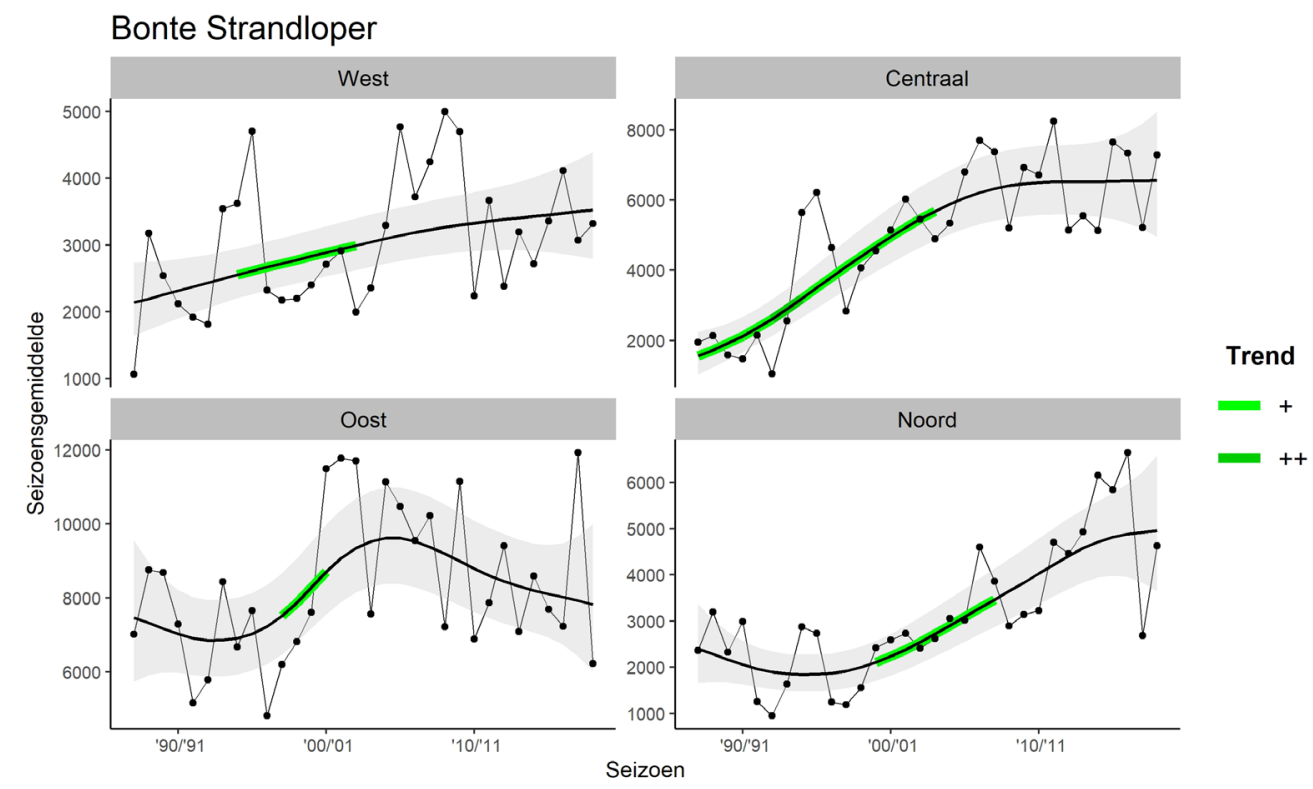

Figuur 31 Trendanalyse van de gemiddelde aantallen bonte strandlopers per seizoen per deelgebied van telseizoen ' $87 /$ '88 tot en met '18/'19. De punten representeren de seizoensgemiddelden berekend over de ruwe data (ongecorrigeerde tellingen van de maanden januari, februari, mei, augustus, november, december). De dikke lijn is het geschatte populatieverloop door Trendspotter. De grijze band om deze lijn representeert het $95 \%$ betrouwbaarheidsinterval. De kleur geeft de trendclassificatie aan. Let op het schaalverschil op de $y$-as tussen de figuren. 


\subsubsection{Bergeend Tadorna tadorna}

Bergeenden zijn het hele jaar door in Nederland waar ze ook broeden, net als in noordelijke landen zoals Noorwegen, IJsland, landen aan de Noord- en Oostzee en in mindere mate in Frankrijk en Spanje (van Roomen et al. 2018). Bergeenden zijn gedeeltelijk trekvogels en overwinteringsgebieden overlappen met broedgebieden. De Oosterschelde is vooral een overwinteringsplaats met een piek in aantallen van december tot maart (Figuur 32). De meeste bergeenden komen voor in het oostelijk deelgebied. Aantallen bergeenden bereikten een piek rond het jaar 2000 door toenames in het centrale, westelijke en oostelijke deelgebied (Figuur 33). Aantallen zijn in het centrale en oostelijke deel sindsdien iets afgenomen maar zijn nog steeds hoger dan in het begin van de telperiode. De aantallen groeien significant in het westelijk en meer recentelijk ook in het oostelijk deelgebied. In Noord lijken de bergeenden recentelijk ook toe te nemen, maar in Centraal zijn de aantallen stabiel of nemen zelfs iets af.

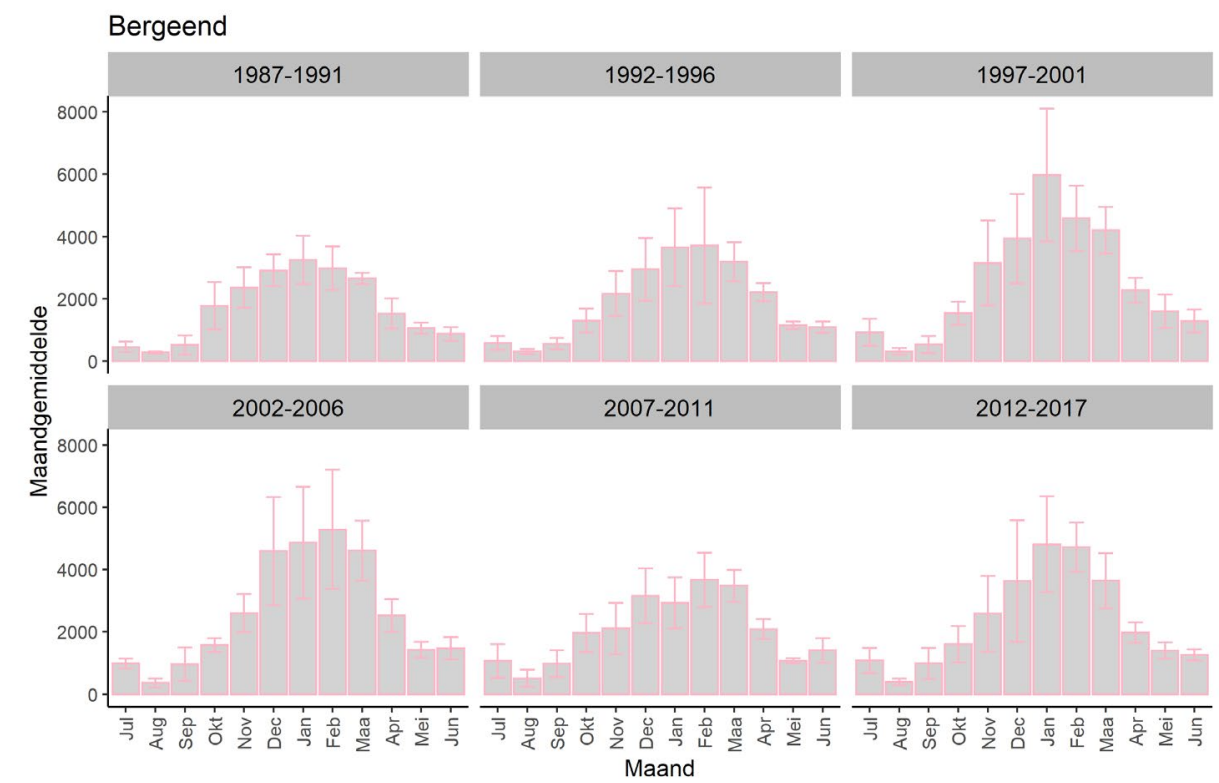

Figuur 32 Seizoenspatroon van de bergeend per telperiode van vier jaar. De barplots tonen het gemiddelde en de standaarddeviatie per maand.

Bergeend
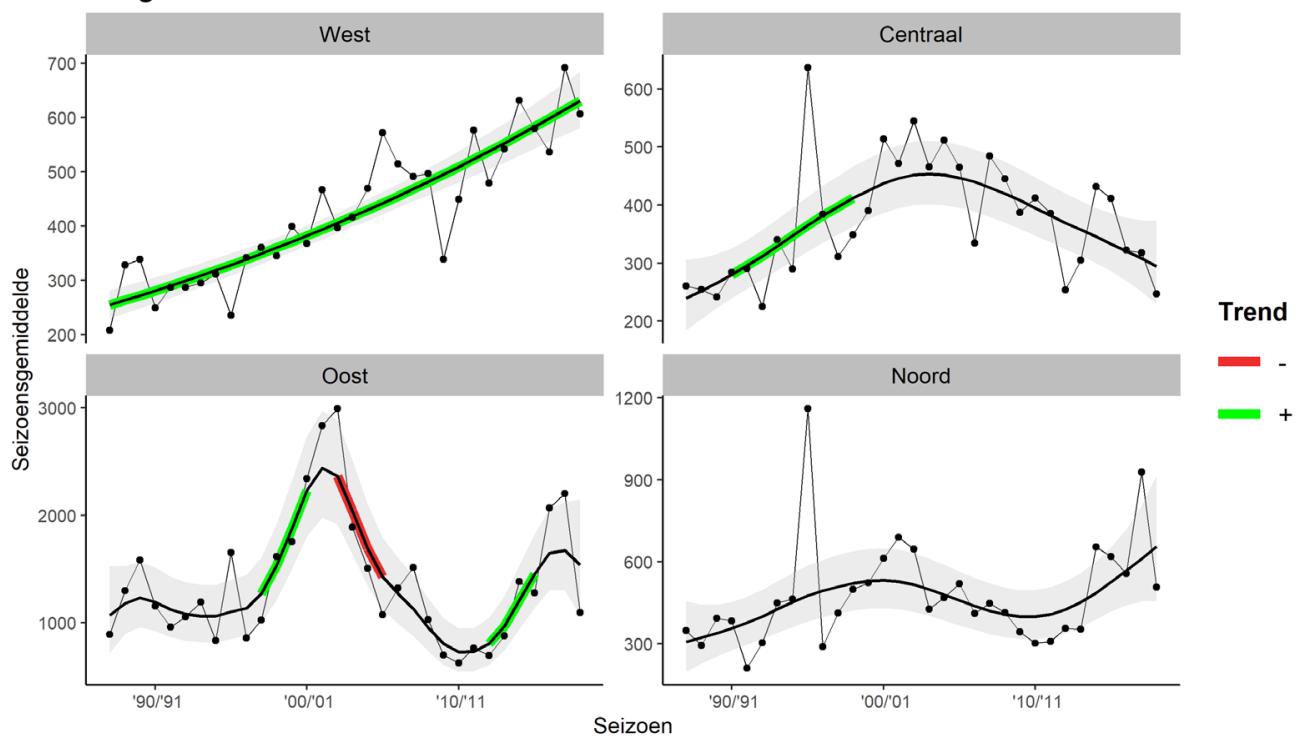

Figuur 33 Trendanalyse van de gemiddelde aantallen bergeenden per seizoen per deelgebied van telseizoen '87/'88 tot en met '18/'19. De punten representeren de seizoensgemiddelden berekend over de ruwe data (ongecorrigeerde tellingen van de maanden januari, februari, mei, augustus, november, december). De dikke lijn is het geschatte populatieverloop door Trendspotter. De grijze band om deze lijn representeert het $95 \%$ betrouwbaarheidsinterval. De kleur geeft de trendclassificatie aan. Let op het schaalverschil op de $y$-as tussen de figuren. 


\subsubsection{Kluut Recurvirostra avosetta}

De kluut is jaarrond in de Oosterschelde aanwezig, maar aantallen pieken in het voorjaar van april tot juni (Figuur 34). Het seizoenspatroon is over de tijd iets verandert. De soort is sinds 1990 sterk toegenomen, maar vooral de voorjaarspiek is toegenomen (april-juni). De kluten die in West Europa broeden, migreren in de winter naar Zuidwest-Europa en West-Afrika, maar zoals te zien is in Figuur 34 overwintert ook een deel in Nederland en de Oosterschelde (van Roomen et al. 2018). Kluten zijn in alle deelgebieden toegenomen (Figuur 35). De groei is in West en Centraal gestabiliseerd. In deelgebied Oost en Noord zijn aantallen meer variabel, in Oost lijken aantallen iets af te nemen het laatste decennium, in Noord groeien de aantallen in het laatste decennium weer. De grootste aantallen kluten zitten in het westelijk deelgebied.

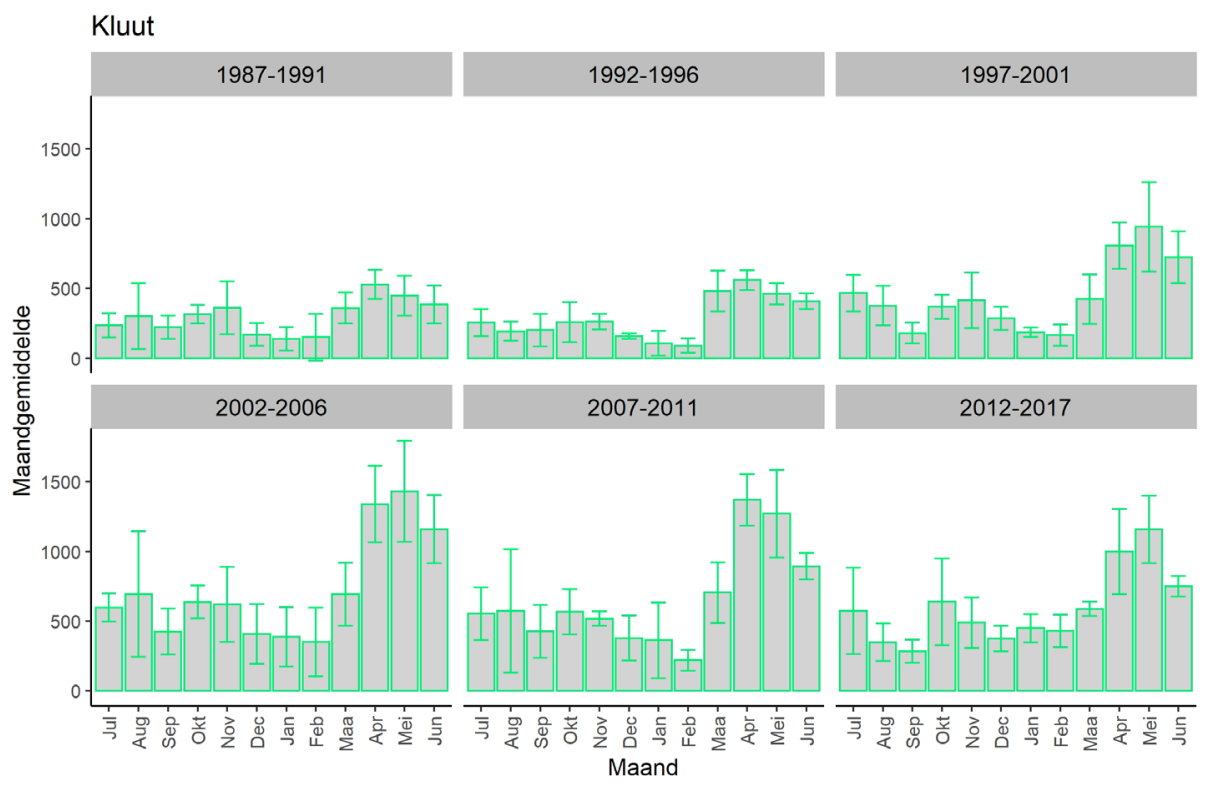

Figuur 34 Seizoenspatroon van de kluut per telperiode van vier jaar. De barplots tonen het gemiddelde en de standaarddeviatie per maand.

Kluut
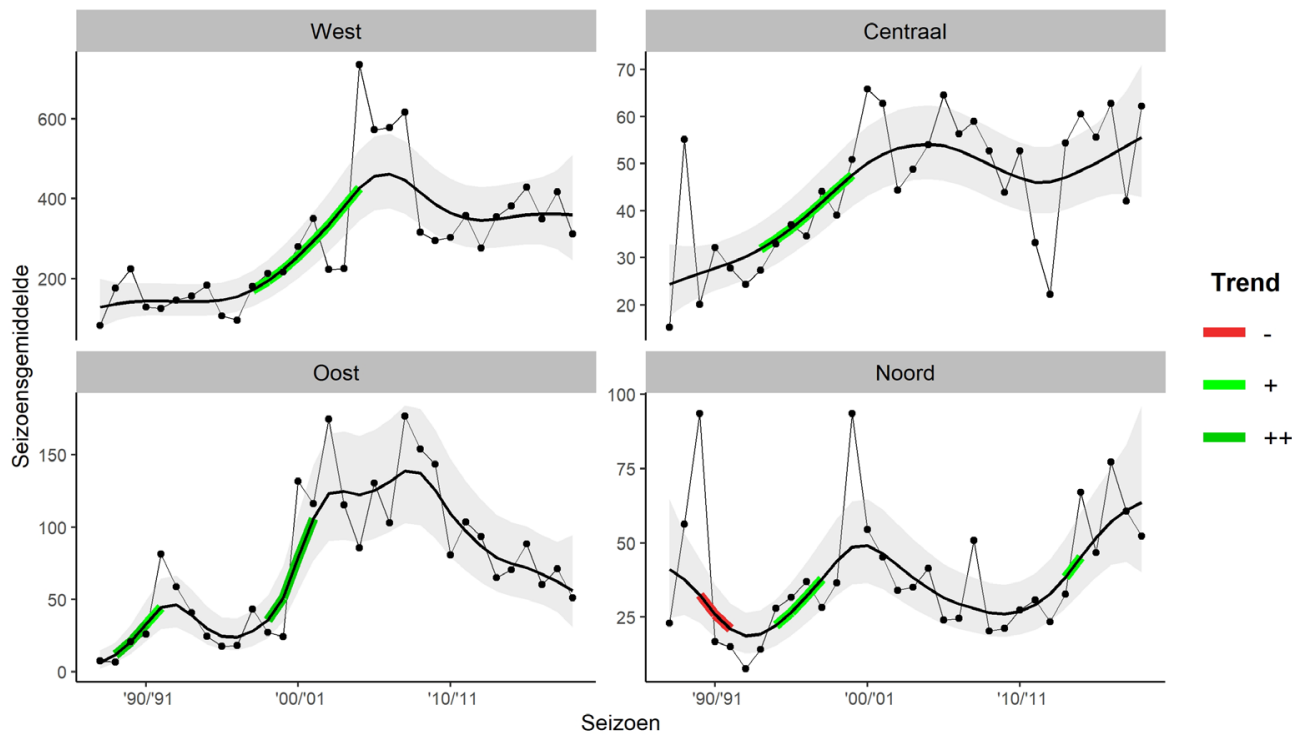

Figuur 35 Trendanalyse van de gemiddelde aantallen kluten per seizoen per deelgebied van telseizoen '87/'88 tot en met '18/'19. De punten representeren de seizoensgemiddelden berekend over de ruwe data (ongecorrigeerde tellingen van de maanden januari, februari, mei, augustus, november, december). De dikke lijn is het geschatte populatieverloop door Trendspotter. De grijze band om deze lijn representeert het $95 \%$ betrouwbaarheidsinterval. De kleur geeft de trendclassificatie aan. Let op het schaalverschil op de $y$-as tussen de figuren. 


\subsubsection{Wulp Numenius arquata}

De wulp is in grote aantallen aanwezig in de Oosterschelde van augustus tot maart, maar heeft een piek in augustus tot oktober (Figuur 36). De soort broedt in grote delen van Europe waaronder Nederland, maar dit gebeurt vooral in het oosten van het land (Troost and Ysebaert 2011). In het broedseizoen zijn er dan ook weinig wulpen in de Oosterschelde. De soort overwintert deels in Nederland, Verenigd Koninkrijk en Frankrijk, Zuid-Europa en West-Afrika. De piek in aantallen in de herfst wordt hoogstwaarschijnlijk veroorzaakt door migrerende wulpen die broeden in noordelijkere landen (Strucker et al. 2010). De wulp is over de gemonitorde periode in alle deelgebieden sterk toegenomen (Figuur 37). Aantallen nemen ook nu nog toe, alhoewel niet overal significant. De wulpen in deelgebied Oost lijken te zijn gestabiliseerd. De meeste wulpen zitten in het centrale deelgebied, de minste in deelgebied Noord.

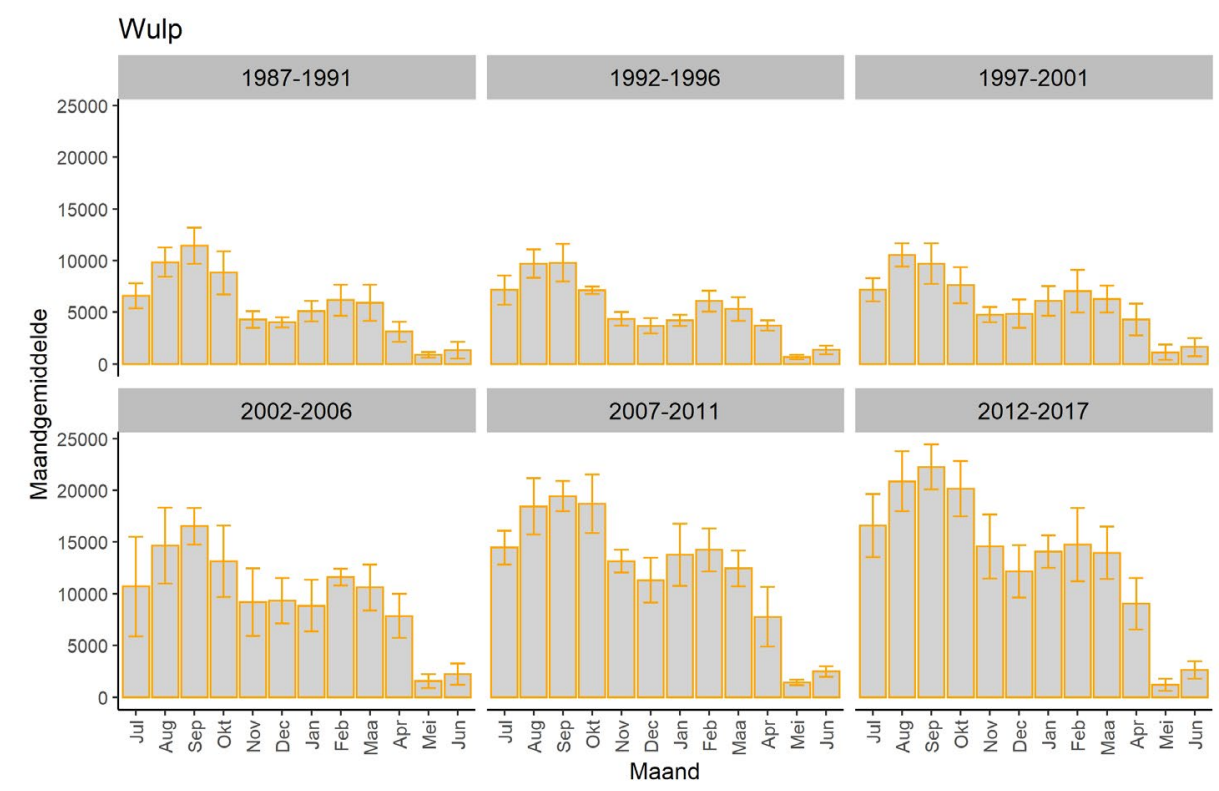

Figuur 36 Seizoenspatroon van de wulp per telperiode van vier jaar. De barplots tonen het gemiddelde en de standaarddeviatie per maand.

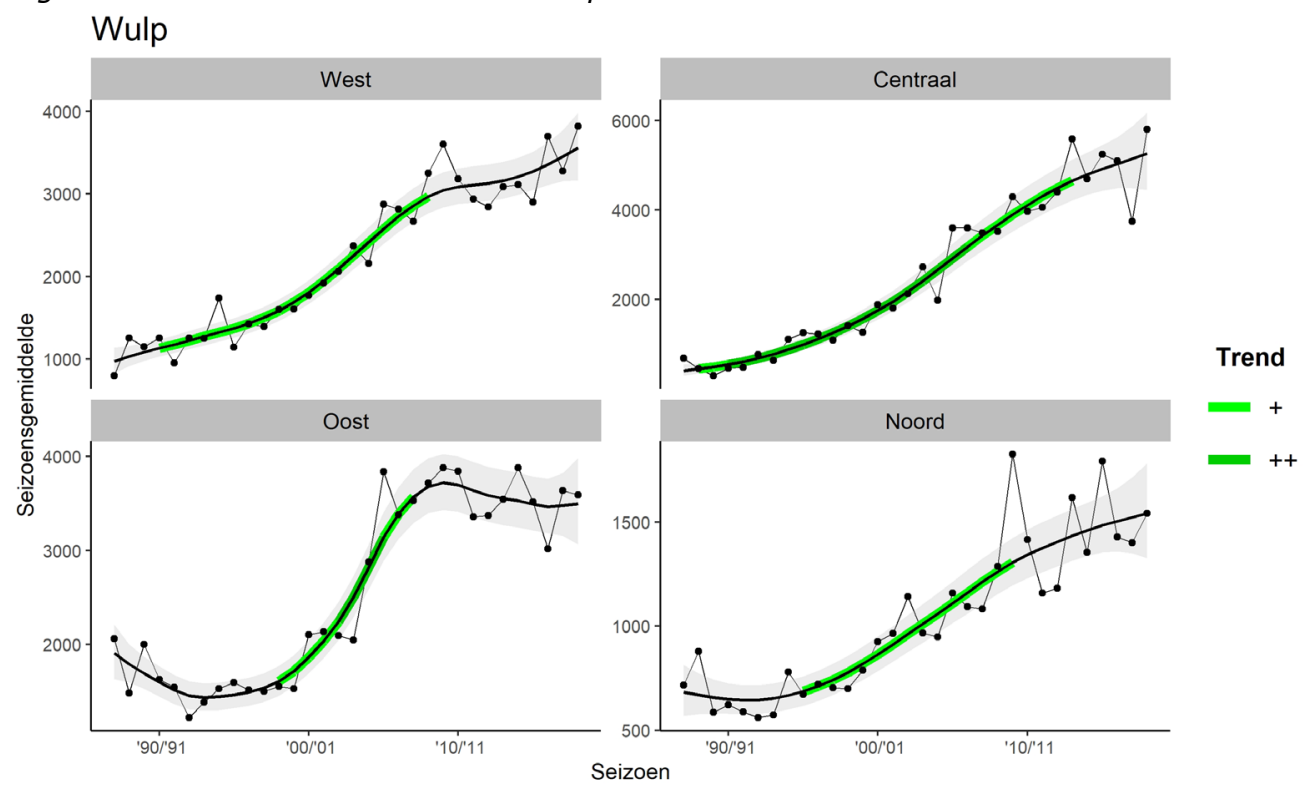

Figuur 37 Trendanalyse van de gemiddelde aantallen wulpen per seizoen per deelgebied van telseizoen '87/'88 tot en met '18/'19. De punten representeren de seizoensgemiddelden berekend over de ruwe data (ongecorrigeerde tellingen van de maanden januari, februari, mei, augustus, november, december). De dikke lijn is het geschatte populatieverloop door Trendspotter. De grijze band om deze lijn representeert het $95 \%$ betrouwbaarheidsinterval. De kleur geeft de trendclassificatie aan. Let op het schaalverschil op de $y$-as tussen de figuren. 


\subsubsection{Drieteenstrandloper Calidris alba}

Een duidelijk seizoenspatroon is te zien in de tellingen, met aantallen die pieken in de migratietijd van augustus tot oktober en in mei (Figuur 38). De soort broedt in Groenland en Noordoost-Canada, maar ook in noordelijk Europa en Rusland. De overwinteringsgebieden strekken zich uit van Europa langs de Westkust van Afrika tot Zuid-Afrika. Het westelijk deelgebied bevat de meeste drieteenstrandlopers. De drieteenstrandloper is het sterkst toegenomen van de soorten die besproken worden in deze rapportage. De sterke toename is alleen te zien in deelgebieden West en Centraal, in de andere deelgebieden zitten zeer weinig tot geen drieteenstrandlopers (Figuur 39). De laatste jaren zijn de aantallen stabiel.

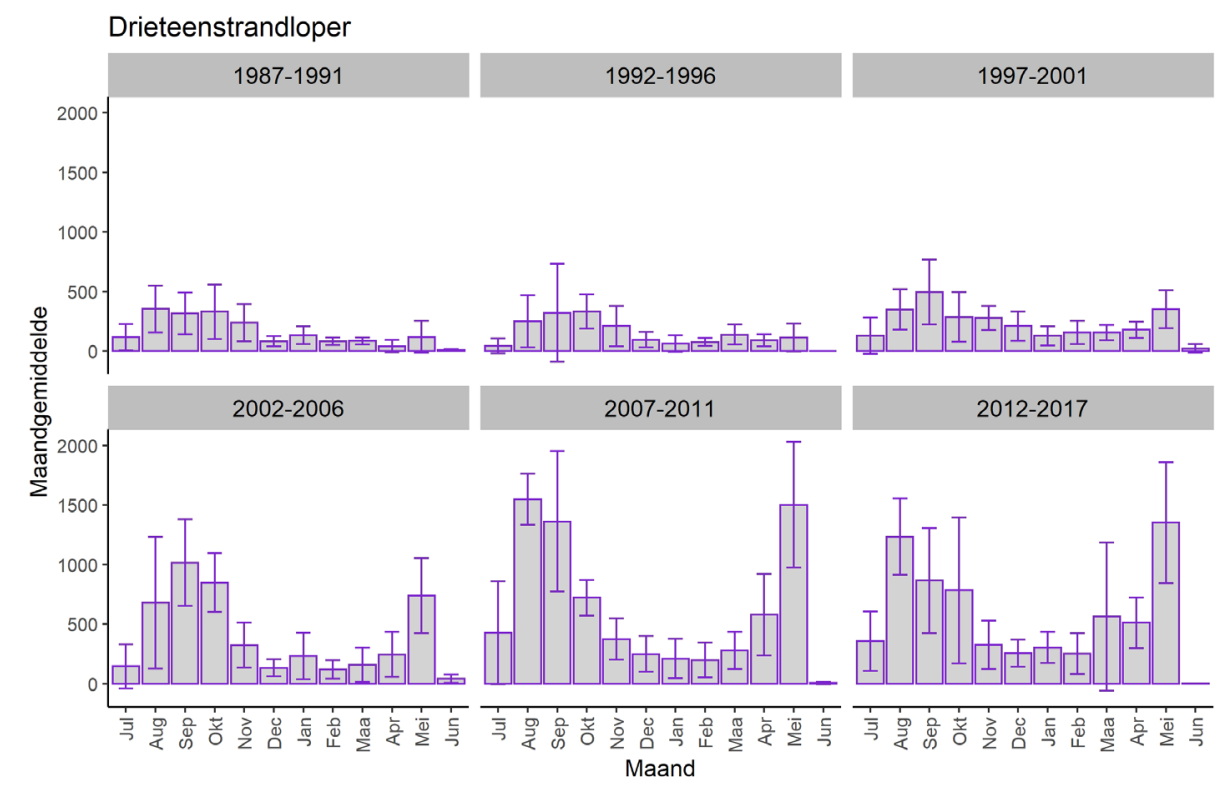

Figuur 38 Seizoenspatroon van de drieteenstrandloper per telperiode van vier jaar. De barplots tonen het gemiddelde en de standaarddeviatie per maand.

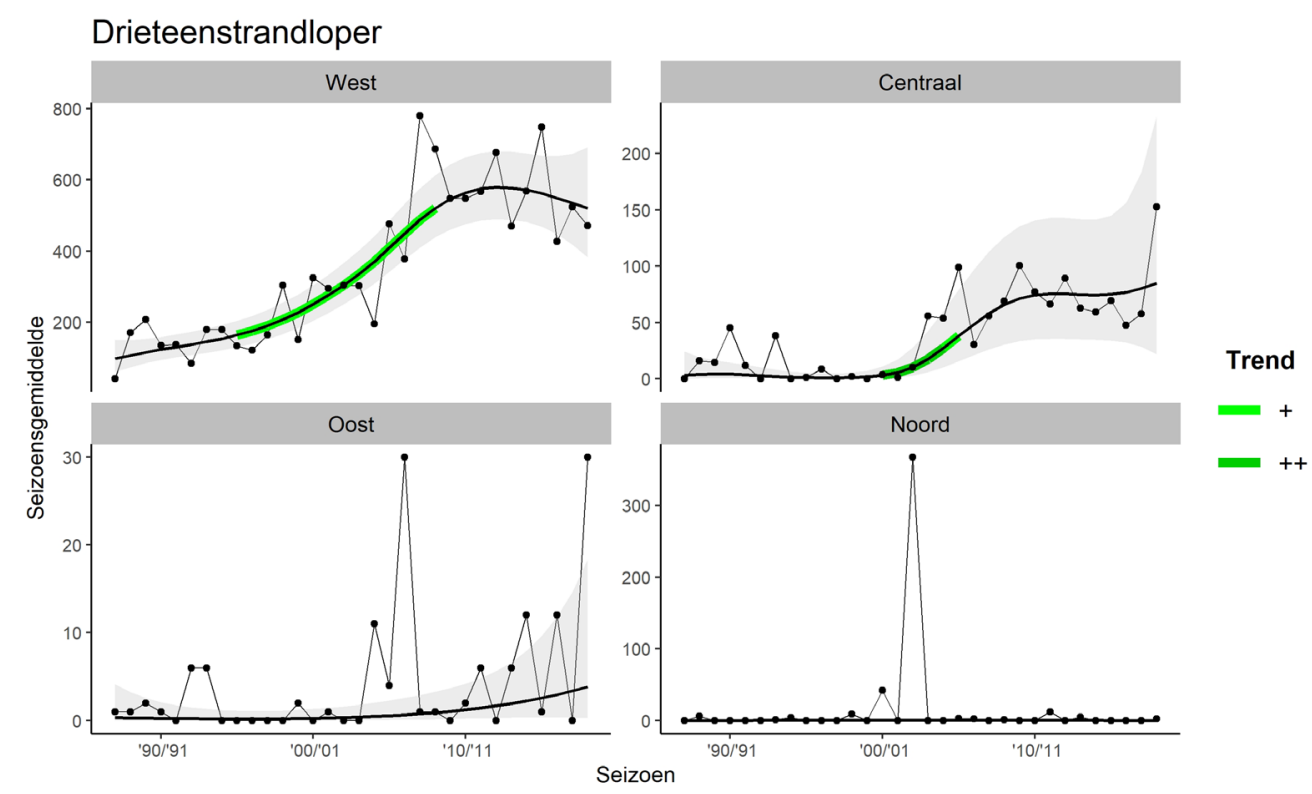

Figuur 39 Trendanalyse van de gemiddelde aantallen drieteenstrandlopers per seizoen per deelgebied van telseizoen ' $87 /$ '88 tot en met '18/'19. De punten representeren de seizoensgemiddelden berekend over de ruwe data (ongecorrigeerde tellingen van de maanden januari, februari, mei, augustus, november, december). De dikke lijn is het geschatte populatieverloop door Trendspotter. De grijze band om deze lijn representeert het $95 \%$ betrouwbaarheidsinterval. De kleur geeft de trendclassificatie aan. Let op het schaalverschil op de $y$-as tussen de figuren. 


\subsubsection{Trends ten opzichte van de Waddenzee en de flyway}

In Figuur 41 zijn de toe- en afnames van de steltlopers te zien ten opzichte van de trends in de waddenzee (Kleefstra et al. 2019). De lange-termijntrend in de Waddenzee (links), van telseizoen ' $87 /$ '88 tot ' $16 /$ ' 17 , is vrij vergelijkbaar met de lange-termijntrend over dezelfde periode in de Oosterschelde. De meeste punten liggen in de buurt van de gestippelde lijn. Een soort die het duidelijk slechter doet in de Oosterschelde is de strandplevier. De kluut doet het daarentegen veel beter in de Oosterschelde op de lange termijn. Ook de wulp en de bergeend doen het iets beter. Op de korte termijn (vanaf telseizoen '07/'08 voor Oosterschelde en vanaf '08/'09 voor Waddenzee) gaat het met meer soorten slechter in de Oosterschelde dan in de Waddenzee (Figuur 41, rechts). De strandplevier, en steenloper zijn achteruit gegaan in de Oosterschelde terwijl ze vooruit zijn gegaan in de Waddenzee de laatste jaren. De kanoetstrandloper is hard achteruit gegaan in de Oosterschelde maar stabiel gebleven in de Waddenzee. Zwarte ruiter en tureluur gaan harder achteruit in de Oosterschelde dan in de Waddenzee. De drieteenstrandloper neemt in beide gebieden toe, maar neemt veel sterker toe in de Waddenzee.

In Figuur 41 zijn de toe- en afnames van de steltlopers te zien ten opzichte van de flyway (van Roomen et al. 2018). De lange-termijntrend in de flyway (links), lopend van telseizoen ' $87 /$ ' 88 tot '16/'17, is vrij vergelijkbaar met de lange-termijntrend over dezelfde periode in de Oosterschelde. Een soort die harder achteruit gaat in de Oosterschelde vergeleken met de flyway op de lange termijn is de strandplevier. Ook de scholekster is in de Oosterschelde harder achteruit gegaan dan in de gehele flyway. De drieteenstrandloper en wulp doen het op de lange termijn juist iets beter in de Oosterschelde. De korte-termijntrends in de Oosterschelde (telseizoen '07/'08 tot '16/'17) wijken meer af van de trends in de flyway. Meer soorten liggen boven de stippellijn, wat betekent dat de trend in de Oosterschelde negatiever is dan de flyway. Dit geldt met name voor de kanoetstrandloper en de bonte strandloper maar ook voor de groenpootruiter en steenloper gaan harder achteruit in de Oosterschelde. De kluut en bontbekplevier nemen toe in de flyway maar af in de Oosterschelde. Met name de wulp doet het in de Oosterschelde juist iets beter dan de korte-termijntrend in de flyway. 

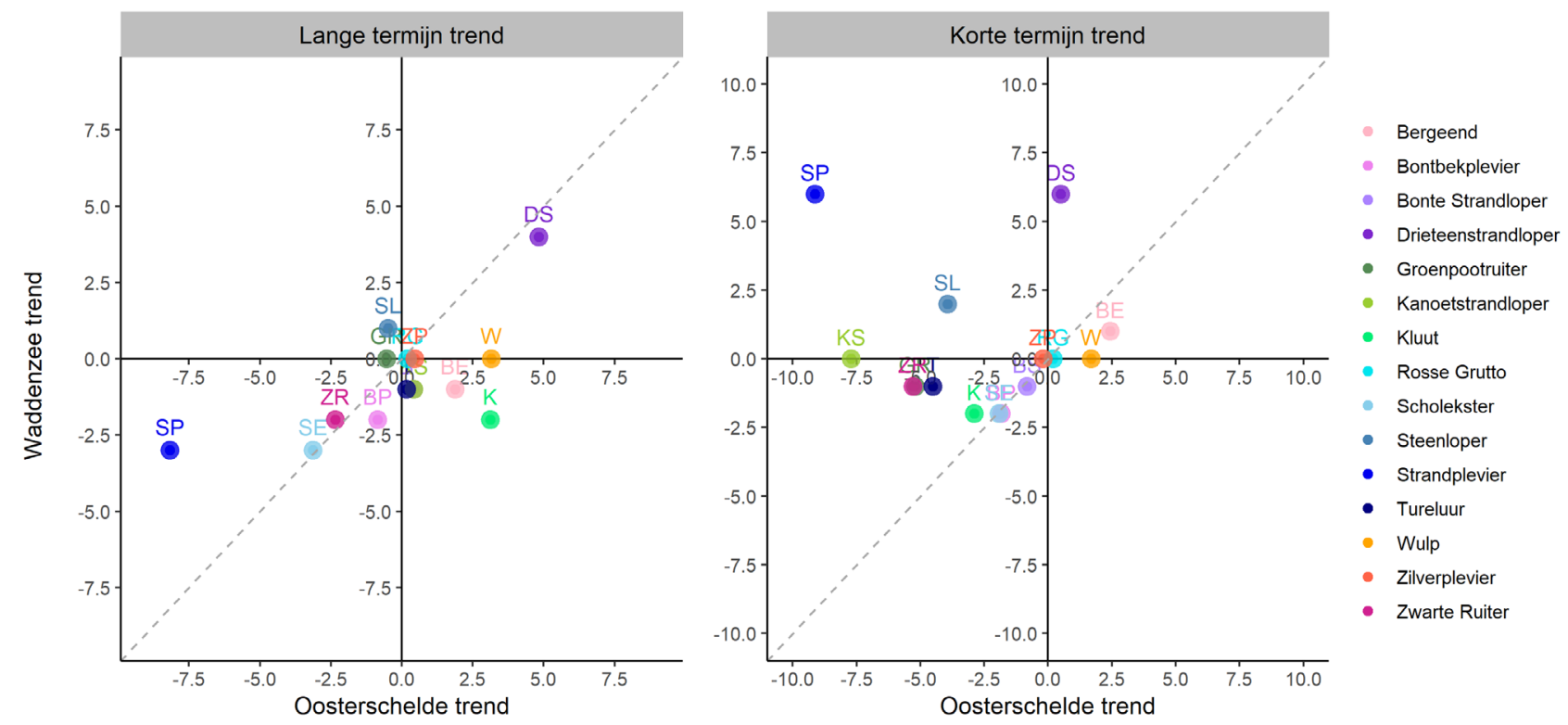

Figuur $40 \quad$ Oosterschelde trends (procentuele verandering) vergeleken met de Waddenzee trends van de geselecteerde soorten. Links lange termijn trends van telseizoen ' $87 /$ ' 88 tot '16/'17 en rechts korte termijn trends van telseizoen '07/'08 voor de Oosterschelde en vanaf telseizoen '08/'09 voor de Waddenzee tot telseizoen '16/'17. Trends zijn berekend met Trendspotter, Waddenzee trends zijn overgenomen uit (Kleefstra et al. 2019). Als punten op de stippellijn liggen is de verandering in de Oosterschelde hetzelfde als in de Waddenzee. Soorten die links van de lijn liggen doen het beter in de Waddenzee, soorten die rechts van de lijn liggen doen het beter in de Oosterschelde.
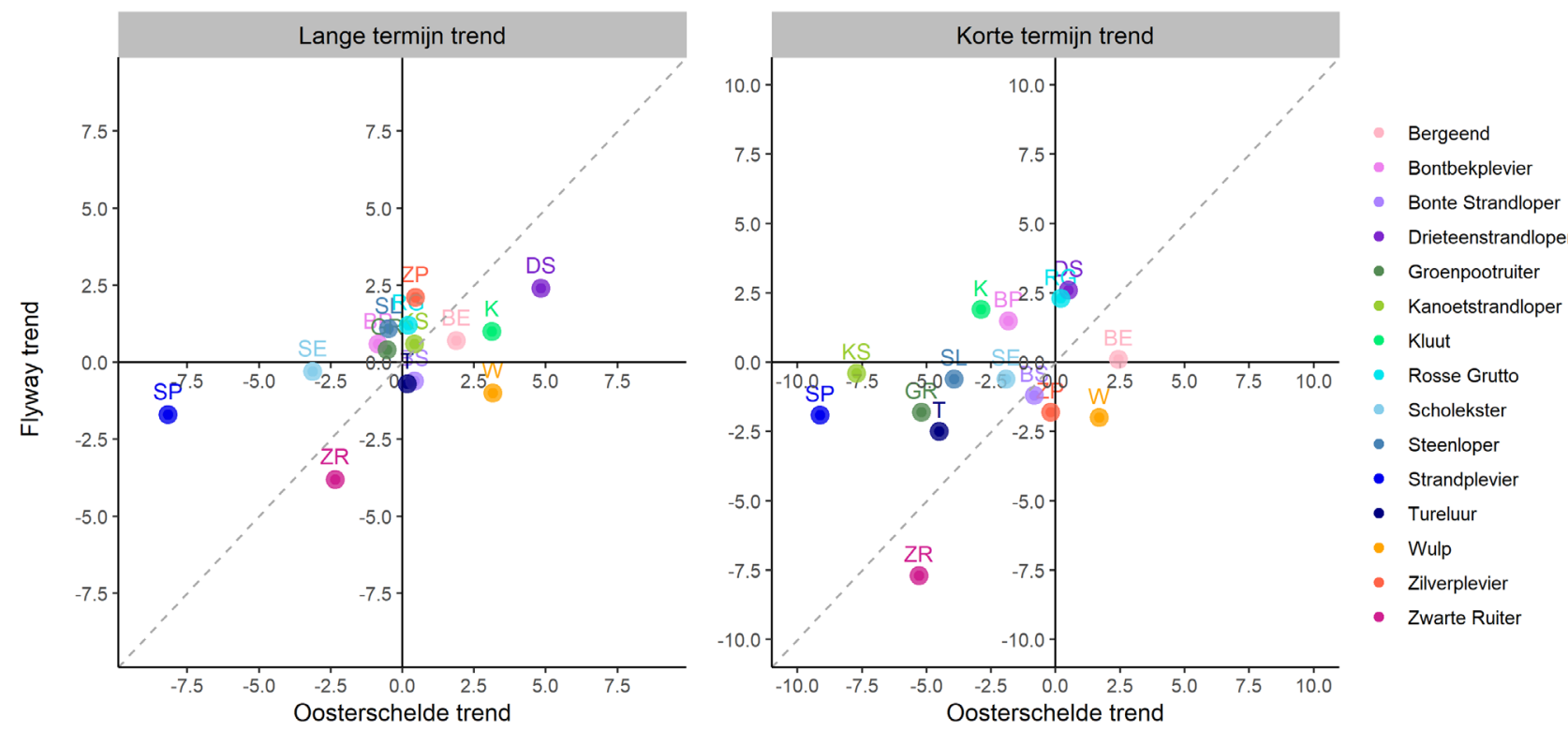

Figuur 41 Oosterschelde trends (procentuele verandering) vergeleken met de flyway trends van de geselecteerde soorten Links de lange termijn trends van telseizoen '87/'88 tot '16/'17 en rechts de korte termijn trends van telseizoen '07/'08 tot '16/'17. Trends zijn berekend met Trendspotter, flyway trends zijn overgenomen uit (van Roomen et al. 2018). Als punten op de stippellijn liggen is de verandering in de Oosterschelde hetzelfde als in de flyway. Soorten die rechts van de lijn liggen doen het beter in de Oosterschelde dan in de hele flyway. 


\section{$3.4 \quad$ Plaatareaal}

Om te bepalen waar de veranderingen in vogelaantallen van bepaalde soorten vandaan komen, dienen de vogeltrends vergeleken te worden met de verandering in het plaatareaal. Een analyse van de aantallen vogels ten opzichte van het plaatareaal is echter buiten het bestek van deze rapportage. We laten hier toch kort zien wat er op dit moment bekend is over de afname van het plaatareaal in de Oosterschelde sinds de vorige studie (Jacobse et al. 2008; Troost and Ysebaert 2011) en wat de voorspellingen zijn.

De vorige rapportage liet zien dat tussen 1990 en 2007 al $6 \mathrm{~km}^{2}$ aan plaatareaal verloren was gegaan door erosie, waarbij de grootste afname in het oostelijk deelgebied was (Troost and Ysebaert 2011). Een latere publicatie over de zandhonger in de Oosterschelde meldt dat op basis van berekeningen

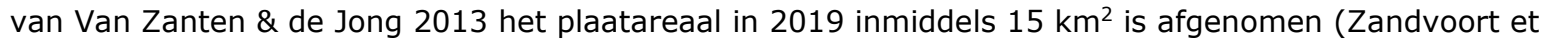
al. 2019).

Dat deze afname aan areaal in de vorige analyse (Troost and Ysebaert 2011) nog niet had geleid tot een afname in steltlopers, komt mogelijk doordat erosie vooral had plaatsgevonden in de hogere delen van de platen. De lager gelegen platen worden door aanvoer van zand van de hogere delen gevoed en nemen daardoor nog niet af. Daarnaast worden de hoger gelegen delen door de erosie lager gelegen platen. De lager gelegen platen bevatten over het algemeen meer bodemdieren van hogere kwaliteit dan de hoger gelegen delen omdat zij langere tijd onder water staan, en zijn daarom profijtelijker voor steltlopers (Troost and Ysebaert 2011). Dit beeld wordt bevestigd door De Ronde et al. (2013). Het areaal aan intergetijdengebied neemt vooral af in gebieden met een droogvalduur van 41-60\% en 61$80 \%$, maar blijft stabieler in lagere delen. In 2010 is het areaal intergetijdengebied dat droogvalt 020\% van de tijd zelfs toegenomen ten opzichte van 1983 (De Ronde et al. 2013). Ook voorspellingen bevestigen de eerder geobserveerde patronen dat de afnames aan areaal waarschijnlijk vooral in de hogere delen zullen gebeuren, terwijl de lagere delen met een droogvalduur van 0-40\% pas later (vanaf 2040-2050) zullen afnemen (De Ronde et al. 2013; Zandvoort et al. 2019).

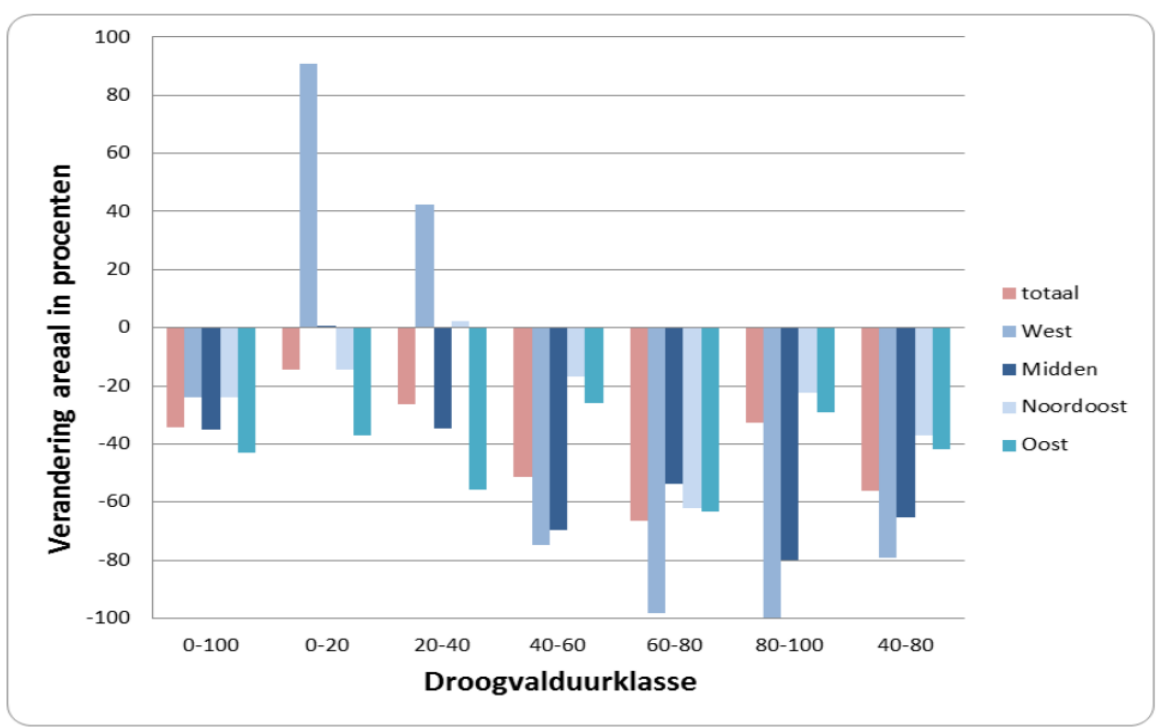

Figuur 42 Voorspelde af- en toename van platen areaal in de Oosterschelde tussen 2010 en 2060 per droogvalklasse en deelgebied overgenomen uit De Ronde et al. (2013), Figuur 3.6. Deelgebied Midden komt overeen met deelgebied Centraal en deelgebied Noordoost met Noord in de huidige rapportage. 
Twee publicaties doen ook voorspellingen hoe het plaatareaal zal veranderen over de tijd (De Ronde et al. 2013; Zandvoort et al. 2019). In de voorspellingen wordt verwacht dat de afname varieert tussen de verschillende deelgebieden, bijvoorbeeld door variatie van golfslag en andere abiotische kenmerken. De snelste afname wordt verwacht in deelgebied Oost, terwijl het plaatareaal in het westelijk en noordelijk deelgebied mogelijk het minst hard afnemen (Figuur 42). De lagere gebieden (met droogval < 40\%) nemen ook het hardst af in Oost, terwijl deze in West juist mogelijk toenemen doordat hoger gelegen gebieden veranderen in lager gelegen gebieden (De Ronde et al. 2013). Het intergetijdengebied dat mogelijk het belangrijkste foerageergebied is voor steltlopers en bergeenden met een droogvalduur van 40-60\% van de tijd, wordt verwacht het hardst af te nemen in deelgebied West (De Ronde et al. 2013; Zandvoort et al. 2019) (Figuur 43). In West is inmiddels wel een zandsuppletie uitgevoerd op de Roggenplaat. Recentere metingen zijn nodig om te bepalen hoe het er nu voorstaat met het plaatareaal, zodat deze vergeleken kunnen worden met de vogeltrends.

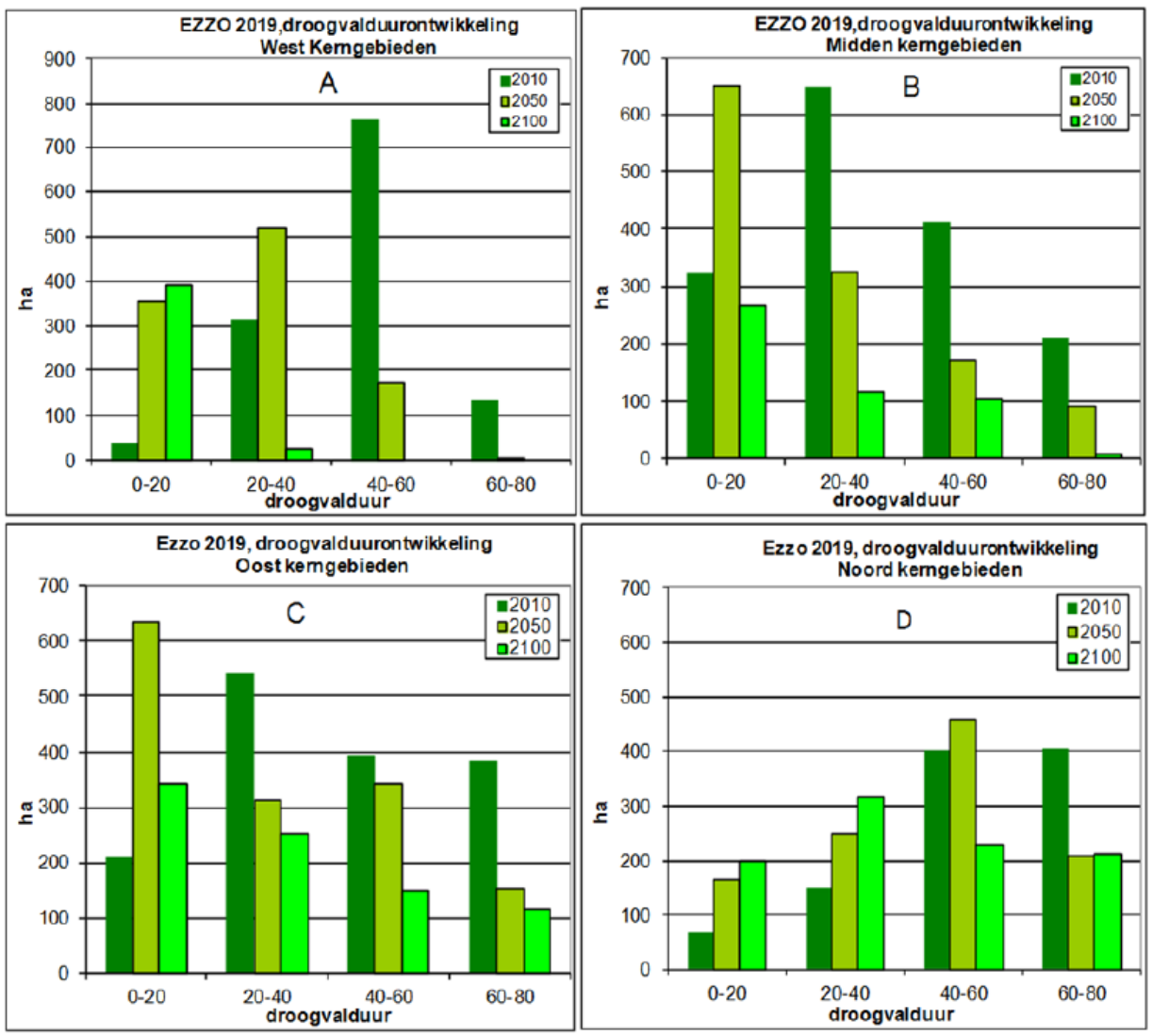

Figuur 43 Voorspelde af- en toename van platareaal in de Oosterschelde tussen 2010 en 2100 per droogvalklasse en deelgebied overgenomen uit Zandvoort et al. (2019), Figuur 2 uit Bijlage 5. Deelgebied Midden komt overeen met deelgebied Centraal in de huidige rapportage. 


\subsection{Voedsel}

Totale dichtheid en biomassa van de bodemdiergemeenschap in de Oosterschelde vertonen grote fluctuaties (Troost and Ysebaert 2011; Duijts et al. 2017; Craeymeersch 2020). De totale dichtheid is in orde van grootte echter niet erg veranderd sinds het begin van de meetperiode (1992) en wordt vooral bepaald door gastropoden (Duijts et al. 2017). Gastropoden zoals wadslakjes zijn belangrijke prooien voor bijvoorbeeld tureluur, zilverplevier, bonte strandloper, steenloper, en bergeend (Tabel 2). De biomassa per vierkante meter neemt sinds 2000 iets af in de Oosterschelde (Duijts et al. 2017). De Bivalven bepalen ongeveer de helft van de biomassa in de bodemdiergemeenschap, gevolgd door Gastropoden (die in aantallen abundanter zijn). Bivalven zoals kokkels, nonnetjes, en mossels zijn belangrijke prooien voor scholeksters en kanoetstrandlopers (Tabel 2).

Een recent overzicht van de bodemdiergemeenschap per deelgebied is te vinden in Creaymeersch et al (2020). Biomassa en dichtheid van Arthropoda, Bivalven, Gastropoden en Annelida verschillen tussen de vier deelgebieden. De grootste dichtheden worden in Oost gevonden. Gastropoden veroorzaken grotendeels de fluctuaties in de dichtheid in Noord, Centraal en Oost. In West wordt de dichtheid vooral bepaald door borstelwormen (Annelida), gevolgd door kreeftachtigen (Arthropoda). Biomassa wordt voornamelijk bepaald door de bivalven, met name de kokkel (Cerastoderma edule). In Noord is de hoogste biomassa per vierkante meter te vinden, maar deze lijkt te zijn afgenomen in de laatste jaren. In Oost heeft er al eerder (begin jaren 2000) een afname van biomassa plaatsgevonden, maar de biomassa lijkt weer iets toe te nemen de laatste jaren. De andere deelgebieden lijken een ongeveer even grote biomassa te hebben, alhoewel er grote fluctuaties zijn over de tijd. In Oost en Noord is de grootste dichtheid gevonden van Gastropoden (voornamelijk wadslakjes), maar deze lijken ook wat te zijn afgenomen de afgelopen jaren. Dichtheden van Annelida zijn vergelijkbaar in de verschillende deelgebieden en lijken iets toe te nemen.

Voor vogelsoorten die bivalvia eten zoals scholekster en kanoet (Tabel 2) daalt het voedselaanbod in deelgebied Noord, het belangrijkste deelgebied wat betreft dichtheden. In Oost was het voedselaanbod voor deze soorten bijna volledig verdwenen wat betreft biomassa, maar lijkt weer iets terug te komen. Voor een wormeneter zoals de rosse grutto (Tabel 2) was het voedselaanbod erg laag begin deze eeuw, maar is nu weer toegenomen. Dit zelfde beeld is te zien voor andere soorten, zoals kluut, zilverplevier, drieteenstrandloper en bonte strandloper waarbij het voedselaanbod met name in Noord en Oost een dip vertoont begin deze eeuw en nu weer iets herstelt is.

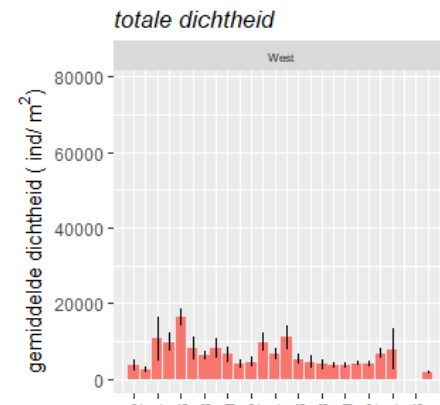

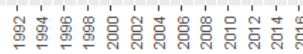

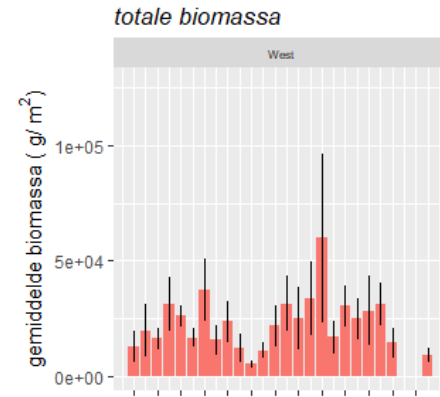

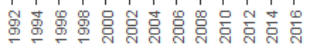
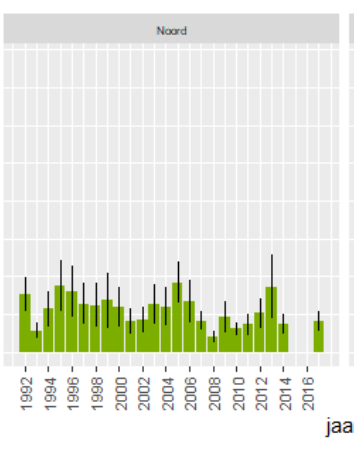

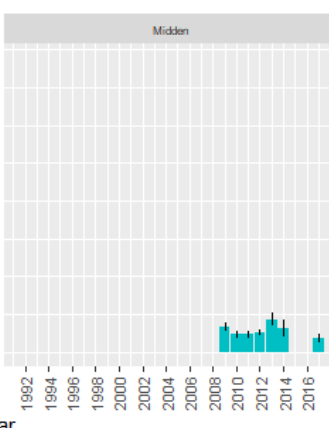
jaar

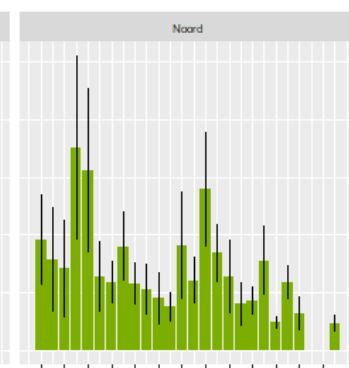

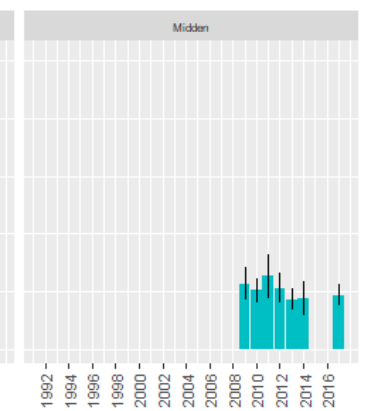

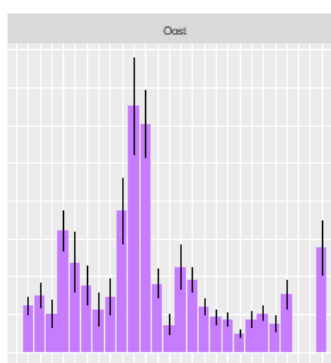

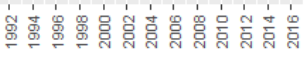

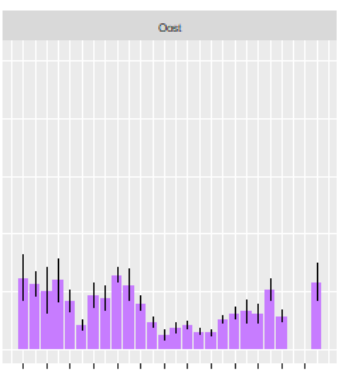

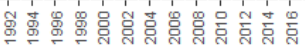

Figuur 44 Gemiddelde dichtheid (aantal per $\mathrm{m}^{2}$ ) en biomassa ( $g r a m$ per $\mathrm{m}^{2}$ ) van bodemdieren (Arthropoda, Bivalven, Gastropoden en Annelida) in de Oosterschelde over de tijd per deelgebied overgenomen uit (Craeymeersch 2020). 


\section{$4 \quad$ Discussie en conclusies}

\subsection{Algemene bevindingen vogeltrends}

In deze rapportage is een overzicht gegeven van de trends van een aantal steltlopers die onder Natura 2000 bescherming vallen in de Oosterschelde over de periode 1987-2017/2018. De directe aanleiding van dit onderzoek is het afnemende plaatareaal in de Oosterschelde door zandhonger. De verwachting is daarom dat de aantallen steltlopers ook zullen afnemen, omdat hun foerageergebied kleiner wordt. Trends over de hele Oosterschelde en vier deelgebieden zijn geanalyseerd voor de soorten bontbekplevier, bonte strandloper, drieteenstrandloper, groenpootruiter, kanoetstrandloper, kluut, rosse grutto, scholekster, steenloper, strandplevier, tureluur, wulp, zilverplevier en zwarte ruiter. Bij deze analyse is ook de bergeend meegenomen, die ook veelvuldig gebruik maakt van de platen. In een eerdere rapportage over de vogeltrends in de Oosterschelde, werd nog geen effect van het afnemende areaal op vogelaantallen geconstateerd (Troost and Ysebaert 2011). De voorliggende rapportage presenteert een update van de trends van steltlopers en bergeend zo'n tien jaar later.

\subsubsection{Oosterschelde totaal}

Gemeten over de hele Oosterschelde, zien we geen significante trend in de totale aantallen steltlopers en bergeenden. Er lijkt echter een lichte daling te zijn ingezet in het totaal aantal vogels (Figuur 4). Over de tijd zijn de aantallen vooral in de herfst afgenomen (Figuur 5). De daling van aantallen in het najaar wordt met name veroorzaakt door de grote afname van scholeksters in die periode. Net zoals de eerdere rapportage, zijn er soorten die toenemen, afnemen en gelijk blijven. Echter, zijn er vergeleken met de vorige analyses, minder soorten toegenomen over de tijd. De kanoetstrandloper en tureluur namen 10 jaar geleden nog toe in aantallen, maar zijn het afgelopen decennium weer afgenomen, waardoor aantallen weer vergelijkbaar zijn met het begin van de telperiode (Figuur 6). Voor de meest recente periode (vanaf 2010-2011 tot 2017/2018) is alleen de bergeend significant toegenomen. Vijf soorten (strandplevier, scholekster, zwarte ruiter, kanoetstrandloper en tureluur) zijn significant afgenomen en de rest van de soorten zijn stabiel gebleven of hebben een onzekere trend. Ten opzichte van de vorige analyse lijkt er dus een afvlakking van groei of (lichte) daling te zijn ingezet voor de meeste soorten. $\mathrm{Er}$ is op het eerste gezicht geen duidelijke relatie met voedselkeuze of migratiepatronen tussen soorten die toe- of afnemen.

\subsubsection{Oosterschelde per deelgebied}

Trends verschillen over de deelgebieden. Totale aantallen geselecteerde vogels nemen significant af in Oost. In Centraal en West zijn de aantallen de laatste jaren stabiel, net als in Noord. In Noord lijkt echter ook een lichte daling te zijn ingezet in de laatste twee telseizoenen. Net als voor de hele Oosterschelde, zijn er minder soorten die zijn toegenomen in de meest recente periode (vanaf telseizoen 2010-2011) vergeleken met de hele meetperiode vanaf telperiode 1987-1988. Wanneer we kijken naar de totale aantal toe- en afnames over alle deelgebieden, zagen we over de lange termijn bijna drie keer zoveel toe als afnames. Over de korte termijn zijn er juist iets meer afnames dan toenames. In de lange termijn vergelijking (vanaf telperiode 1987-1988) namen de meeste soorten af in deelgebied Oost, in de korte termijn vergelijking vanaf telperiode 2010-2011 kwamen de meeste afnames in West en Oost voor.

Tellingen worden normaal gesproken bijgeschat (imputen) om missende telgebiedjes te compenseren. Voor de analyse van seizoensgemiddelden per deelgebied is echter gebruik gemaakt van tellingen die niet zijn gecorrigeerd, omdat de bijgeschatte aantallen nog niet beschikbaar zijn. Ook hebben we alleen de tellingen van zes maanden gebruikt, omdat in de andere maanden niet meer de gehele Oosterschelde systematisch wordt geteld. Ongecorrigeerde en gecorrigeerde tellingen over de hele Oosterschelde komen echter goed overeen. Daarnaast zijn telgebiedjes maar zelden gemist in de zes volledig getelde maanden. Wij denken daarom dat de gebruikte getallen betrouwbaar zijn en een goed beeld geven van vogeltrends in het gebied. Wel vallen er meer getelde maanden in de winter 
vergeleken met de andere jaargetijden. Voor soorten waarbij de piek vooral in de niet-getelde maanden valt, zoals de zwarte ruiter en bontbekplevier (doortrekpiek grotendeels in september en oktober) zouden belangrijke verschuivingen gemist kunnen worden door deze manier van tellen en zijn de gepresenteerde patronen mogelijk minder betrouwbaar.

\subsubsection{Oosterschelde ten opzichte van de Waddenzee en flyway}

Toe- of afnames van vogels zijn vaak lastig te verklaren omdat vogels afhankelijk zijn van meer dan één gebied. Zo kan de afname van een soort ook worden veroorzaakt doordat condities in een gebied elders verslechterd zijn. Vanwege deze reden hebben we de lange- en korte-termijntrends van de geselecteerde soorten vergeleken met trends in de Waddenzee en de flywaypopulatie. Een interessante bevinding hier is dat trends in de Oosterschelde op de lange termijn min of meer overeen komen met trends in de Waddenzee en de flywaypopulatie, met uitzondering van de wulp die het op lange termijn beter doet vergeleken met Waddenzee en flywaypopulatie. Echter, op de korte termijn zijn de trends in de Oosterschelde negatiever vergeleken met de Waddenzee en de flywaypopulatie. De steenloper en kanoetstrandloper doen het slechter in de Oosterschelde voor zowel de Waddenzee als in de flywaypopulatie. Verder zijn de trends voor strandplevier, zwarte ruiter, tureluur en drieteenstrandloper negatiever in de Oosterschelde vergeleken met de Waddenzee en zijn de trends voor groenpootruiter, kluut en bontbekplevier slechter dan in de flywaypopulatie. De negatievere korte-termijnontwikkelingen voor deze soorten suggereren dat de condities in de Oosterschelde recentelijk verslechterd zijn.

Een kanttekening bij deze vergelijking is dat de data die we gebruikt hebben voor de flywaytrends onderscheid heeft gemaakt tussen verschillende ondersoorten en flyway populaties, terwijl er bij de tellingen geen onderscheid kan worden gemaakt. Sommige ondersoorten verschillen nogal in trends omdat ze gebruik maken van andere gebieden. Met behulp van de seizoenspatronen en de literatuur hebben we echter een goede keuze kunnen maken voor de ondersoort of flywaypopulatie die zeer waarschijnlijk de populatie in de Oosterschelde representeert. Een uitzondering hierop is de tureluur, waarbij lastig te bepalen is welke ondersoort het meeste in de Oosterschelde te vinden is.

\subsection{Vogeltrends en plaatareaal}

Het grootste areaal aan platen in de vorige rapportage was in de gebieden Centraal en Oost, en het kleinste areaal in West en Noord (Troost and Ysebaert 2011). De meeste vogels worden over het algemeen ook geteld in de gebieden met het grootste areaal aan platen; Centraal en Oost, alhoewel het aantal vogels in Oost aan het afnemen zijn en vergelijkbaar met deelgebied West.

De afname in het plaatareaal erodeerde in de periode tussen 1987 tot 2009 het hardst in deelgebied Oost (Troost and Ysebaert 2011). Ook voorspellingen voor 2060 laten zien dat plaatareaal in dit deelgebied mogelijk het hardst aan het afnemen is, gevolgd door deelgebied Noord (Troost and Ysebaert 2011; De Ronde et al. 2013). In deze rapportage laten we zien dat in deelgebied Oost de vogelaantallen significant afnemen over de hele periode, wat overeen komt met de voorspelde afname in plaatareaal in het deelgebied (Figuur 7). In Noord zijn de aantallen nog stabiel, maar er lijkt hier een lichte afname te zijn ingezet in de laatste twee telseizoenen.

Echter, waarschijnlijk is niet het totaal aan plaatareaal belangrijk voor vogels, maar gedeeltes van de platen die ongeveer 40 tot $60 \%$ van de tijd droogvallen. Deze droogvalklasse neemt het snelst af in deelgebied West (De Ronde et al. 2013). In deze rapportage zien we nog geen afname in het totaal aantal vogels in dit deelgebied. Wel nemen drie vogelsoorten significant af in deelgebied West; de strandplevier, scholekster en kanoetstrandloper. Daarentegen zijn de rosse grutto, zilverplevier en bergeend toegenomen in dit deelgebied. Verschillen tussen soorten in voorkeuren voor plekken op het wad of voedselbeschikbaarheid zouden hier een rol kunnen spelen (van de Kam 1969). In deelgebied West is het areaal aan platen met een korte droogvalduur $(<40 \%)$ waarschijnlijk toegenomen, door erosie op de hoger gelegen delen (De Ronde et al. 2013). Concluderend zijn patronen van plaatareaal en vogelaantallen en soorten niet eenduidig en dienen recentere metingen aan beschikbaar plaatareaal in het veld in relatie tot vogelaantallen geanalyseerd te worden. 


\subsection{Vogeltrends en benthos}

Naast het plaatareaal, is het prooiaanbod zoals dichtheid en biomassa per vierkante meter van bepaalde soorten van belang voor steltlopers. Dichtheden van prooidieren over de hele Oosterschelde kunnen enorm fluctueren over de tijd maar zijn in ordegrootte de laatste jaren niet erg veranderd. De biomassa is iets afgenomen over de tijd.

Deelgebieden verschillen in dichtheid en biomassa bodemdieren met ook hier grote fluctuaties tussen jaren. De grootste dichtheden zijn te vinden in deelgebied Oost en de hoogste biomassa in deelgebied Noord. Wat betreft het laatste decennia lijkt de biomassa in deelgebied Noord de laatste jaren gemiddeld iets lager te zijn. Biomassa wordt voor een groot deel bepaald door schelpdieren, wat belangrijk voedsel is voor de scholekster en kanoetstrandloper. Deze soorten nemen beiden significant af in de hele Oosterschelde, en de scholekster ook specifiek in deelgebied Noord. De kortetermijntrend in kanoetstrandlopers is negatiever in de Oosterschelde vergeleken met de trend in de Waddenzee en de flywaypopulatie. De afname van scholeksters speelt vooral in het najaar. Mogelijk is de voedselconditie specifiek in die periode verslechterd.

Over het algemeen fluctueert het voedselaanbod, maar is alleen voor schelpdiereters duidelijk slechter geworden in Noord (in biomassa per vierkante meter) sinds het begin van de meetperiode. Echter, als het totale areaal aan foerageergebied significant is afgenomen, kan dit natuurlijk wel consequenties hebben voor het voedselaanbod voor alle steltlopers. Een analyse van vogeltrends waarbij het totale aanbod aan prooidieren berekend wordt m.b.v. plaatareaal worden meegenomen zouden meer inzichten kunnen bieden, maar vallen buiten de scope van deze rapportage.

\subsection{Vogeltrends en overige factoren}

Verstoringen op hoogwatervluchtplaatsen of platen en weerscondities kunnen afnames veroorzaken of de gevolgen van verminderd foerageergebied versterken. Met name in de winter, als vogels een hoge energetische behoefte hebben of in de migratietijd als vogels in korte tijd moeten opvetten moeten vogels hun voedsel zoeken in de beperkte tijd dat de platen voor hen beschikbaar zijn. Slikgebieden die dicht langs de dijken liggen, worden langzamerhand relatief belangrijker vanwege de zandhonger op de platen. Hierdoor worden de negatieve effecten van verstoringen langs de kust belangijker. Ook is de toegankelijkheid voor recreanten afgelopen tijd (10-15 jaar) verbeterd door openstellen van buitendijkse onderhoudswegen en de aanleg van fietspaden. Ook zijn er nieuwe vakantieparken aangelegd die mogelijk voor meer verstoring zorgen. Verstoringen vinden bijvoorbeeld plaats in de vorm van wandelaars al dan niet met loslopende honden. Op Neeltje Jans zorgen honden voor grote verstoring onder foeragerende watervogels en watervogels die daar tijdens hoogwater rusten op de hoogwatervluchtplaatsen. Ook vinden verstoringen door "oogsten uit de natuur" op grote schaal plaats. Met name het oogsten van schelpdieren door particulieren aan de Grevelingendam (Plaat van Oude Tonge) levert veel en langdurige verstoringen op. Ook neemt de laatste jaren het betreden van afgesloten slikgebieden zoals de Slikken van Viane toe; tijdens meerdere maandelijkse tellingen werd hier betreding door recreanten vastgesteld. Toenemende recreatiedruk is waarschijnlijk, naast voedselbeschikbaarheid, een belangrijke sturende factor in vogelaantallen, maar precieze verstoringsdruk is nog niet in kaart gebracht.

Weerscondities kunnen ook een rol spelen in de aantallen vogels. In het verleden hebben heftige winters gezorgd voor bevriezing van de platen, waardoor steltlopers nauwelijks konden foerageren. Met name de winters van 1995/1996 en 1996/1997 waren koud en hebben geleid tot sterfte van steltlopers (Troost and Ysebaert 2011, Bijlage 2). De laatste jaren zijn ook te warme condities een mogelijke bedreiging voor steltlopers. Zo trad er in 2018 massale kokkelsterfte op, waarschijnlijk doordat droogvallende platen te warm werden voor kokkels (Suykerbuyk et al. 2020). Gezien de stijgende temperaturen, is de kans groot dat dit soort condities vaker voor gaan komen. 


\subsection{Conclusie}

Concluderend zien we een afvlakking of zelfs afname van aantallen voor de meeste soorten in de Oosterschelde sinds de vorige rapportage (2010) waarbij vogeltrends geanalyseerd werden. Dit zou kunnen wijzen op een effect van het afnemende plaatareaal. Deze hypothese wordt versterkt doordat de korte-termijn trends voor een aantal vogelsoorten negatiever zijn geworden vergeleken met de Waddenzee- en flywaypopulatietrends. Voor sommige prooidieren is in sommige deelgebieden (met name Noord) een dalende trend te zien. Ook zou toegenomen recreatie en hiermee verstoring een rol kunnen spelen. Een analyse waarbij recent gemeten plaatareaal, droogvalduur en aanwezige bodemdieren meegenomen worden is daarom noodzakelijk en zal meer inzichten kunnen bieden over de oorzaak van de verslechterde vogeltrends. Eventueel zou hierbij gedacht kunnen worden aan een modelmatige analyse zoals WEBTICS (Rappoldt et al. 2004). In dit model is energiebehoefte van in dit geval scholeksters gecombineerd met oppervlakte van platen, droogval en hoogte, en dichtheid, biomassa en soort prooien.

Daarnaast neemt plaatareaal met een korte droogvalduur toe doordat erosie plaatsvindt op hogere delen van de platen. Sommige soorten zouden op korte termijn misschien kunnen profiteren van deze delen van de platen. Hierbij is kennis nodig over hoe verschillende soorten steltlopers de platen gebruiken over het getij door observaties of zenderstudies, vergelijkbaar met tellingen die in de Westerschelde plaats vinden (Boudewijn et al. 2019). In deelgebied West vinden nu laagwatertellingen plaats op de Roggenplaat in het kader van de zandsuppleties daar, die al eerste inzichten zullen bieden. 


\section{$5 \quad$ Kwaliteitsborging}

Wageningen Marine Research beschikt over een ISO 9001:2015 gecertificeerd kwaliteitsmanagementsysteem. Dit certificaat is geldig tot 15 december 2021. De organisatie is gecertificeerd sinds 27 februari 2001. De certificering is uitgevoerd door DNV GL. 


\section{Literatuur}

Arts FA, Hoekstein MSJ, Lilipaly S j., van Straalen KD, Sluijter M, Wolf PA. 2019. Watervogels en zeezoogdieren in de Zoute Delta 2017/2018. Deltamilieu Proj.:122.

Boudewijn TJ, Zwerver J, Sluijter M, Hoekstein MSJ, Wolf PA, Lilipaly SJ, van Straalen KD, Arts FA, Beuker D. 2019. Vogeltellingen met afgaand water in de Westerschelde. Voortgangsrapportage september 2018 augustus 2019. Bur Waardenbg Rapp Bur Waardenburg, Culemborg.

Craeymeersch J. 2020. Bodemdiergemeenschap Oosterschelde.

Duijts O, Jagt HA Van Der, Moorsel G Van, Kruijt DB, Japink M, Middelveld RP. 2017. Macrozoöbenthosbemonstering in de Zoute Rijkswateren, Hoofdrapport, MWTL 2017.

Ens BJ, Meer J van der, Troost K, Winden E van, Schekkerman H, Rappoldt K. 2016. Monitoring van het voor vogels oogstbare voedselaanbod in de kombergingen van het Pinkegat en Zoutkamperlaag : rapportage $t / m$ monitoringjaar 2018. https://edepot.wur.nl/476732.

del Hoyo J, Elliott A, Sargatal J. 1996. Handbook of the birds of the world. Volume 3.

Jacobse J, Van der Zel M, Arnold E, Hofstad E. 2008. Toekomstprognose ontwikkeling intergetijdengebied Oosterschelde. Doorvertaling naar effecten op veiligheid en natuurwaarden.

van de Kam J. 1969. Op de grens van land en zee. Derde druk. Helmond.

Kleefstra R, Hornman M, Bregnballe T, Frikke J, Günther K, Hällterlein B, Körber P, Ludwig J, Scheiffarth G. 2019. Trends of Migratory and Wintering Waterbirds in the Wadden Sea 1987 / 1988- 2016/2017. Wadden Sea Ecosyst.(39):1-68.

Meininger P, Arts F. 1997. De Strandplevier Charadrius alexandrinus als broedvogel in Nederland in de 20e eeuw. Limosa. 70:41-60.

Meininger PL, Baptist HJM, Slob GJ. 1984. Vogeltellingen in het Deltagebied in 1975/76-1979/80.

Meininger PL, Baptist HJM, Slob GJ. 1985. Vogeltellingen in het zuidelijk Deltagebied in 1980/81-1983/84.

Meininger PL, van Haperen AMM. 1988. Vogeltellingen in het zuidelijk Deltagebied in 1974/85-1986/87.

Rijkswaterstaat nota GWAO-881010/Min Landbouw Viss.

Ministerie van Infrastrucuur en Milieu, Rijkswaterstaat. 2016. Natura 2000 Deltawateren - Oosterschelde Beheerplan 2016-2022.

Rappoldt C, Ens BJ, Berrevoets CM, Geurts van Kessel AJM, Bult TP, Dijkman EM. 2003. Scholeksters en hun voedsel in de Oosterschelde.

Rappoldt C, Ens BJ, Kersten M, Dijkman EM. 2004. Wader energy balance \& tidal cycle simulator WEBTICS. :95. http://library.wur.nl/WebQuery/clc/1719233.

De Ronde JG, Mulder JPM, Van Duren LA, Ysebaert TJW. 2013. Eindadvies ANT Oosterschelde.

van Roomen M, Nagy S, Citegetse G, Schekkerman H. 2018. East Atlantic Flyway Assessment 2017: the status of coastal waterbird populations and their sites.

Schaminée JHJ, Janssen JAM, Kwak R, Litjens GJJM, Mulder JPM, Roels B, Smith SR, Walles B, van Winden A, Winter HV, et al. 2019. Biodiversiteit in de Zuidwestelijke Delta.

Soldaat L, Visser H, Roomen M, Strien A. 2007. Smoothing and trend detection in waterbird monitoring data using structural time-series analysis and the Kalman filter. J Ornithol. 148(SUPLL. 2):351-357.

doi:10.1007/s10336-007-0176-7.

Strucker R, Arts F, Lilipaly S. 2010. Watervogels in en zeezoogdieren in de Zoute Delta 2008/2009. Strucker RCW, Arts F a, Lilipaly S. 2008. Watervogels en zeezoogdieren in de Zoute Delta 2009/2010. Suykerbuyk W, Tangelder M, Walles B. 2020. Oosterschelde Hittestress op de intergetijdenplaten van de Oosterschelde.

Troost K, Ysebaert T. 2011. ANT Oosterschelde: Long-term trends of waders and their dependence on intertidal foraging grounds.

Visser H. 2004. Estimation and detection of flexible trends. Atmos Environ. 38(25):4135-4145.

doi:10.1016/j.atmosenv.2004.04.014.

Zandvoort M, Van der Zee E, Vuik V. 2019. De effecten van Zeespiegelstijging en Zandhonger op de Oosterschelde. (December): 108.

van Zanten E, Adriaanse L. 2008. Verminderd getij. Verkenning naar mogelijke maatregelen om het verlies van platen, slikken en schorren in de Oosterschelde te beperken. Rapport RWS/...Rijkswaterstaat Zeeland, Middelburg. http://scholar.google.com/scholar?hl=en\&btnG=Search\&q=intitle:Verminderd+getij\# 2 . 


\section{Verantwoording}

Rapport C120/20

Projectnummer: 4318100312

Dit rapport is met grote zorgvuldigheid tot stand gekomen. De wetenschappelijke kwaliteit is intern getoetst door een collega-onderzoeker en het verantwoordelijk lid van het managementteam van Wageningen Marine Research

Akkoord:

J.A. Craeymeersch

Onderzoeker

Handtekening:

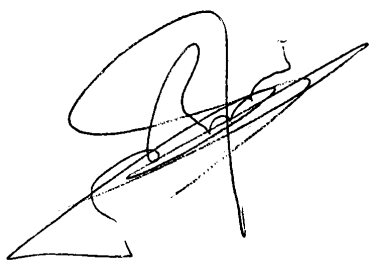

Datum:

23 maart 2021

Akkoord:

J. Asjes

Manager integratie

Handtekening:

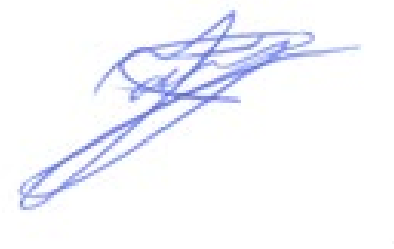

Datum:

23 maart 2021 


\section{Bijlage 1 Totale aantal vogels}

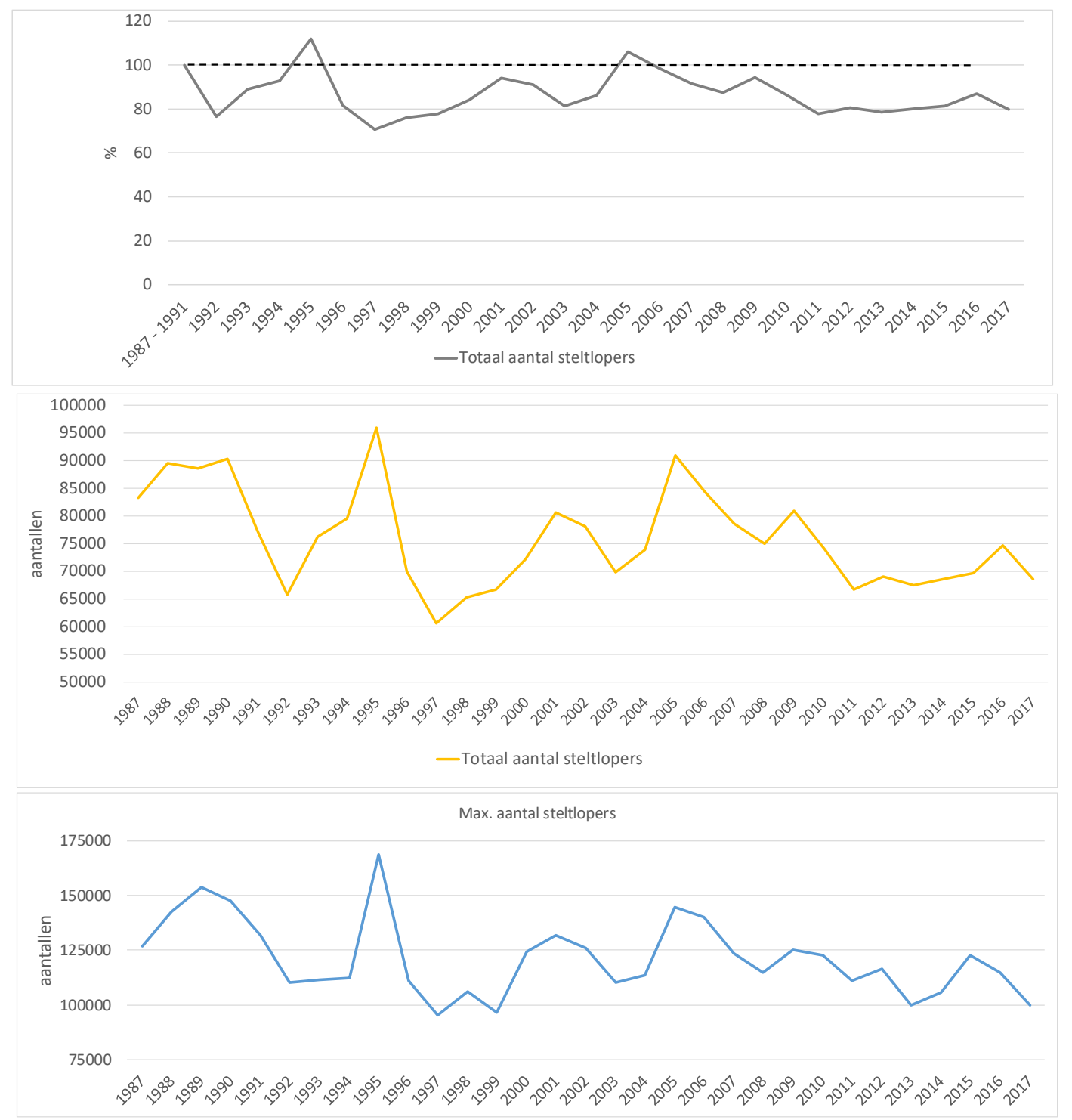

Figuur 45. Procentueel aantal steltlopers in de Oosterschelde t.o.v. de telperiode 1987 - 1911 (=100\%). Midden: seizoensgemiddelde aantallen in de periode $1987-2017$. Onder: maximale aantallen in de periode 1987 - 2007. 


\section{Bijlage 2 Strenge winters}

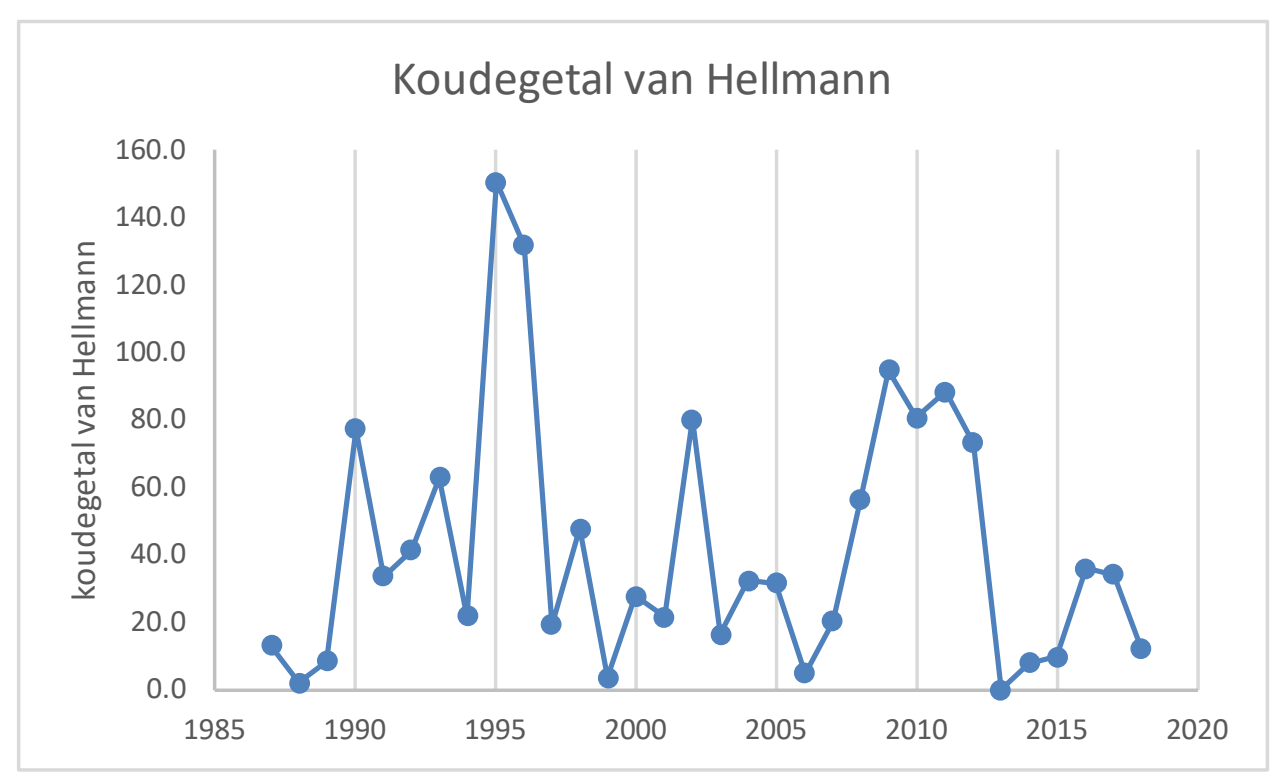




\section{Bijlage 3 Procentuele verloop geselecteerde soorten over de seizoenen}
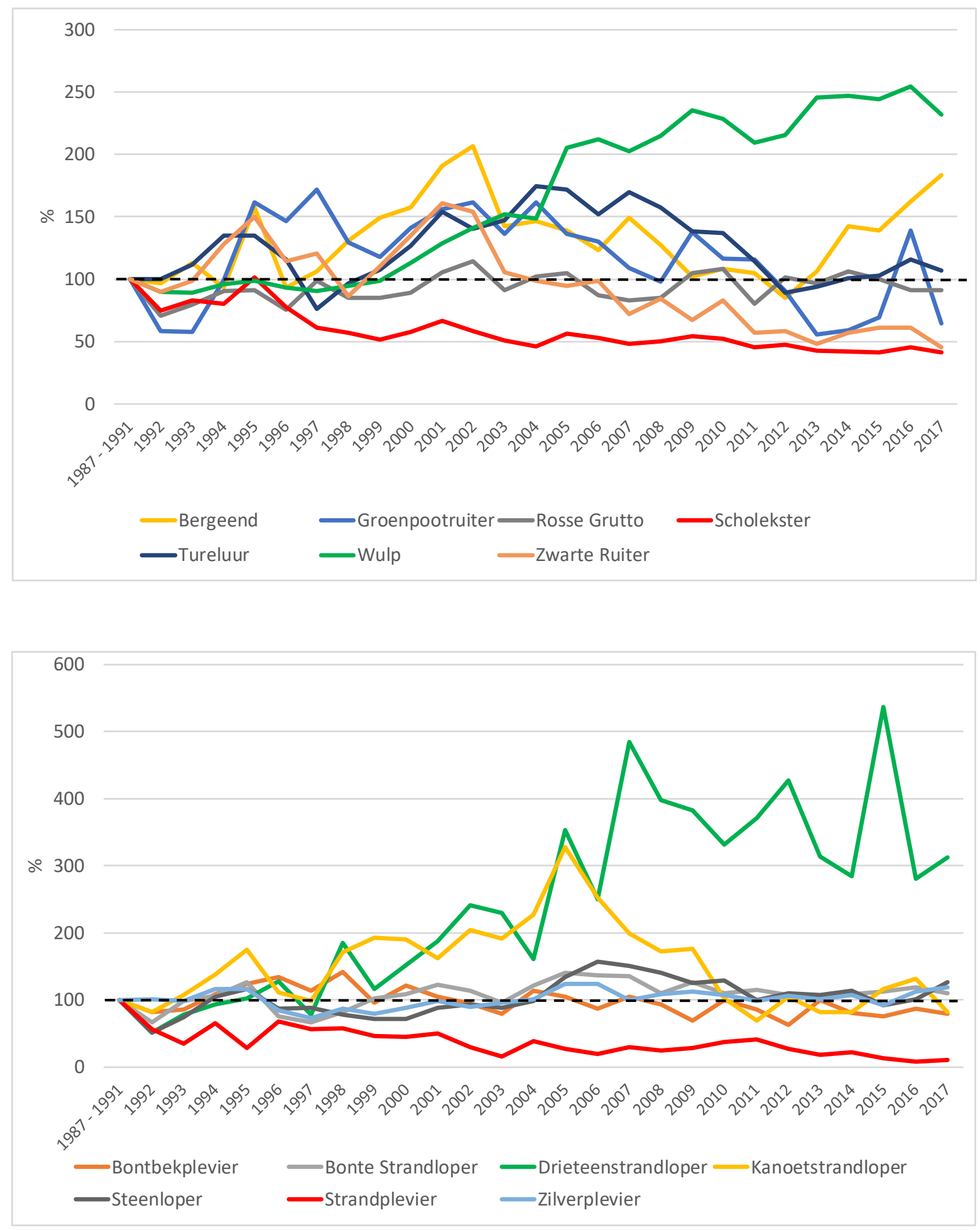


\section{Bijlage 4 Trend vogelsoorten Oosterschelde}

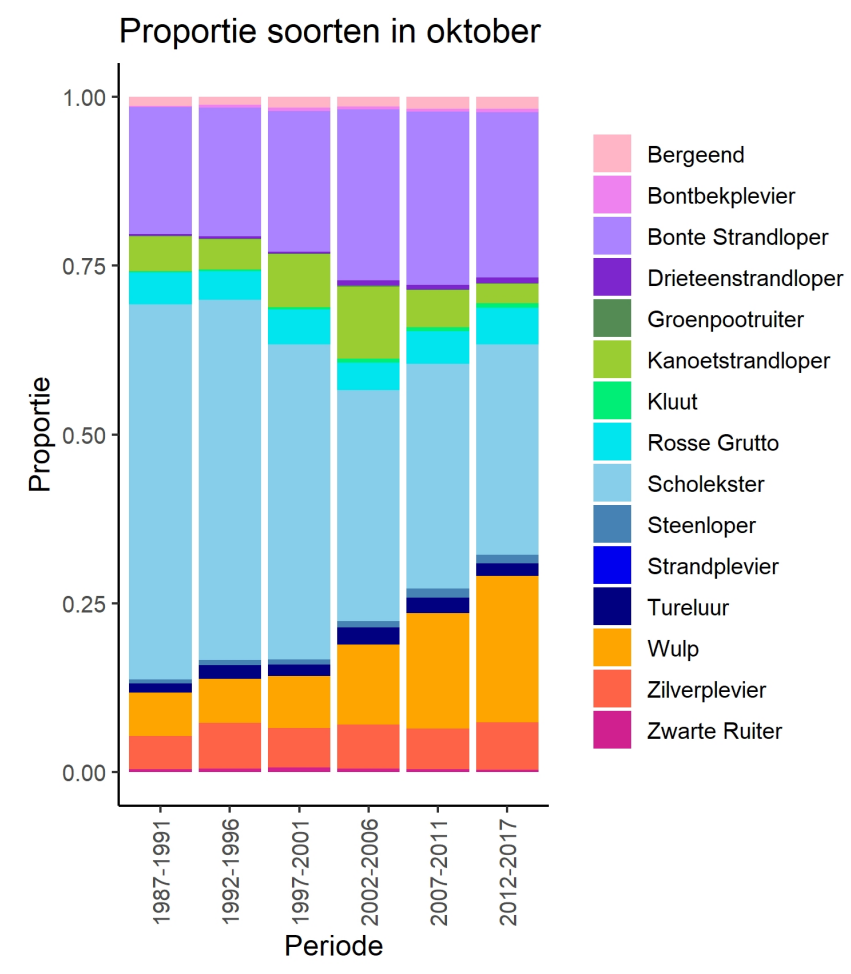



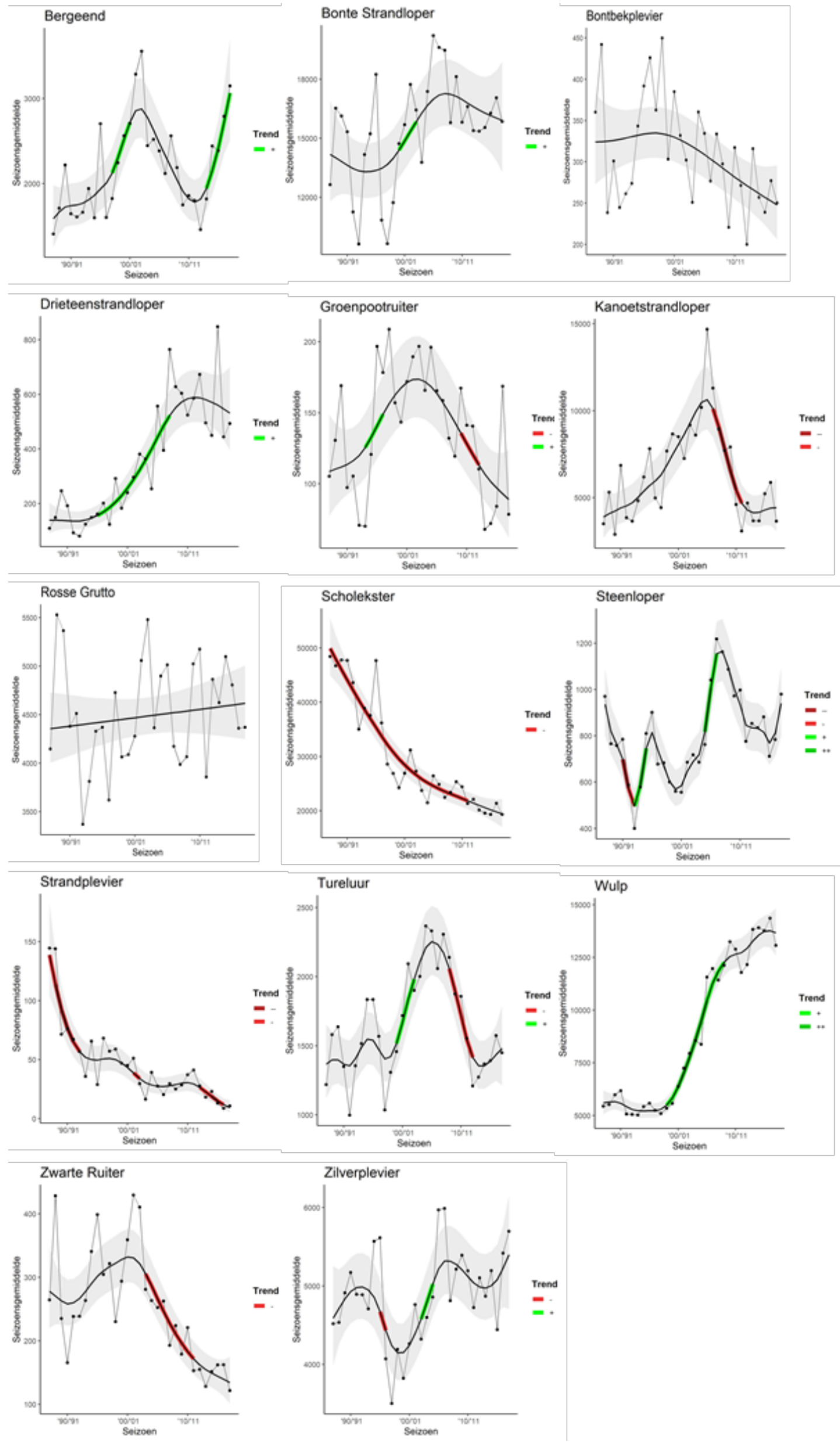


\section{Bijlage 5 Trends Oosterschelde vergeleken met Waddenzee en flyway}

Tabel 4 Jaarlijkse procentuele trend per jaar ten opzichte van Flyway en Waddenzee (van Roomen et al. 2018; Kleefstra et al. 2019)

Soorten in volgorde van grootste afname naar grootste toename gebaseerd op Figuur 9

\begin{tabular}{|c|c|c|c|c|c|c|}
\hline Soort & Flyway & Waddenzee & Oosterschelde & Flyway & Waddenzee & Oosterschelde \\
\hline & $\% / y ~ L$ & & \%/y L & $\% /$ y s & & \\
\hline Strandplevier & -1.7 & -3.0 & -8.2 & -1.9 & 6.0 & -9.1 \\
\hline Scholekster & -0.3 & -3.0 & -3.1 & -0.6 & -2.0 & -1.9 \\
\hline Zwarte ruiter & -3.8 & -2.0 & -2.4 & -7.7 & -1.0 & -5.3 \\
\hline Groenpootruiter & 0.4 & 0.0 & -0.5 & -1.8 & -1.0 & -5.2 \\
\hline Bontbekplevier hiaticula & 0.6 & -2.0 & -0.9 & 1.5 & -2.0 & -1.8 \\
\hline Rosse grutto lapponica & 1.2 & 0.0 & 0.2 & 2.3 & 0.0 & 0.2 \\
\hline Rosse grutto taymyrensis & -2.2 & & & -2.9 & & \\
\hline $\begin{array}{l}\text { Kanoetstrandloper } \\
\text { islandica }\end{array}$ & 0.6 & -1.0 & 0.4 & -0.4 & 0.0 & -7.7 \\
\hline Kanoetstrandloper canutus & -1.3 & & & -6.5 & & \\
\hline Tureluur robusta b & -0.7 & -1.0 & 0.2 & -2.5 & -1.0 & -4.5 \\
\hline $\begin{array}{l}\text { Tureluur totanus } b \\
U K, I R, N W E U\end{array}$ & 0.0 & & & -0.6 & & \\
\hline Zilverplevier & 2.1 & 0.0 & 0.4 & -1.8 & 0.0 & -0.2 \\
\hline Steenloper b Nearc & 1.1 & 1.0 & -0.5 & -0.6 & 2.0 & -3.9 \\
\hline Bonte strandloper alpina & -0.6 & -1.0 & 0.4 & -1.2 & -1.0 & -0.8 \\
\hline Bergeend & 0.7 & -1.0 & 1.9 & 0.1 & 1.0 & 2.4 \\
\hline Kluut & 1.0 & -2.0 & 3.1 & 1.9 & -2.0 & -2.9 \\
\hline Wulp arquata $b$ & -1.0 & 0.0 & 3.1 & -2.0 & 0.0 & 1.7 \\
\hline $\begin{array}{l}\text { Drieteenstrandloper w Eu,w- } \\
\text { Af }\end{array}$ & 2.4 & 4.0 & 4.8 & 2.6 & 6.0 & 0.5 \\
\hline
\end{tabular}

$\mathrm{S}=$ korte termijn trend berekening van '07-'08 tm '16-'17, L = lange termijn trend berekening van '87-'88 tm '16-'17. De flyway-trends zijn berekend voor verschillende ondersoorten, de dikgedrukte ondersoort is gebruikt in de vergelijking met de Oosterschelde. Voor de Waddenzee en Oosterschelde zijn trends gebruikt waar geen onderscheid is gemaakt tussen ondersoorten 
Wageningen Marine Research

$\mathrm{T}:+31(0) 317487000$

E: marine-research@wur.nl

www.wur.nl/marine-research

Bezoekers adres:

- Ankerpark 271781 AG Den Helder

- Korringaweg 7, 4401 NT Yerseke

- Haringkade 1, 1976 CP IJmuiden
Wageningen Marine Research levert met kennis, onafhankelijk wetenschappelijk onderzoek en advies een wezenlijke bijdrage aan een duurzamer, zorgvuldiger beheer, gebruik en bescherming van de natuurlijke rijkdommen in zee-, kust- en zoetwatergebieden.
Wageningen Marine Research is onderdeel van Wageningen University \& Research. Wageningen University \& Research is het samenwerkingsverband tussen Wageningen University en Stichting Wageningen Research en heeft als missie: 'To explore the potential of nature to improve the quality of life' 